\title{
Hydrologic Conditions at the Idaho National Engineering Laboratory, Idaho-Emphasis: 1974-1978
}

By Jack T. Barraclough, Barney D. Lewis, and Rodger G. Jensen

Prepared in cooperation with the U.S. Department of Energy 


\title{
UNITED STATES DEPARTMENT OF THE INTERIOR
}

\author{
JAMES G. WATT, Secretary \\ GEOLOGICAL SURVEY \\ Dallas L. Peck, Director
}

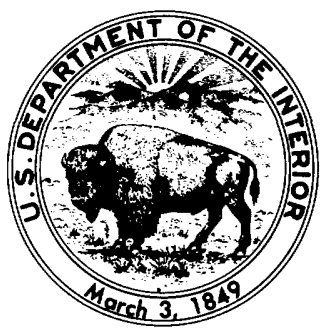

UNITED STATES GOVERNMENT PRINTING OFFICE, WASHINGTON: 1982

For sale by the Branch of Distribution

U.S. Geological Survey

604 South Pickett Street

Alexandria, VA 22304

Library of Congress Cataloging in Publication Data

Barraclough, Jack T.

Hydrologic Conditions at the Idaho National Engineering Laboratory, Idaho-Emphasis: 1974-1978.

(Water Supply Paper 2191)

"Prepared in cooperation with the U.S. Department of Energy."

Bibliography: $52 \mathrm{p}$.

1. Water quality-Idaho-Idaho National Engineer-

ing Laboratory region. 2. Water, underground-Pollu-

tion-Idaho-Idaho National Engineering Laboratory region.

I. Lewis, Barney D. II. Jensen, Rodger G. III.

Title. IV. Series: Geological Survey Water-Supply Paper

2191.

$\begin{array}{llll}\text { TD224.12B37 } 53.7^{\prime} 9^{\prime} 0979659 & 81-6821 & \text { AACR2 }\end{array}$ 


\section{CONTENTS}

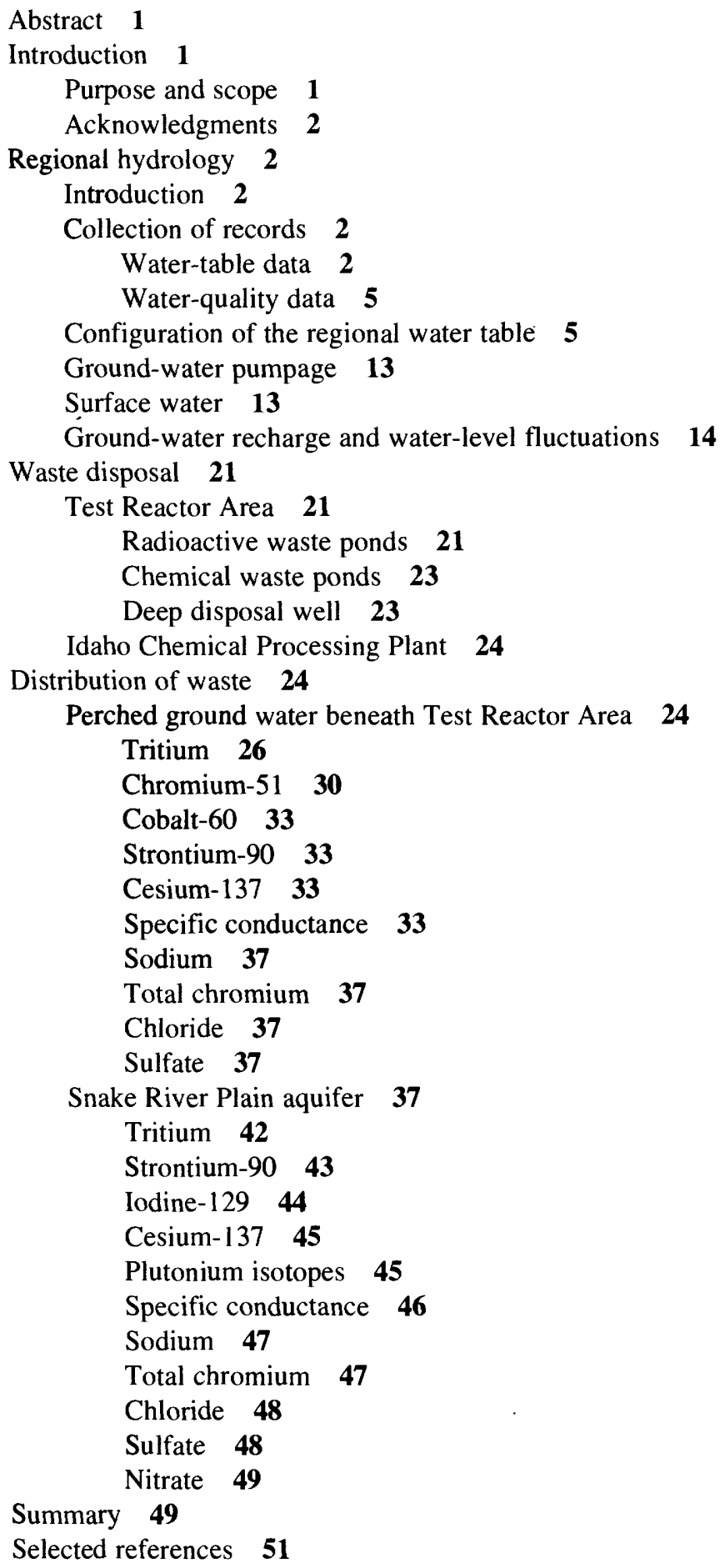




\section{FIGURES}

1. Relief map of Idaho showing the location of the INEL, Snake River Plain, and generalized ground-water flow lines of the Snake River Plain aquifer 2

2. Location of the INEL facilities 4

3. Locations of wells and the frequency of water-level measurements at the INEL and vicinity 6

4. Locations of wells and the frequency of water-level measurements in the TRA-ICPP area 7

5. Locations and frequency of water-sample collections at the INEL and vicinity $\mathbf{8}$

6. Locations of wells from which water samples are collected and the frequencies of water-sample collection in the TRA-ICPP area 9

7. Generalized altitude contours on the regional water table and inferred directions of ground-water movement, INEL and vicinity, July $1978 \mathbf{1 0}$

8. Approximate depth from land surface to the water table, Snake River Plain aquifer, INEL and vicinity, July $1978 \mathbf{1 1}$

9. Net decline of the regional water table, INEL and vicinity, from July 1972 to July $1978 \quad 12$

10. Pumpage from production wells for the major INEL facilities, 1971-1978 14

11. Discharge of the Big Lost River below the Mackay Reservoir 15

12. Average daily discharge of the Big Lost River on the INEL during 1974-1976 at the INEL diversion 16

13. Average daily discharge of the Big Lost River on the INEL during 1974-1976 at the Lincoln Boulevard Bridge near the Test Reactor Area 17

14. Correlation between water-level fluctuations in well 78 and discharge of the Big Lost River at the Lincoln Boulevard Bridge near the TRA 17

15. Hydrographs of three wells in the central part of the INEL $\mathbf{1 8}$

16. Hydrographs of five wells near the southwest corner of the INEL 18

17. Hydrographs of four wells in the western part of the INEL 19

18. Hydrographs of four wells near the southern boundary of the INEL 20

19. Hydrographs of four wells in the eastern part of the INEL $\mathbf{2 0}$

20. Hydrographs of three wells in the northern part of the INEL 21

21. Location of disposal ponds and well, observation wells, and the extent of and water-level contours on the perched ground water in alluvium at the TRA, July $1978 \quad 22$

22. Waste discharged to the radioactive waste ponds and to a deep well at the TRA, and the hydrograph of well 56, which taps the perched ground water in the basalt 23

23. Water-level contours on the surface of the perched ground water in the basalt at the TRA, May 197825

24. Hydrographs of wells MTR test, 54, and 6027

25. Hydrographs of wells 62 and 71 , which tap perched ground water in the basalt at the TRA 27

26. Location of observation wells, production wells, waste disposal ponds, and the disposal well at the TRA $\mathbf{2 8}$

27. Quantity of tritium discharged to the TRA ponds, and tritium concentrations of water from wells $74,73,68$, and 69 , which tap perched ground water in the basalt 29

28. Tritium concentrations of water from TRA ponds, and from wells 56 and 54, which tap perched ground water in the basalt 


\section{FIGURES}

29. Tritium concentrations in water from wells $70,60,61$, and 62 , which tap perched ground water in the basalt at the TRA 30

30. Concentration of tritium in the perched ground water in the basalt at the TRA, April 197831

31. Concentration of chromium-51 in the perched ground water in the basalt at the TRA, April $1977 \quad 32$

32. Concentration of cobalt-60 in the perched ground water in the basalt at the TRA, April $1977 \quad 34$

33. Concentration of strontium-90 in the perched ground water in the basalt at the TRA, April 197535

34. Specific conductance of samples from the perched ground water in the basalt at the TRA, April $1978 \quad 36$

35. Concentration of sodium in the perched ground water in the basalt at the TRA, April 197738

36. Total concentration of chromium in the perched ground water in the basalt at the TRA, April $1975 \quad 39$

37. Concentration of chloride in the perched ground water in the basalt at the TRA, April $1977 \quad 40$

38. Concentration of sulfate in the perched ground water in the basalt at the TRA, October $1975 \quad 41$

39. Location of observation wells completed in the Snake River Plain aquifer, waste disposal wells, and radioactive waste disposal ponds in the ICPP-TRA vicinity $\mathbf{4 2}$

40. Distribution of tritium in the Snake River Plain aquifer, ICPP-TRA vicinity, October $1978 \quad \mathbf{4 3}$

41. Distribution of strontium-90 in the Snake River Plain aquifer, ICPP-TRA vicinity, April 197844

42. Distribution of iodine-129 in the Snake River Plain aquifer, ICPP-TRA vicinity, April $1977 \quad 45$

43. Specific conductance of samples from the Snake River Plain aquifer, ICPP-TRA vicinity, October $1978 \quad 46$

44. Distribution of waste sodium in the Snake River Plain aquifer, ICPP-TRA vicinity, September $1977 \quad \mathbf{4 7}$

45. Distribution of waste chloride in the Snake River Plain aquifer, ICPP-TRA vicinity, September $1977 \quad 48$

46. Distribution of waste nitrate in the Snake River Plain aquifer, ICPP-TRA vicinity January 1979

\section{TABLES}

1. Numbers and types of radiometric or chemical analyses of ground-water samples, 1974-1978 5

2. Discharge of the Big Lost River below Mackay Reservoir, Idaho 14

3. Selected radionuclides discharged to the radioactive waste ponds at the TRA $\mathbf{2 4}$

4. Waste plumes in the Snake River Plain aquifer in the ICPP-TRA vicinity $\mathbf{4 2}$ 
Factors for converting inch-pound units to metric (SI) units

The following factors can be used to convert inch-pound units published herein to the International System (SI) of metric units.

\begin{tabular}{lcl}
\hline Multiply inch-pound units & \multicolumn{1}{c}{$B y$} & To obtain metric units \\
\hline inches (in) & 2.54 & centimeters $(\mathrm{cm})$ \\
feet $(\mathrm{ft})$ & 0.3048 & meters $(\mathrm{m})$ \\
miles $(\mathrm{mi})$ & 1.609 & kilometers $(\mathrm{km})$ \\
square feet $\left(\mathrm{ft}^{2}\right)$ & 0.0929 & square meters $\left(\mathrm{m}^{2}\right)$ \\
acres & 0.4047 & hectares $($ ha) \\
square miles (mi $\left.{ }^{2}\right)$ & 2.590 & square kilometers $\left(\mathrm{km}^{2}\right)$ \\
gallons (gal) & 3.785 & liters $(\mathrm{L})$ \\
gallons (gal) & $3.785 \times 10^{-3}$ & cubic meters $\left(\mathrm{m}^{3}\right)$ \\
million gallons $\left(10^{6}\right.$ gal) & 3,785 & cubic meters $\left(\mathrm{m}^{3}\right)$ \\
acre-feet (acre-ft) & 1,233 & cubic meters $\left(\mathrm{m}^{3}\right)$ \\
pounds $(\mathrm{lb})$ & 0.4536 & kilograms $(\mathrm{kg})$ \\
feet per mile (ft/mi) & 0.1894 & meters per kilometer $(\mathrm{m} / \mathrm{km})$ \\
curies (Ci) & $3.70 \times 10^{10}$ & becquerel $(\mathrm{Bq})$ \\
micromhos $(\mu \mathrm{mho})$ & 1.00 & microsiemens $(\mu \mathrm{S})$ \\
temperature, degrees Celsius & $\left({ }^{\circ} \mathrm{C}\right)=0.556\left({ }^{\circ} \mathrm{F}\right.$ & $32)$
\end{tabular}




\title{
Hydrologic Conditions at the Idaho National Engineering Laboratory, Idaho-Emphasis: 1974-1978
}

\author{
By Jack T. Barraclough, Barney D. Lewis, and Rodger G. Jensen
}

\section{ABSTRACT}

The Idaho National Engineering Laboratory (INEL) site covers about 890 square miles of the eastern Snake River Plain and overlies the Snake River Plain aquifer. Low concentrations of aqueous chemical and radioactive wastes have been discharged to shallow ponds and to shallow or deep wells on the site since 1952 . The regional water table ranges from about 200 feet to more than 1,000 feet below land surface within the INEL boundaries. The gradient of the water table averages about 4 feet per mile to the south-southwest. During the latest period of record, 1974 through 1978, the position of the water table has shown a net decline that ranges from 0.2 foot near the northern boundary of the INEL to more than 10 feet in the central and southern parts of the site. Recharge from surface water has been minimal or non-existent during the latter part of this period.

A large body of perched ground water has formed in the basalt underlying the waste disposal ponds in the Test Reactor Area. This perched zone contains tritium, chromium-51, colbalt-60, strontium-90, and several nonradioactive ions. Tritium is the only mappable waste constituent in that portion of the Snake River Plain aquifer directly underlying this perched zone.

Low concentrations of chemical and low-level radioactive wastes enter directly into the Snake River Plain aquifer through the Idaho Chemical Processing Plant (ICPP) disposal well. From 1974 through 1978, this 600 -foot well was used to discharge a total of 1,861 million gallons of waste water which contained 1,697 curies of radioactivity, 95 percent of which was tritium. Tritium has been discharged to the well since 1953 and has formed the largest waste plume, about 28 square miles in area, in the regional aquifer, and minute concentrations have migrated downgradient a horizontal distance of 7.5 miles. Other waste plumes south of the ICPP contain sodium, chloride, nitrate, and the resultant specific conductance. These plumes have similar configurations and flow southward; the contaminants are in general laterally dispersed in that portion of the aquifer underlying the INEL.

Other waste plumes, containing strontium-90 and iodine-129, cover small areas near their points of discharge because strontium-90 is sorbed from solution as it moves through the aquifer and iodine-129 is discharged in very low quantities. Cesium-137 is also discharged through the well but it is strongly sorbed from solution and has never been detected in a sample of ground water at the INEL. Radionuclide plume size and concentrations therein are controlled by aquifer flow conditions, the quantity discharged, radioactive decay, sorption, dilution by dispersion, and perhaps other chemical reactions. Distributions of nonradioactive chemical wastes are subject to the same processes except for radioactive decay.

\section{INTRODUCTION}

The Idaho National Engineering Laboratory (INEL), formerly the National Reactor Testing Station (NRTS), was established in 1949 by the United States A.tomic Energy Commission (AEC) (later reorganized as Energy Research and Development Administration (ERDA.), and now as the Department of Energy (DOE)) to build, operate, and test various types of nuclear reactors. The reactors are built primarily to develop peacetime uses of atomic energy. Fifty-two reactors have been constructed to date, of which 17 are still operable.

The INEL site covers about 890 square miles on the eastern Snake River Plain (fig. 1) and has an average altitude of 4,900 feet above sea level. This plain is underlain by the Snake River Plain aquifer, the major aquifer in Idaho. The INEL obtains its entire water supply from this aquifer. Aqueous chemical and radioactive wastes are discharged to shallow ponds and to shallow or deep wells. The pond and shallow-well wastes infiltrate the ground, form perched bodies of water, and then percolate toward the Snake River Plain aquifer.

The study of the hydrology of subsurface waste disposal requires a knowledge of the hydrogeology of the Snake River Plain aquifer, the locations and quantities of waste disposed, the methods of disposal, and the geochemistry of the waste solutions and of the water in the aquifer. During recent years, the prime concern has been to trace the movement of low-level radioactive wastes in the subsurface and to explain the chemical and radiochemical changes that accompany such movement in terms of the geologic, hydrologic, and geochemical factors that influence these changes.

\section{PURPOSE AND SCOPE}

In 1949, the AEC requested the U.S. Geological Survey to investigate and describe the water resources of the INEL and adjacent areas. Information was collected which depicted hydrogeologic conditions prior to any reactor op- 


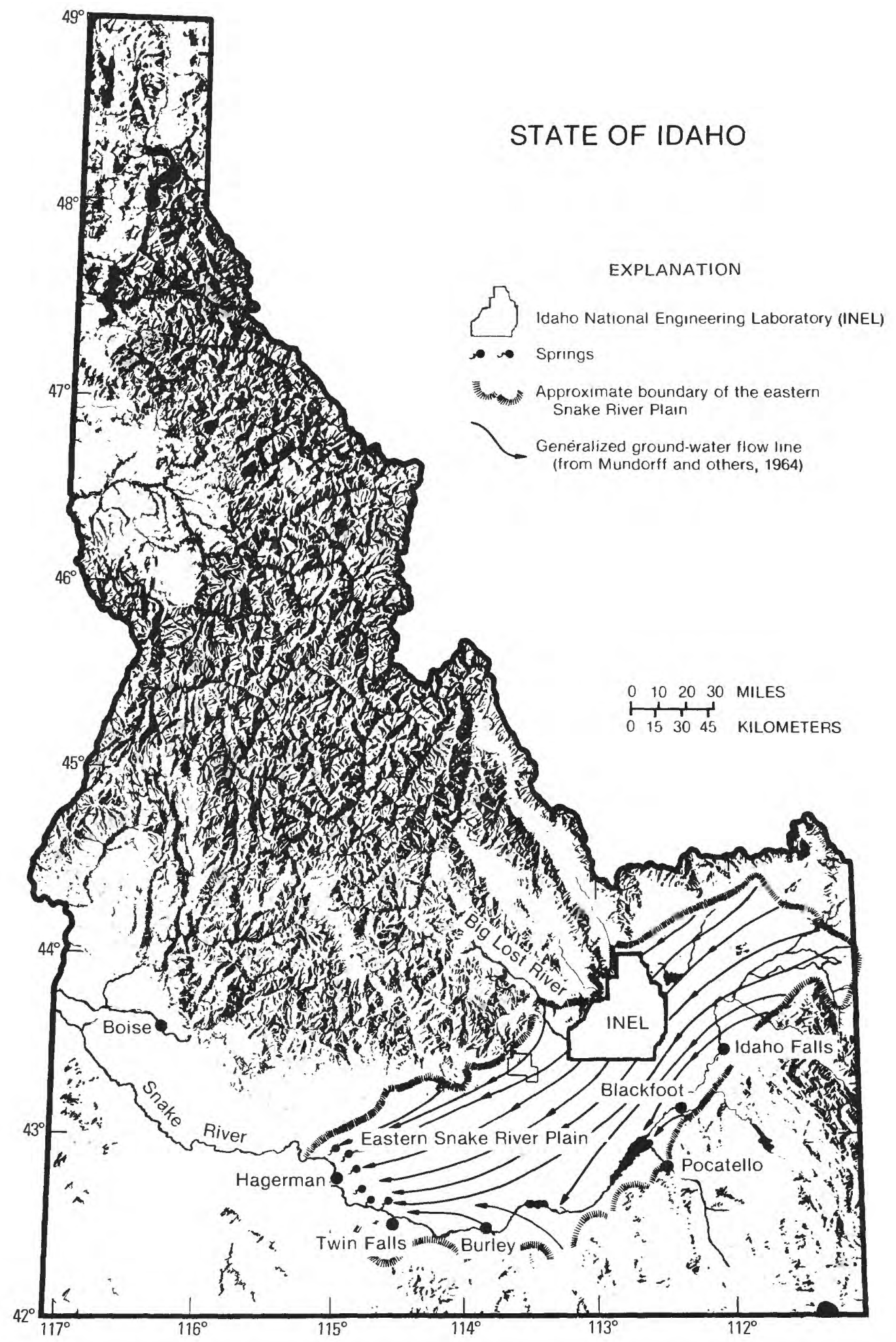

Figure 1. Relief map of Idaho showing the location of the INEL, Snake River Plain, and generalized ground-water flow lines of the Snake River Plain aquifer. 
erations at the Laboratory. Current investigations serve to determine natural changes in the hydrogeology and also to determine changes resulting from activities at the Laboratory.

This report covers the water-level and water-quality data collected by the U.S. Geological Survey during the calendar years 1974 through 1978, and the resulting hydrologic interpretations. The report therefore covers a period following that covered by a previous report by Barraclough and Jensen (1976), which summarized the influences of waste disposal from 1971 to 1973. Reports on previous Geological Survey investigations describing geologic and hydrologic studies of the area and related reports by the DOE staff are listed in the references and may be obtained from the INEL library or from the offices of the Geological Survey at Central Facilities Area (CFA) (fig. 2).

\section{Acknowledgments}

These studies have been sponsored and funded by the Energy Research and Development Administration, now the Department of Energy, through Gerald H. Daly, former chief, Technology Branch, Division of Waste Products, Office of Nuclear Waste Management, and James E. Dieckhoner, Chief, Operations Branch, Division of Waste Products. The U.S. Geological Survey project at the INEL was administered through the Office of Waste Management, George Wehmann, former Director; Dr. C. W. Bills, former Assistant Manager for Energy and Technology; and later through J. P. Hamric, Director, Nuclear Fuel Cycle and Waste Management Division, J. B. Whitsett, Chief, Radioactive Waste Programs Branch; and M. M. Williamson, Director, Radiological and Environmental Sciences Laboratory, Idaho Operations Office (IDO). Considerable assistance has also been obtained from the following DOE-IDO personnel: the staff of the Analytical Chemistry Branch, C. W. Sill, former Chief, and L. Z. Bodnar, Chief, who provided most of the radiometric analyses of ground-water samples; Dr. A. H. Dahl, and Dr. W. L. Polzer, formerly of the Environmental Sciences Branch, and E. W. Chew, Chief; and Dr. D. I. Walker, former Director of the Health Services Laboratory.

\section{REGIONAL HYDROLOGY}

\section{Introduction}

The eastern Snake River Plain is a large graben or downwarped structural basin, $12,000 \mathrm{mi}^{2}$ in area (fig. 1).
It has been filled to its present level with approximately 2,000 to 10,000 feet of thin basaltic lava flows, rhyolite deposits, and interbedded sediments. A more detailed description of the geology is found in Robertson, Schoen, and Barraclough (1974). Nearly all of the eastern Snake River Plain is underlain by a vast ground-water reservoir known as the Snake River Plain aquifer, which may contain more than 1 billion acre-feet of water. The flow of ground water in the aquifer is principally to the south-southwest (fig. 1) at relatively high velocities of 5-20 feet per day (Robertson, Schoen, and Barraclough, 1974, p. 13). The transmissivity of the aquifer is high, generally ranging from 1 million to 100 million gallons per day per foot or 134,000 to $13,400,000$ square feet per day (Robertson, Schoen, and Barraclough, 1974, p. 12).

The basaltic volcanic rocks and interbedded sediments composing the aquifer are all included in the Snake River Group of Quaternary age. The basement rocks are probably composed of older volcanic and sedimentary rocks, in addition to any underlying crystalline rocks. The basalt is the principal aquifer. Water-bearing openings in the basalt are distributed throughout the rock system in the form of intercrystalline and intergranular pore space, fractures, cavities, interstitial voids, interflow zones, and lava tubes. The variety and degree of interconnection of these openings complicates the direction of ground-water movement locally throughout the aquifer.

Ground-water recharge to the INEL is primarily by underflow from the northeastern part of the plain and also from adjacent drainages on the west and north. Most of the ground water underlying the INEL entered the ground in the uplands to the north, northeast, and northwest of the site; it is moving south or southwestward through the aquifer and will discharge at springs along the valley of the Snake River near Hagerman (fig. 1). Lesser amounts of the water are derived from local precipitation on the plain. Part of the precipitation evaporates but part infiltrates the ground surface and percolates through the subsurface to the regional water table.

\section{Collection of Records}

\section{Water-table Data}

The water-table observation well program was designed to determine the changes in gradient that influence the rate and direction of ground water and radionuclide movement, to identify sources of recharge to the aquifer, and to measure the areal extent of the effects of recharge. Water levels were measured in both the regional aquifer and perched aquifers. Seven continuous water-level re- 


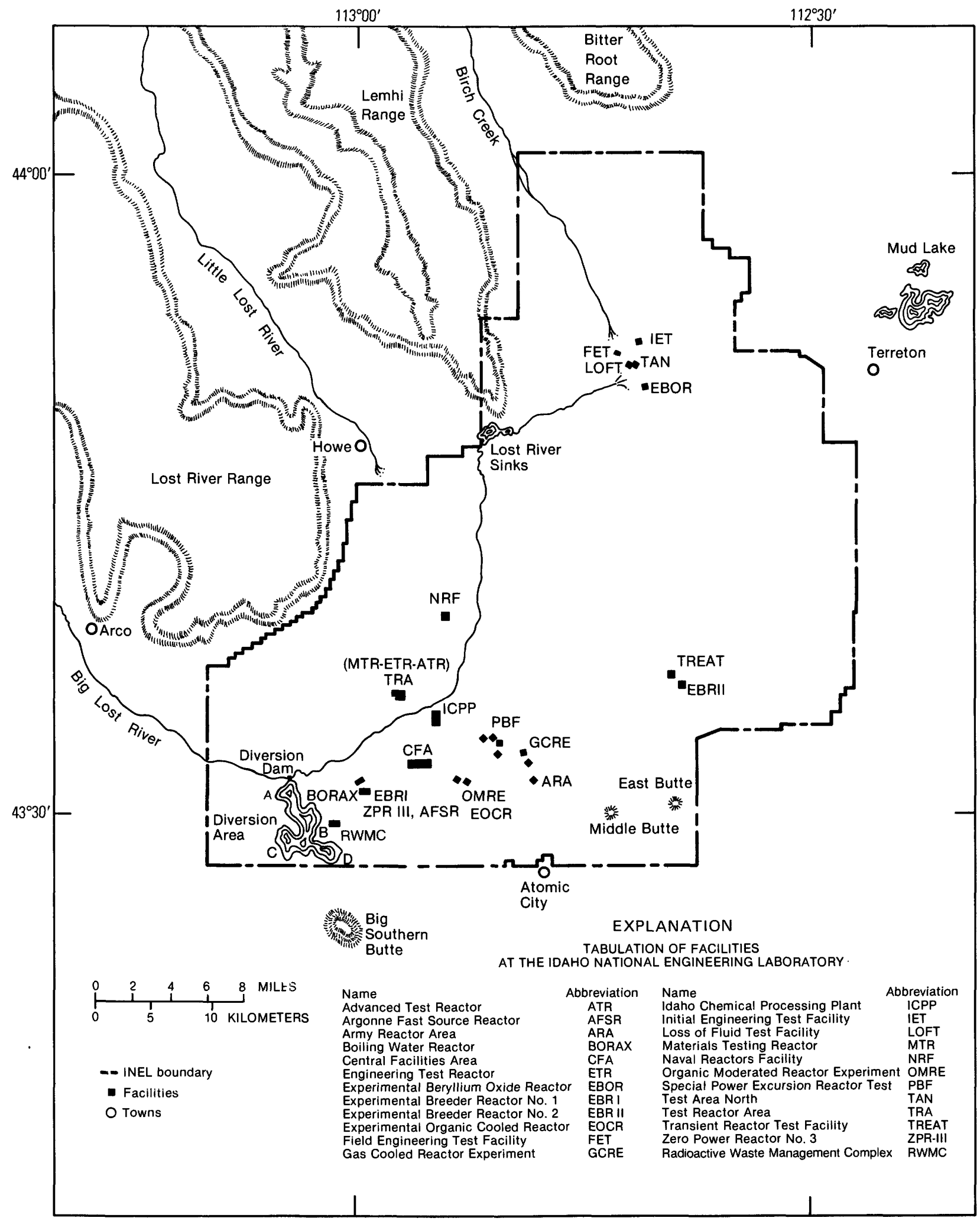

Figure 2. Location of the INEL facilities.

corders were operated from 1974 to 1978; water levels were measured monthly in 53 wells, and annually in 47 , in order to study the regional water table. To study perched water bodies, two wells were equipped with continuous water-level recorders, and water levels in 13 were measured monthly; 9 were measured quarterly; and 91 were 
measured annually. A total of 3,841 water-level measurements were made from 1974 to 1978 , for an average of 768 measurements per year.

Figures 3 and 4 show the locations of water-level observation wells and the frequency of water-level measurements. The measurements are all on file in the office of the U.S. Geological Survey at the INEL.

\section{Water-quality Data}

The study of the chemical and radiometric character of ground water in the INEL area was based on analysis of water samples collected in a comprehensive sampling program. The type, frequency, and depth of sampling generally depended upon the information needed in a specific area. The program included analyses for tritium, strontium- 90 , cobalt- 60 , chromium-51, iodine- 129 , cesium137, plutonium-238, plutonium 239-240, americium-241, total chromium, specific conductance, sulfate, chloride, nitrate, and chemical analysis of 28 of the more common chemical constituents or parameters per water sample.

Water samples have been collected throughout the Laboratory site and in adjacent areas to define the chemical character of the ground water entering and leaving the INEL. Near areas of detailed study, such as the Test Reactor Area (TRA) and the Idaho Chemical Processing Plant (ICPP), numerous samples were taken in order to establish the contamination levels and to follow the migration of wastes in both the perched and the regional ground-water bodies.
The locations and the frequency of wells sampled on or near the INEL are shown in figures 5 and 6 . Water samples for tritium analyses were collected from wells near ICPP and TRA on a quarterly and semi-annual basis. Water samples for the determination of tritium concentrations and specific conductances were obtained from three wells which intercept ground-water underflow near areas of recharge at the north end of the INEL. Nearby surfacewater samples were also collected at about the same time. An average of 1,506 chemical and radiometric analyses were made on 223 water samples collected annually from 1974 through 1978. A total of 182 samples were collected from production wells, 933 from observation wells, and 42 from streams on or near the INEL. From these 1,157 samples, 7,813 analyses were made for chemical or radiometric determinations. Surface-water samples were collected from the following: Big Lost River near Moore, Idaho; Birch Creek near Blue Dome, Idaho; Little Lost River near Howe, Idaho; and Mud Lake near Terreton, Idaho. The total number and types of analyses are given in table 1.

\section{Configuration of the Regional Water Table}

Figure 7 is a map of the INEL site and adjacent areas showing altitude contours on the water table of the Snake River Plain aquifer for July 1978 and the inferred directions of ground-water movement. The altitude of the water table ranges from 4,584 feet above the geodetic vertical datum in the northern part of the site to 4,426 feet near the

Table 1. Numbers and types of radiometric or chemical analyses of ground-water samples, 1974-1978

\begin{tabular}{|c|c|c|c|c|c|}
\hline \multirow[b]{2}{*}{ Analysis } & \multicolumn{5}{|c|}{ Number and Year } \\
\hline & 1974 & 1975 & 1976 & 1977 & 1978 \\
\hline Tritium & 255 & 249 & 186 & 251 & 209 \\
\hline Strontium-90 & 106 & 83 & 92 & 44 & 71 \\
\hline Cobalt- 60 & -- & 17 & - & 15 & -- \\
\hline Carbon-14 & -- & -- & - & -- & 5 \\
\hline Cerium-144 & -- & 17 & -. & -- & - \\
\hline Plutonium-238 & 48 & 66 & 11 & 5 & 9 \\
\hline Plutonium-239, 240 & 48 & 66 & 11 & 5 & 9 \\
\hline Americium-241 & 48 & 66 & 11 & 5 & 9 \\
\hline Gamma Spectrometry & 45 & 45 & 11 & 7 & 8 \\
\hline Sulfate & -- & 85 & - & -- & -- \\
\hline Nitrate & -- & - & - & -- & a36 \\
\hline Standard Chemical & ${ }^{b} 140$ & ${ }^{b} 140$ & - & ${ }^{c} 3,782$ & 5 \\
\hline
\end{tabular}

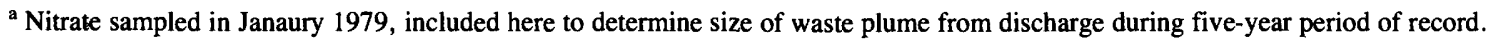

${ }^{b}$ Five water samples were analyzed for 28 determinations each.

c Thirty-one determinations were made on each of 122 samples.
} 


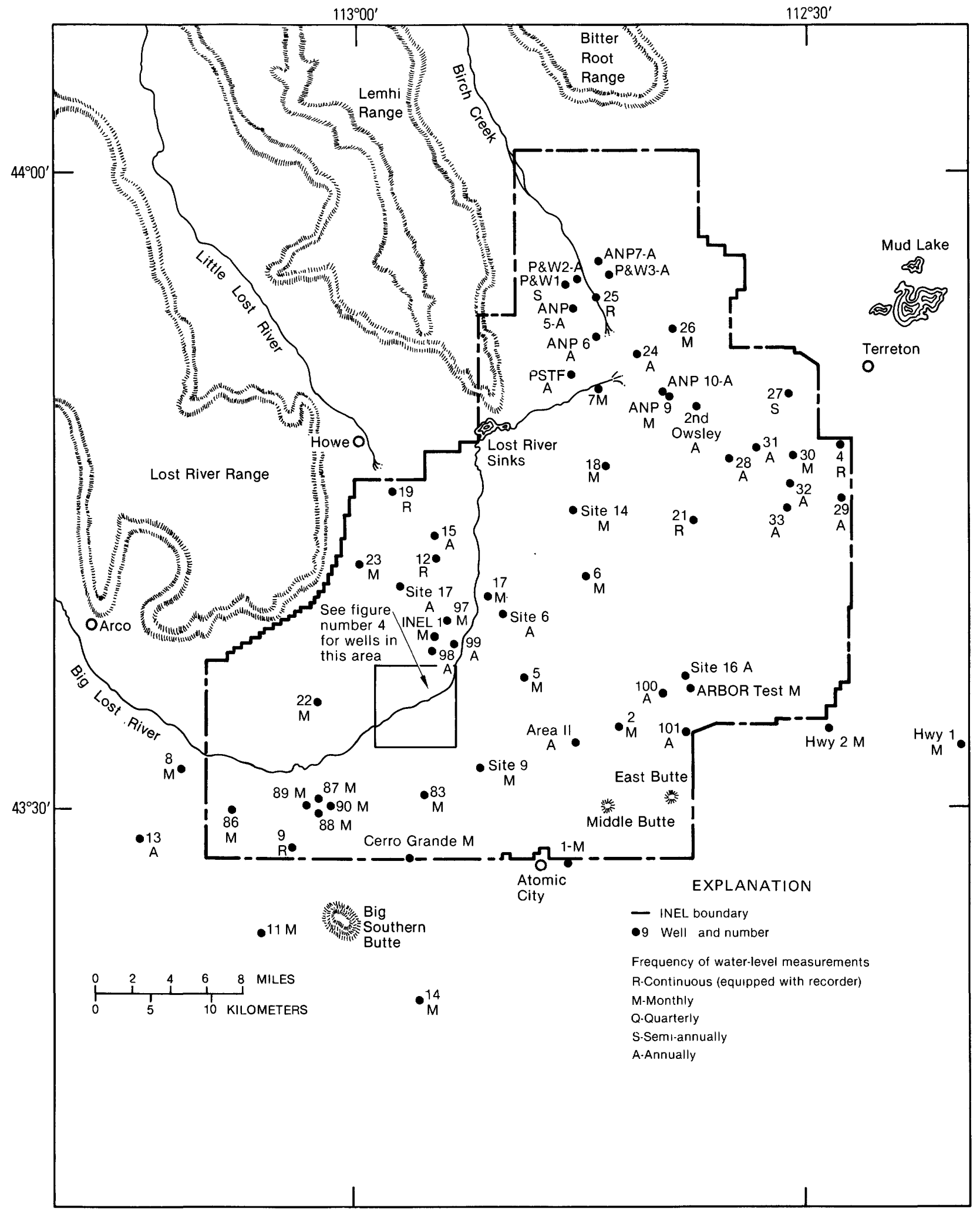

Figure 3. Locations of wells and the frequency of water-level measurements at the INEL and vicinity. 


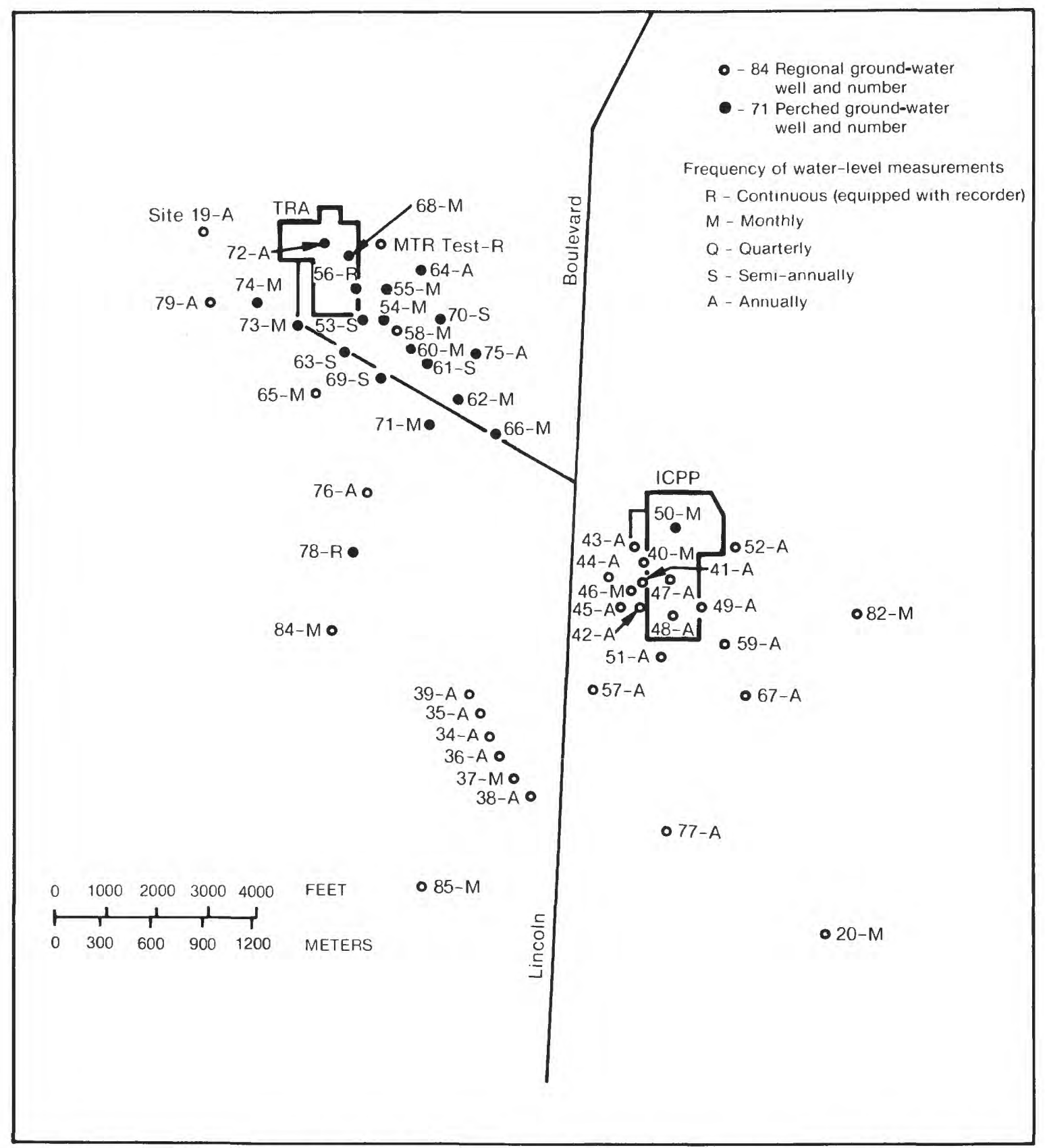

Figure 4. Locations of wells and the frequency of water-level measurements in the TRA-ICPP area.

southwestern boundary of the site. The general direction of regional ground-water movement underlying the INEL is to the south and southwest. The average slope of the water table is about 4 feet per mile. In the northern part of the INEL, near the Birch Creek valley, the water-table gradient is relatively low, sloping southward about 1 foot per mile (fig. 7).
Figure 8 is a map showing the approximate depth from the land surface to the water table in the Snake River Plain aquifer at the INEL. The depth to water ranges from about 200 feet to more than 1,000 feet. The configuration shown on figure 8 generally reflects the surface topography. The actual depth to the regional water table varies with the recharge received by the system over some period 


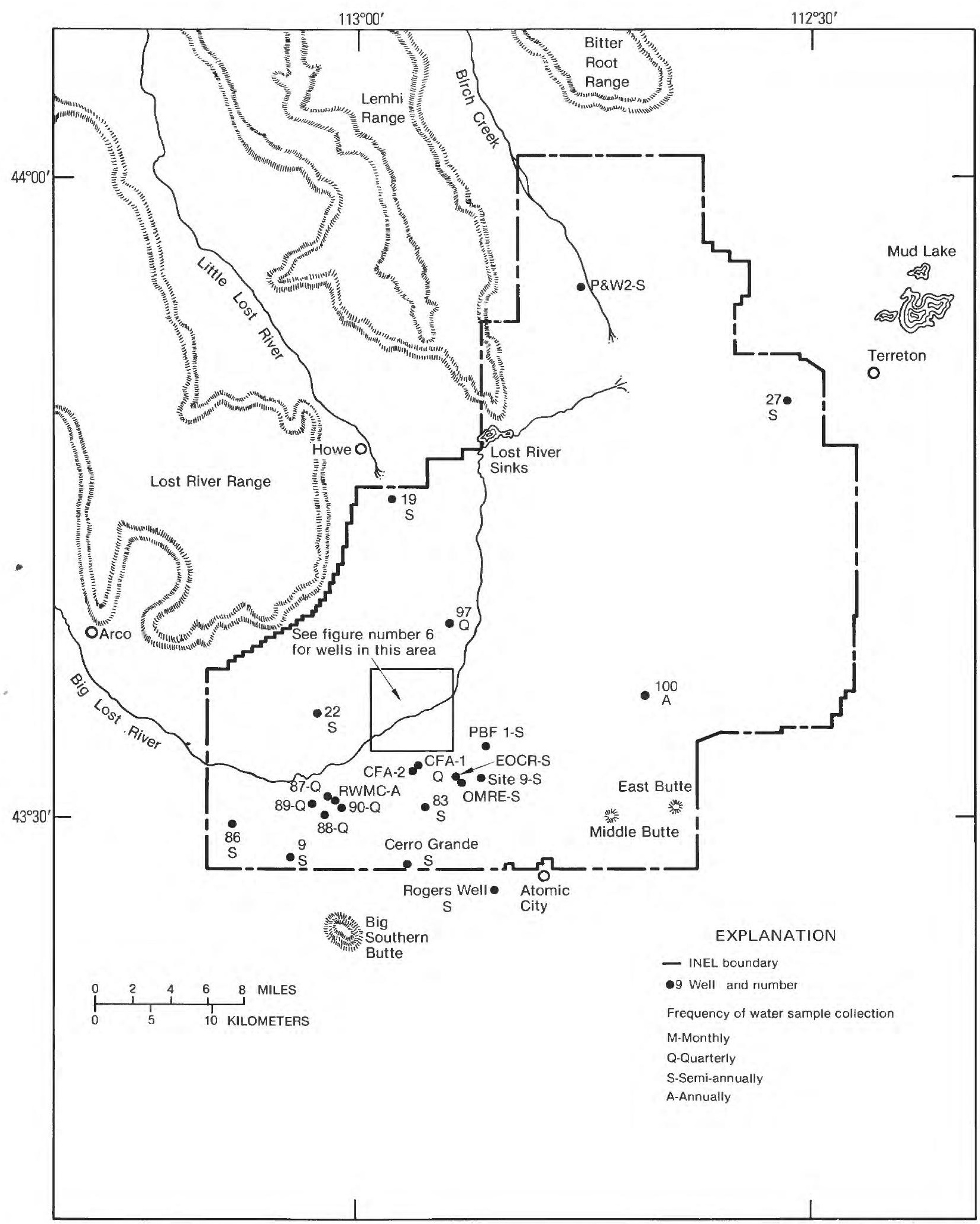

Figure 5. Locations and frequency of water-sample collections at the INEL and vicinity. 


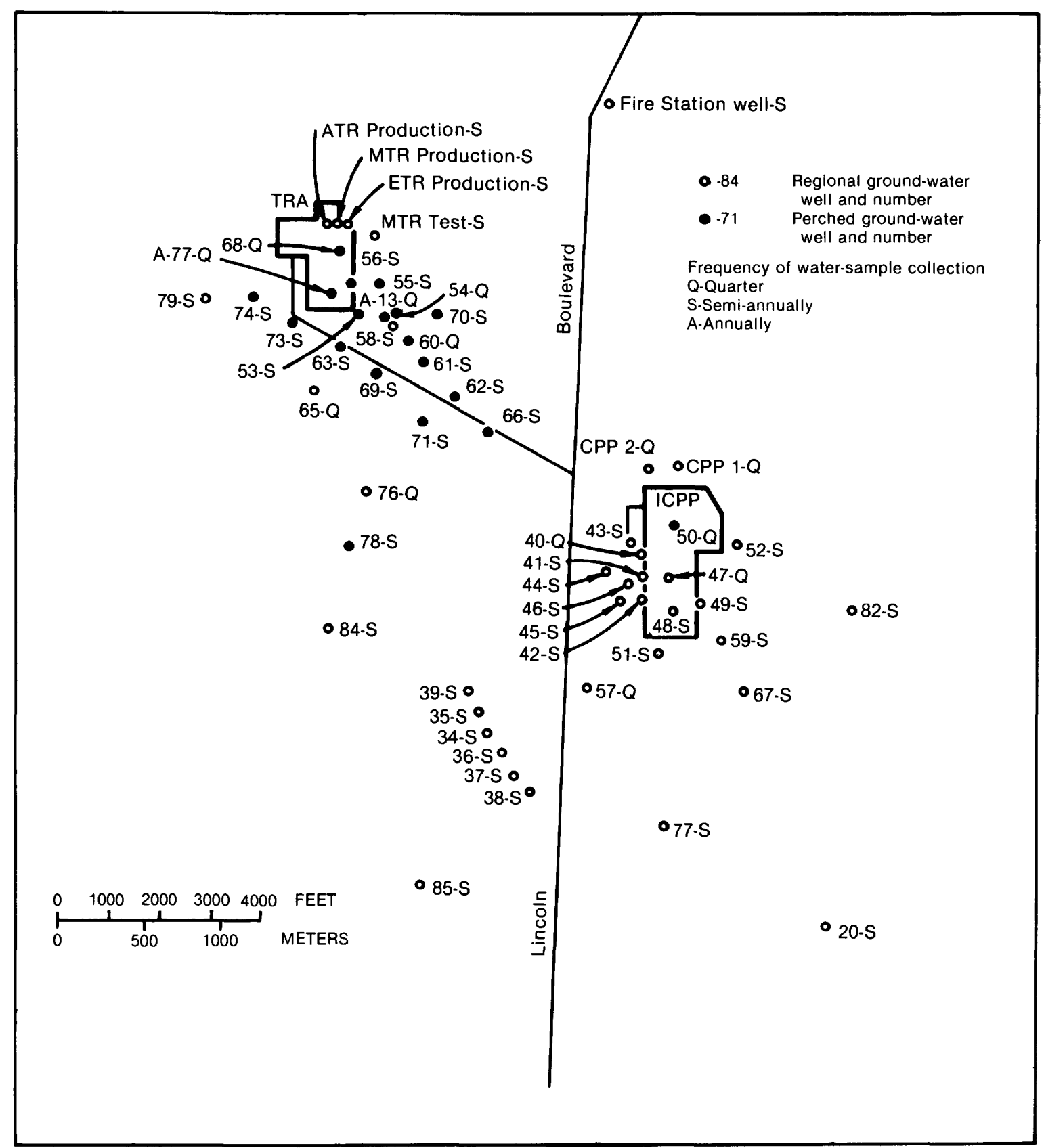

Figure 6. Locations of wells from which water samples are collected and the frequencies of water-sample collection in the TRA-ICPP area.

prior to the measurement of water levels. From 1974 through 1978, recharge has been considerably less than discharge and collected data show that the relative vertical position of the water table has fallen. Figure 9 shows this decline from July 1972 to July 1978. Near the northern boundary of the INEL, where recharge from the Birch
Creek and Mud Lake area has been maintained by longterm consistency, the decline has been as little as 0.2 foot. In the central and southern parts of the INEL, declines have been greater than 10 feet in four observation wells that are sensitive to changes in recharge from the Big Lost River, which has been abnormally low for the past three 


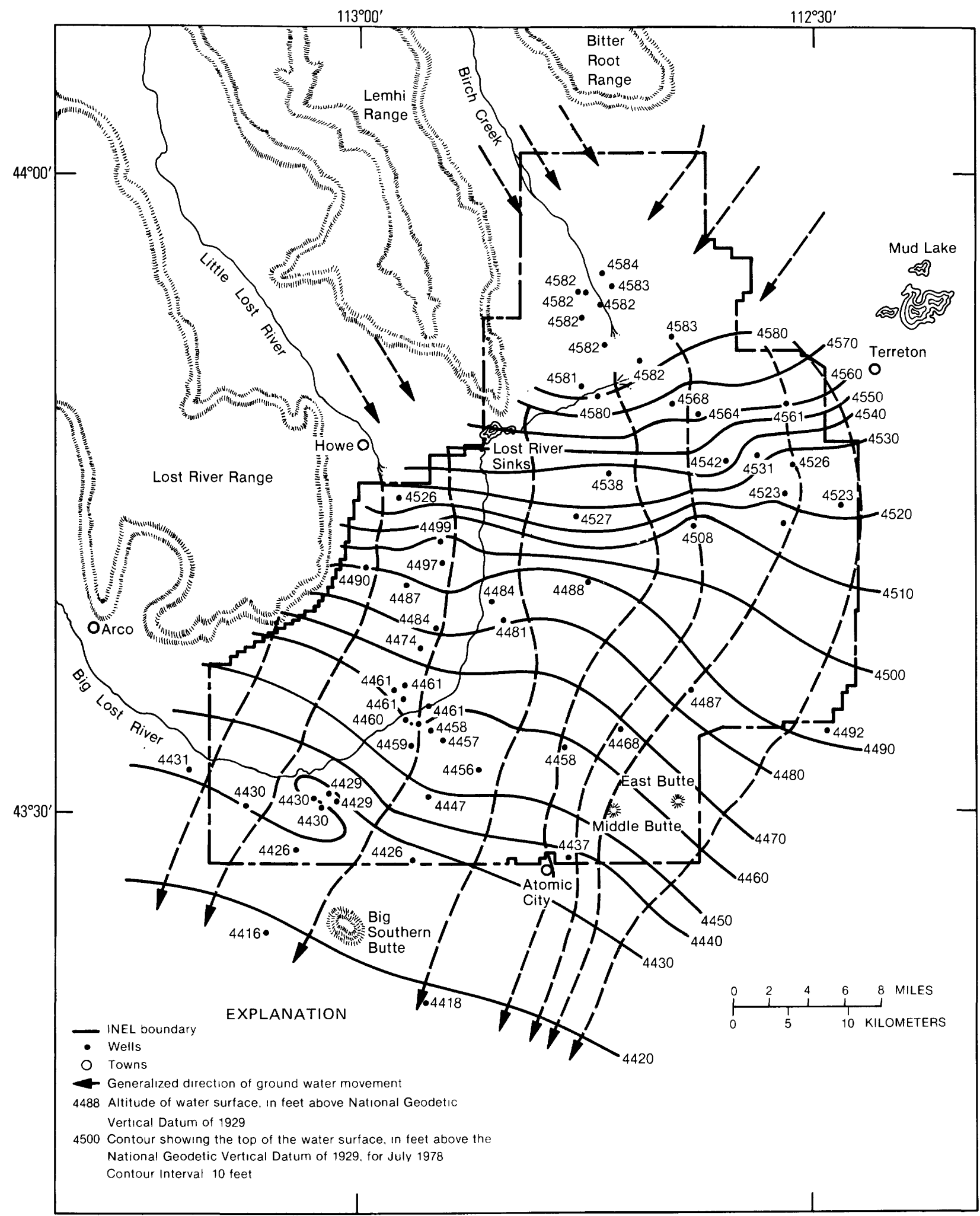

Figure 7. Generalized altitude contours on the regional water table and inferred directions of ground-water movement, INEL and vicinity, July 1978. 


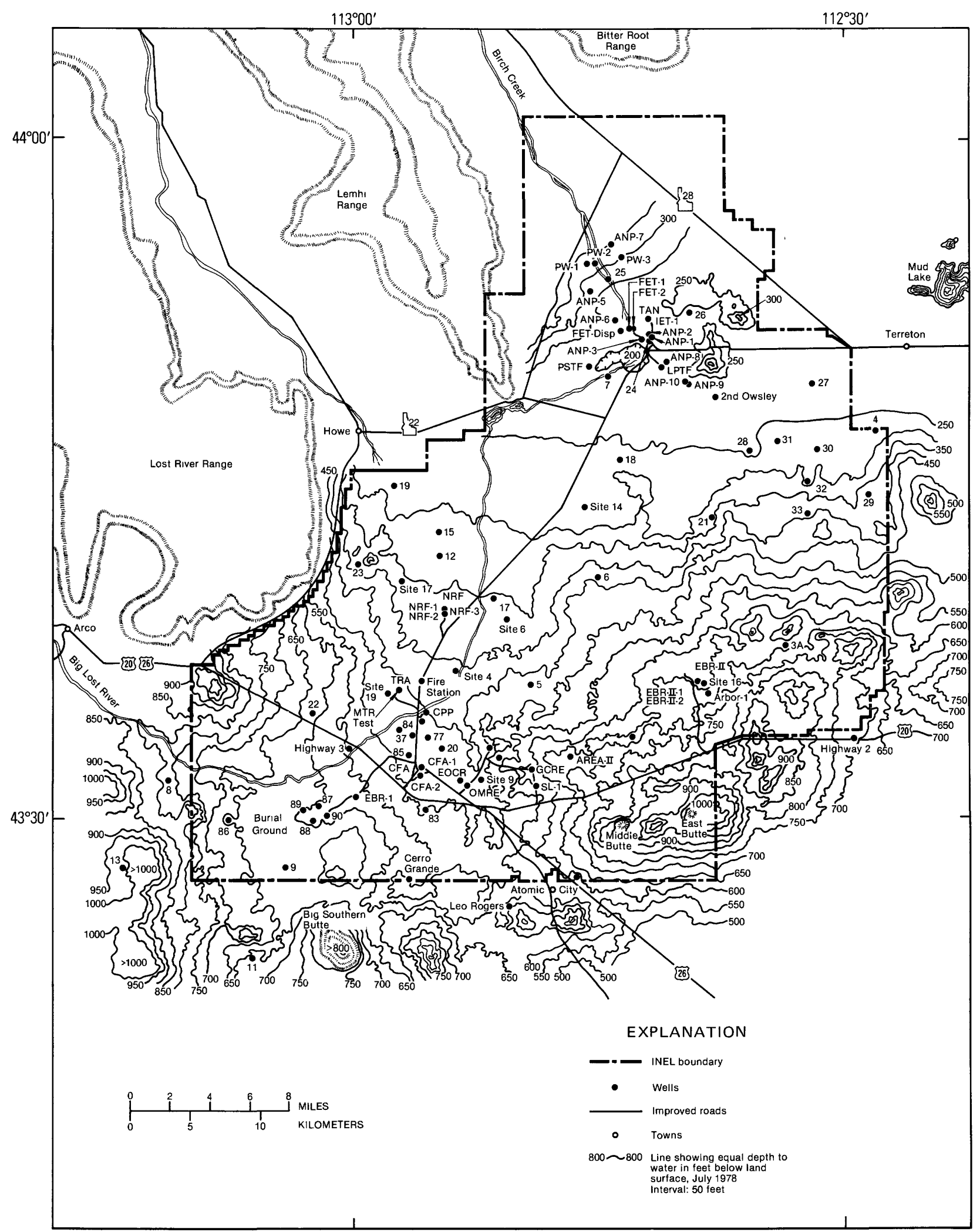

Figure 8. Approximate depth from land surface to the water table, Snake River Plain aquifer, INEL and vicinity, July 1978. 


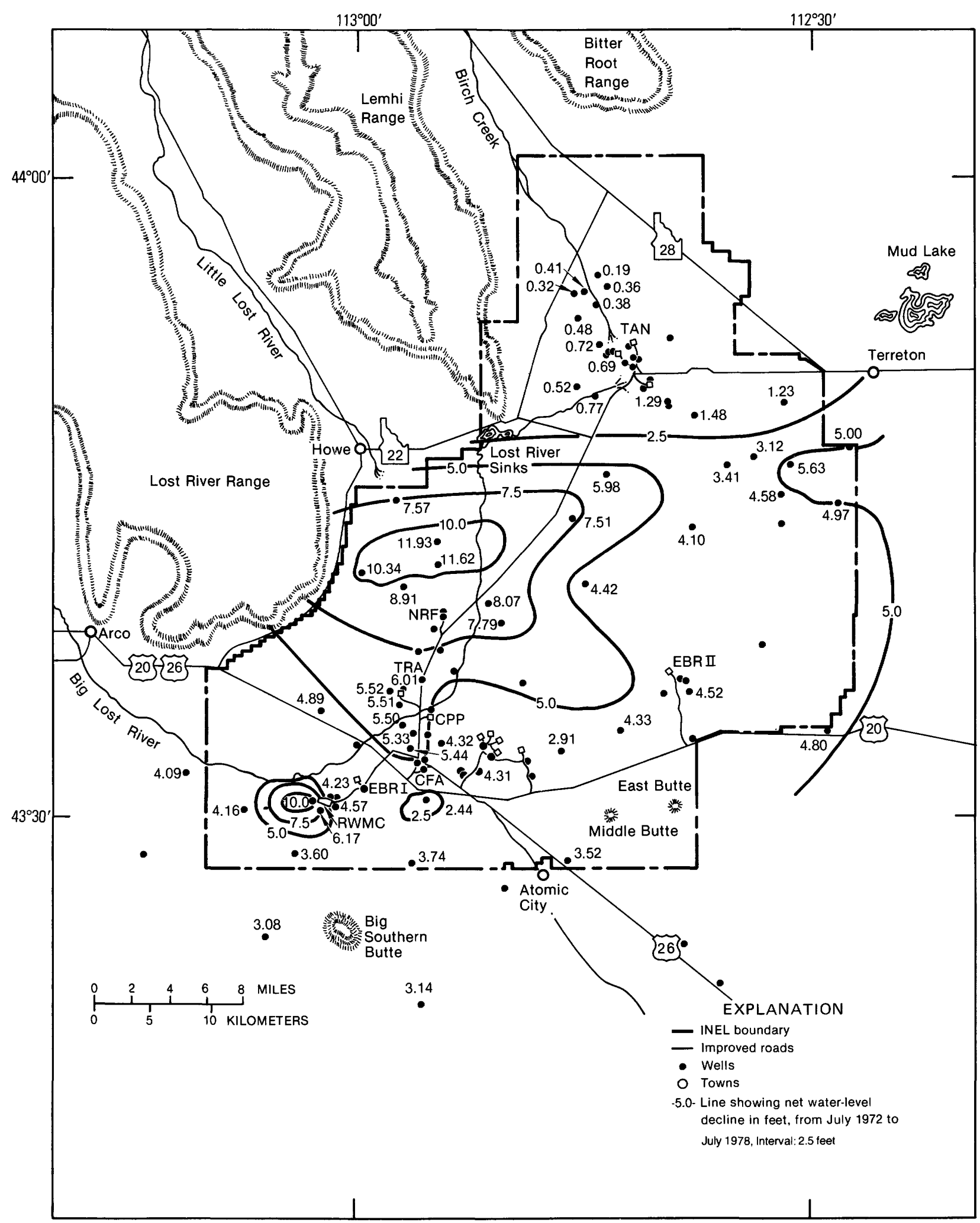

Figure 9. Net decline of the regional water table, INEL and vicinity, from July 1972 to July 1978. 
years. In addition, pumping from production wells at a few facilities has increased over the same period and may have contributed slightly to the declines.

\section{Ground-Water Pumpage}

The Snake River Plain aquifer is the only source of water utilized at the INEL. Twenty-five of the 28 production wells on the INEL were generally used from 1974 1978. The combined pumpage of these wells was about 2.5 billion gallons of water per year for 1974-78. This averages about 6.9 million gallons per day or 7,780 acre-feet per year.

Figure 10 illustrates the pumpage of water by the major facilities at the INEL from 1971 through 1978. More water was pumped in 1974 than in any other year. The TRA (fig. 2) is the largest user of ground water at the INEL. The quantity of water used at TRA has generally decreased over latest period of record. The quantity of water used at the ICPP has generally increased over this time period. The quantity of water used at the Naval Reactor Facility (NRF) increased from 1971 to its greatest volume in 1974, decreased in 1975 and 1976, and then increased again over the next two years. The quantity of water used at all the other facilities is a rather small percentage of the total (about 15 percent).

Not all the water pumped out of the aquifer is actually consumed. Some of the waste water is discharged directly back into the Snake River Plain aquifer through deep disposal wells. Other aqueous wastes (radioactive, chemical, and sewage) are discharged into ponds or shallow wells. Both methods of waste disposal contribute recharge to the aquifer. AEC, ERDA, and DOE annual reports (compiled by S. S. White) give the volumes of wastes disposed to the air, surface, subsurface, and sewage. From 1974 through 1978, about 60 percent of the water pumped was disposed to the surface or subsurface. Pumpage has a limited effect on annual water-level changes in the aquifer in the vicinity of the INEL because the amount pumped is a very small portion of the total storage and recharge.

\section{Surface Water}

The surface water is mainly that in streams draining the mountains and valleys to the west and north of the INEL (see fig. 1). Localized snowmelt and rain also contribute to surface water, especially in the spring. Water from the Big Lost River and Birch Creek enters the INEL during wet years. Most of the flow of the Little Lost River and Birch Creek is diverted for irrigation before it reaches the INEL.

The Big Lost River is the INELS's most important source of surface water. Recharge to the Snake River Plain aquifer from flow during wet years has been significant. All of the flow that enters onto the Snake River Plain is recharged to the subsurface, except for evaporation and transpiration losses. During dry periods, flow does not reach the INEL.

The Big Lost River flows southeastward down the Big Lost River Valley past Arco, onto the Snake River Plain, and then turns northward through the INEL to its termination in playas (or Lost River Sinks-see fig. 2). The river loses water by infiltration through the channel bottom as it flows on the plain. As flow approaches the terminal playas, the channel branches into many distributaries and the flow spreads over several flooding and ponding areas (Barraclough and others, 1967, p. 21).

Two additional major artificial controls affect the river, in addition to the irrigation diversions. These are the Mackay Dam, 30 miles upstream from Arco, and the INEL flood-diversion system in the southwestern part of the INEL site (fig. 2). The INEL flood-control diversion system was constructed in 1958 to reduce the threat of floods from the Big Lost River on that part of the site. The diversion dam can divert flow out of the main channel to spreading areas A, B, C, and D. (See Lamke, 1969, for discussion of flood control.) During winter months nearly all flow is diverted to avoid accumulation of ice in the main channel and preclude the possibility of flooding INEL facilities.

During water year 1974, the flow of the Big Lost River below Mackay Reservoir was 319,900 acre-feet, the fourth highest discharge of record (fig. 11 and table 2). The flow during water year 1975 was 317,100 acrefeet, the fifth highest discharge of record. The period of highest average flow for the entire historical record was from 1965 through 1976, with 1965, 1969, 1967, 1974, 1975, and 1971 recording the six highest flows of record in order of decreasing magnitude. Following the very high years of 1974 to 1976 , the total discharge decreased during the next year (1977) to a discharge much lower than normal, 160,300 acre-feet. During the 1978 water year the discharge was measured at 225,900 acre-feet, slightly above average.

The flow of the Big Lost River at the INEL diversion for 1974 through 1976 is shown on figure 12. Continuous flow was recorded for all three years. In 1974, the flow was rather uniform except for a peak flow of more than 1,200 cubic feet per second (cfs) in late June. During that year, a total of 70,000 acre-feet flowed down 


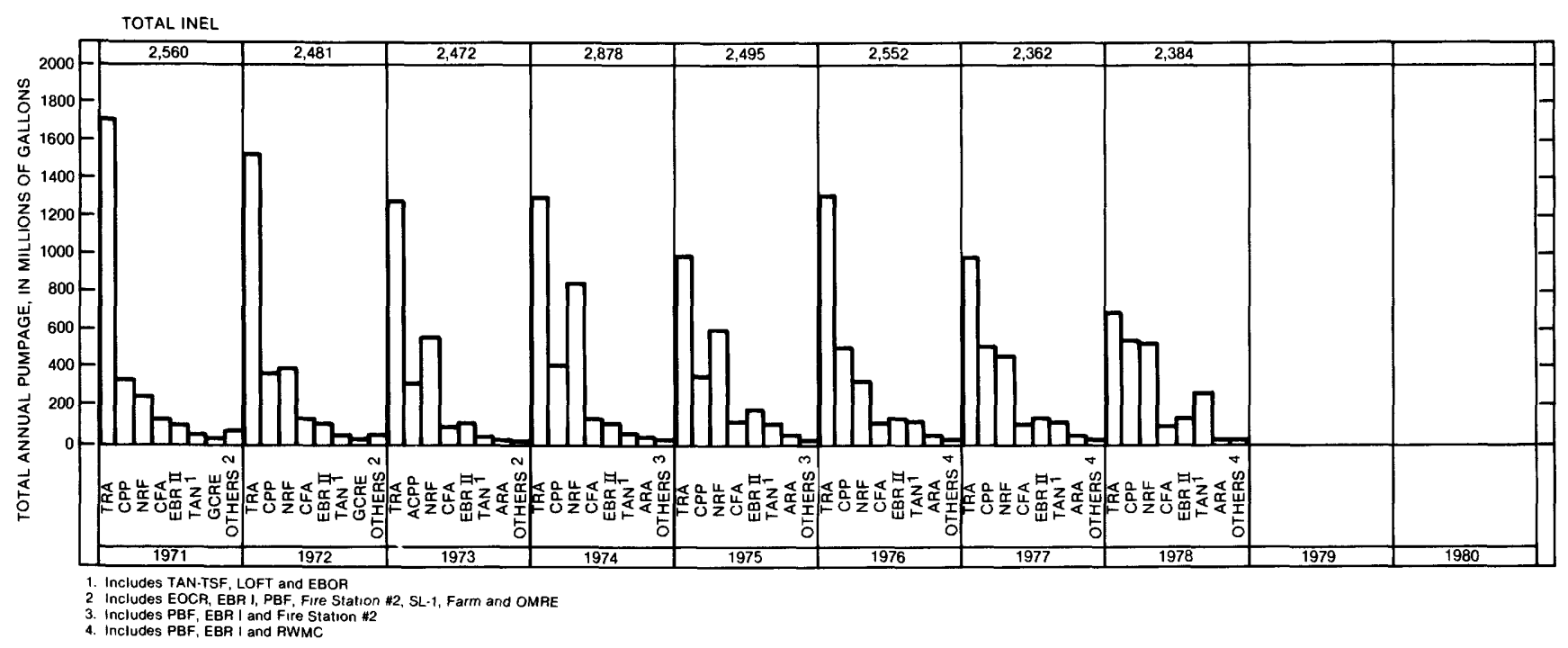

Figure 10. Pumpage from production wells for the major INEL facilities, 1971 to 1978.

Table 2. Discharge of the Big Lost River below Mackay Reservoir, Idaho
Water Year

\section{4}

1975

1976

1977

1978

1965 (maximum)

62-year average
Discharge (acre-ft)

319,900

317,100

263,600

160,300

225,900

397,000

214,700 the main channel and 32,000 acre-feet flowed into the INEL diversion.

Figure 12 shows that during 1975, four peak flows conspicuously greater than the remainder of the record were recorded at the diversion. In May and June, the total flow was more than $500 \mathrm{cfs}$ and in July the peak flow exceeded 1,000 cfs. In November, the peak flow reached almost $500 \mathrm{cfs}$ for a brief period. A total of 88,000 acre-feet flowed down the main channel and 46,000 acre-feet flowed into the INEL diversion during 1975.

In 1976 two small flow peaks were registered on the discharge curve for the Big Lost River at the INEL diversion (fig. 12). One peak in mid-May had a total flow of $240 \mathrm{cfs}$, and the other in mid-November had a total flow of $280 \mathrm{cfs}$. During this relatively dry year a total of 38,000 acre-feet of water flowed through the diversion channel while 18,000 acre-feet flowed through the main channel. Two very dry years followed 1976 and flow in either channel of the Big Lost River was generally below the detection limits of the gaging stations (approximately 5 cfs). The only flow peak occurring during 1977 or 1978 was in March of 1977. The duration of this peak was however very short lived, lasting only two or three days, and attained a maximum flow of about $50 \mathrm{cfs}$. Prior to this peak, the average flow for the preceding two months was about $20 \mathrm{cfs}$. Therefore, flow curves plotted for the river at the INEL diversion for these last two years of record would have little meaning and are omitted.

Figure 13 shows the flow of the Big Lost River at the Lincoln Boulevard Bridge near the TRA during 1974, 1975, and 1976. Because of operation of the control gates at the INEL diversion, downstream flow measured at the bridge usually begins in March or April and terminates in November. The flow at the Lincoln Boulevard Bridge was 52,000 acre-feet during 1974, 72,000 acrefeet during 1975, and 6,700 acre-feet during 1976. During 1977 or 1978 no flow was recorded at this gaging station, illustrating the unusually dry period that began in 1976.

\section{Ground-Water Recharge and Water-Level Fluctuations}

As previously stated, the Big Lost River flows occasionally onto the INEL. Water infiltrates from the river during periods of flow and percolates toward the Snake River Plain aquifer. Lowly permeable sedimentary layers between the basalt flows slow the percolating water, and form perched ground-water bodies beneath the river.

Figure 14 shows the correlation between the hydrograph of well 78 and the discharge of the Big Lost River 


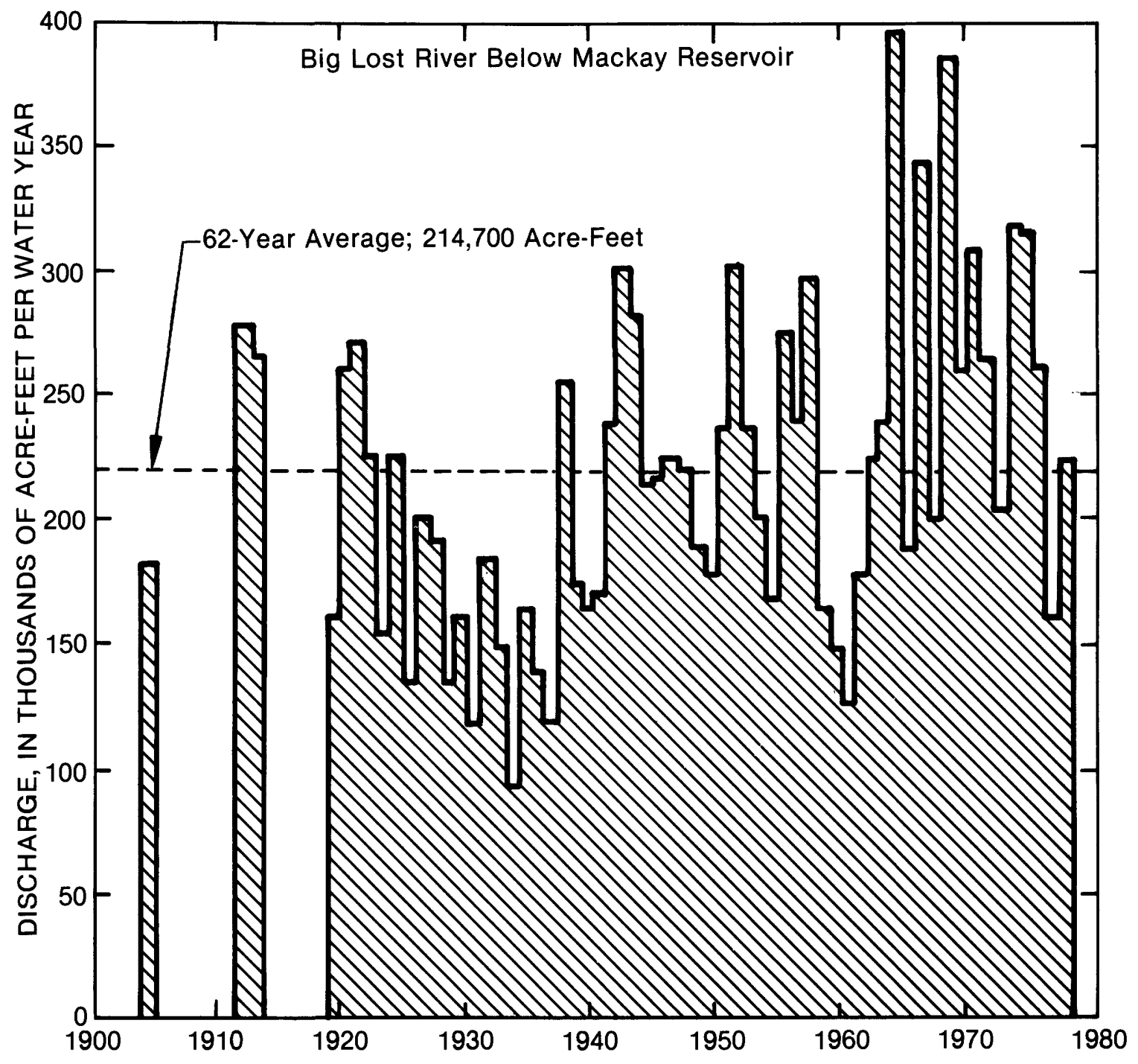

Figure 11. Discharge of the Big Lost River below the Mackay Reservoir.

near the Test Reactor Area. Well 78 is 235 feet from the river and 203 feet deep, and does not penetrate the Snake River Plain aquifer. The perched water level in the well responds rapidly and strongly to changes in river stage. About $4 \frac{1}{2}$ days after flow starts in the river, the water level in well 78 begins an abrupt rise in response to river recharge. The water level has risen almost 100 feet within a few weeks. As stream flow declines or ceases, the perched water level declines abruptly. Declines of 60 to 90 feet have been measured within 3 or 4 months. During much of 1974, 1975, and 1976, the water Fevel in well 78 rose about 80 feet and generally remained at about 100 feet below the land surface. However, following December 1976, the water level has declined to about 190 feet below land surface, with minor exceptions. The only water-level rise in well 78 for the past two years was in early March 1977 , following a small amount of flow in the river due to localized snowmelt. This short-term water-level rise of about 35 feet returned to its original position in less than three months, and the water level continued to decrease gradually over the next year and a half.

Significant amounts of recharge from the Big Lost River have also caused a regional rise of the groundwater level over much of the INEL following several flow events. The water levels in some wells rise as much as 6 feet in a few months following very high flows in the river.

Well 18, site 14 well, and well 6 are located in the central part of the INEL and penetrate the Snake River Plain aquifer. The water levels in these wells are influenced by recharge from high flows of the nearby Big Lost River (fig. 15). The hydrographs of well 18 and site 14 well show very rapid rises of water level following the 


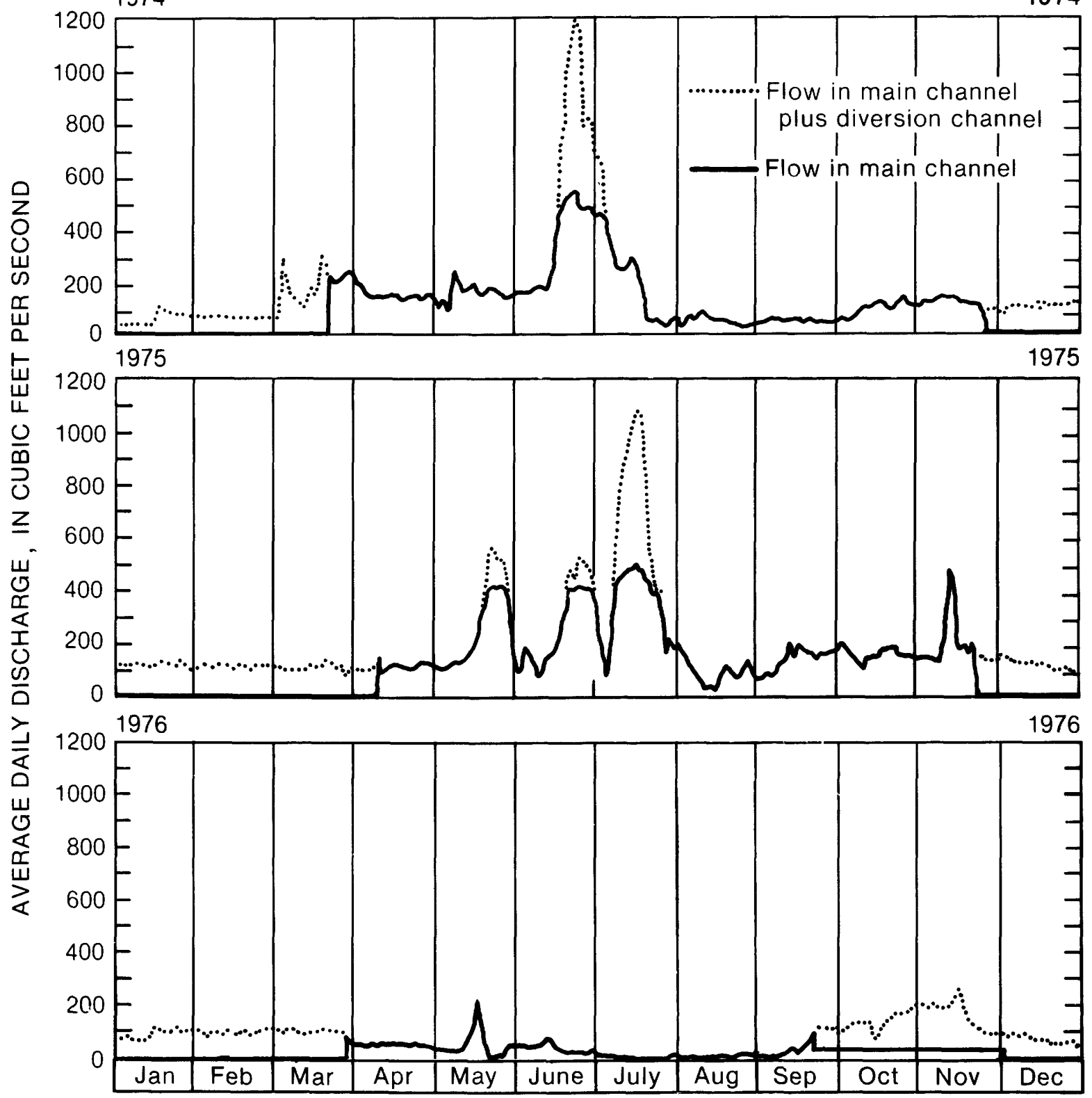

Figure 12. Average daily discharge of the Big Lost River on the INEL during 1974-1976 at the INEL diversion.

recharge from flows in 1965, 1967, 1969, 1971, 1974, and 1975. The water levels in all the wells rose from a near-record low in 1964 to highs of record in 1972 or 1973. Near the beginning of 1976 the water levels were only about 1.5 feet lower than the highest of record. Following this near-record high, water levels have generally declined over the past three years to the low of record near the end of 1978; evidently little recharge was realized from the Big Lost River during this period.

Hydrographs of wells $9,11,8,13$, and 86 (fig. 16) reflect regional water table changes in the southwest corner of the INEL, near the Big Lost River, and show the effects of recharge from the river and from the nearby diversion areas. The effects of high and low flows in the recent years are clearly shown on the graphs. The lowest water levels occurred in 1978 in wells 9,8 , and 86, and in 1964 in well 11. The highest water levels occurred in 1969 in wells 9,8 , and 84, and in 1952 in well 11. The water levels were rather uniform during 1974, 1975, and 1976, but fell rapidly to record and near-record lows near the end of 1978.

Water-level changes in four wells completed in the regional aquifer in the western part of INEL are shown in figure 17. The water levels in these wells are also influenced by recharge from the Big Lost River. The lowest water levels on record occurred in 1964. The highest 


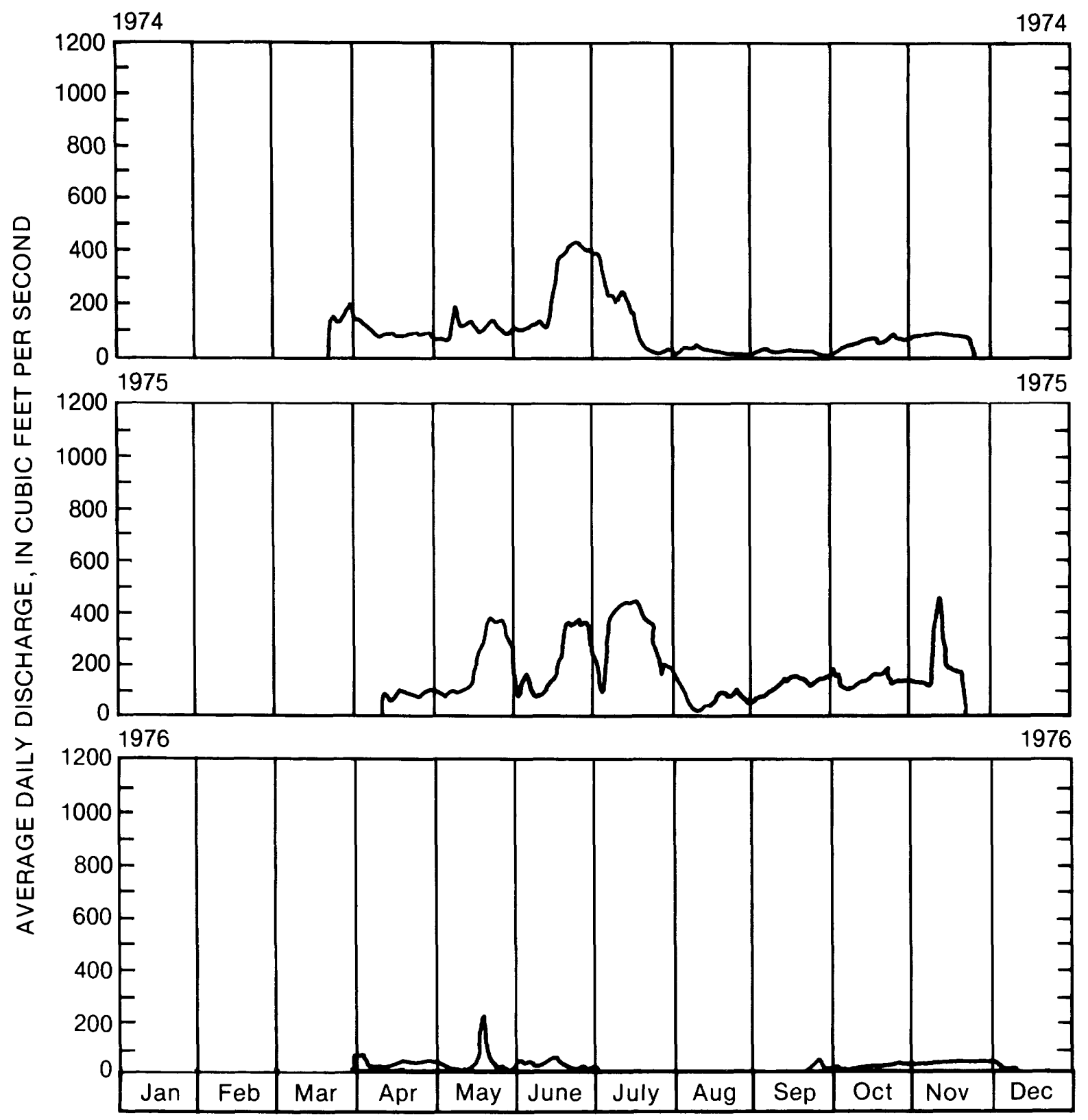

Figure 13. Average daily discharge of the Big Lost River on the INEL during 1974-1976 at the Lincoln Boulevard Bridge near the Test Reactor Area.

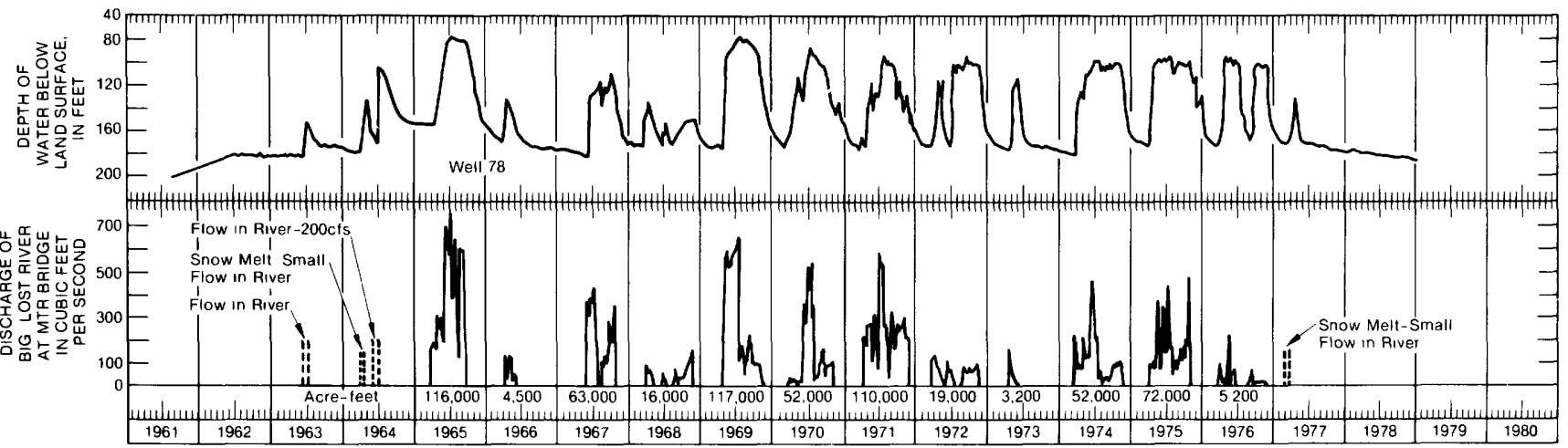

Figure 14. Correlation between water-level fluctuations in well 78 and discharge of the Big Lost River at the Lincoln Boulevard Bridge near the TRA. 


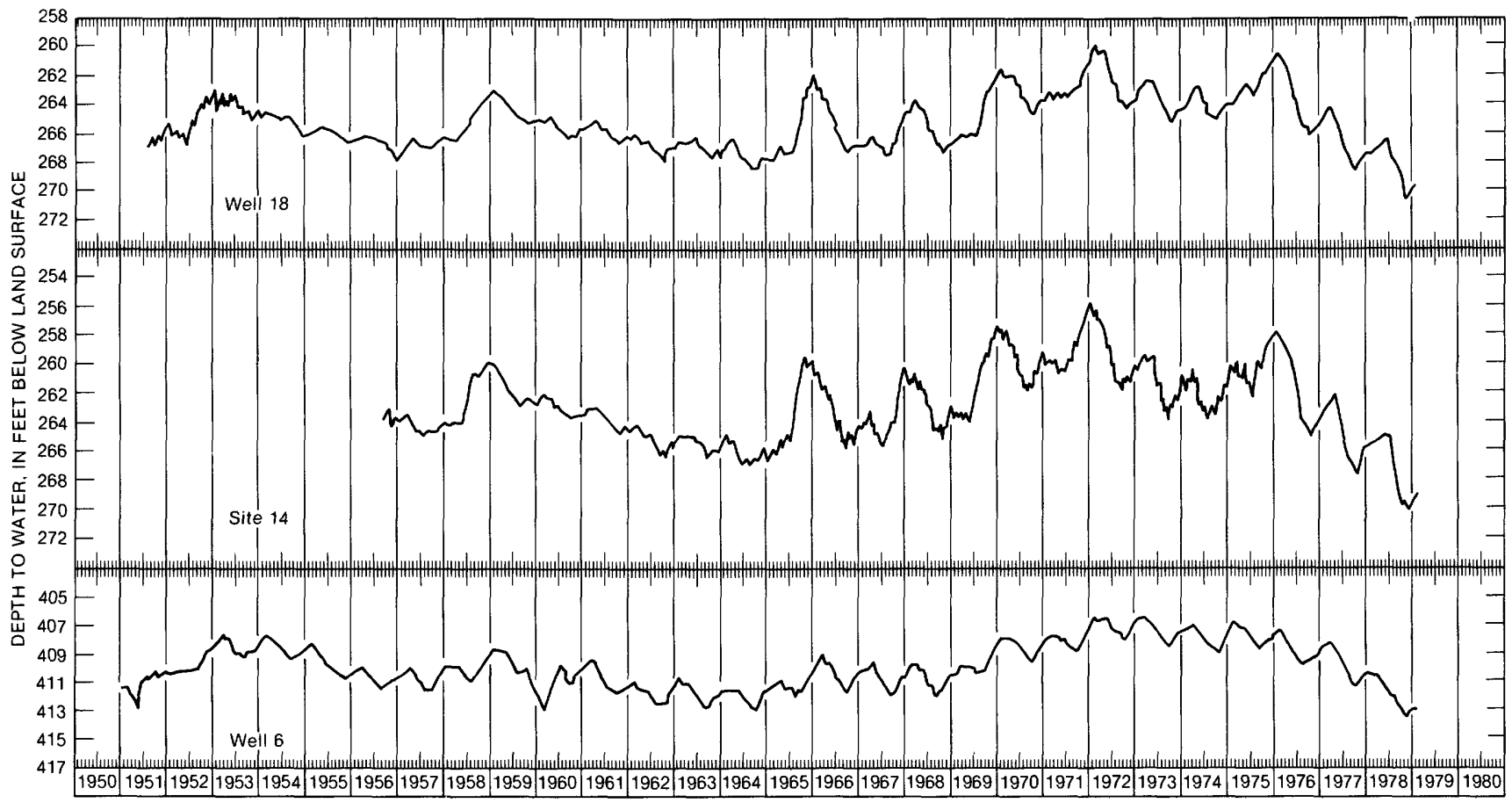

Figure 15. Hydrographs of three wells in the central part of the INEL.

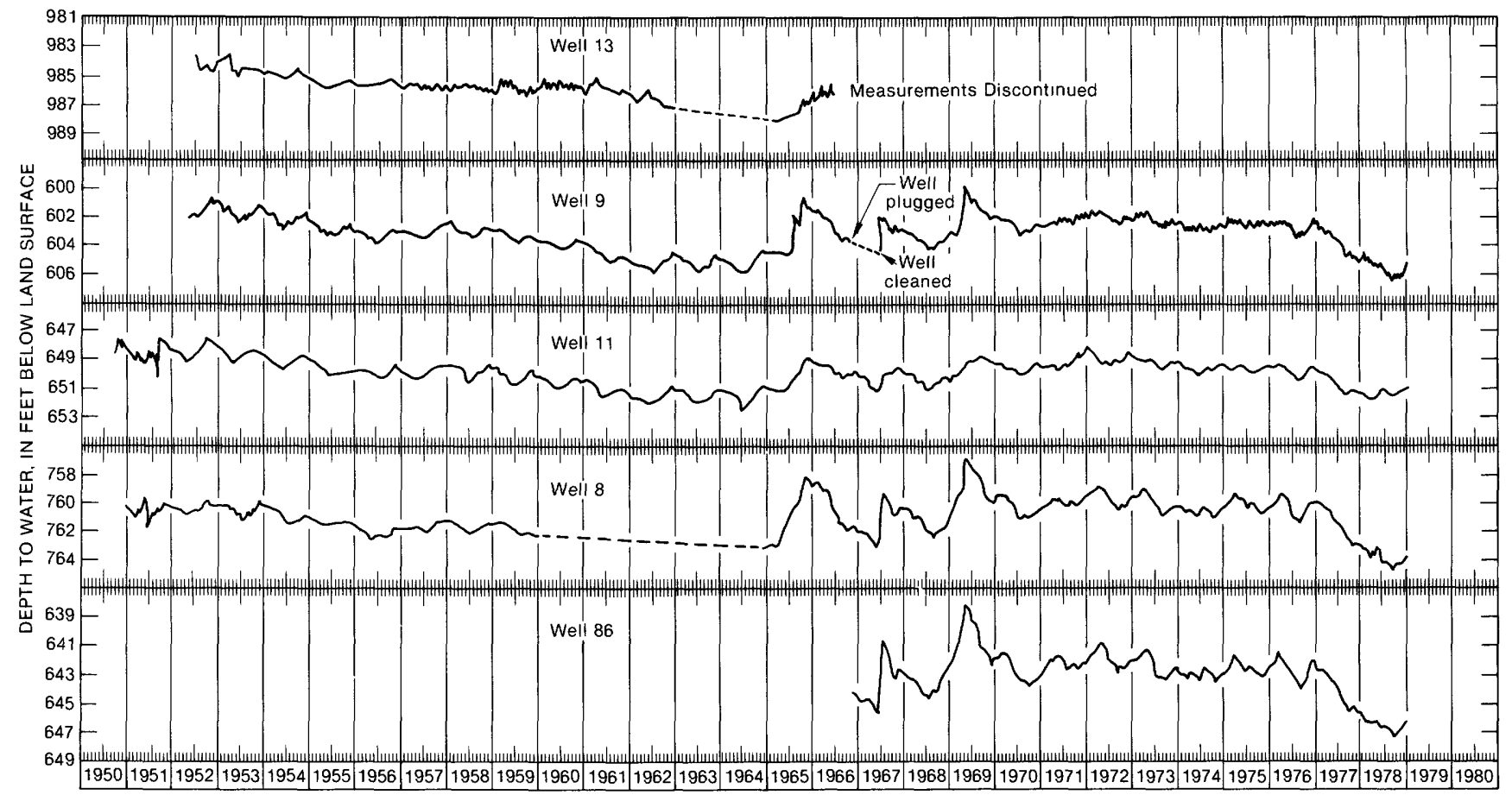

Figure 16. Hydrographs of five wells near the southwest corner of the INEL. 


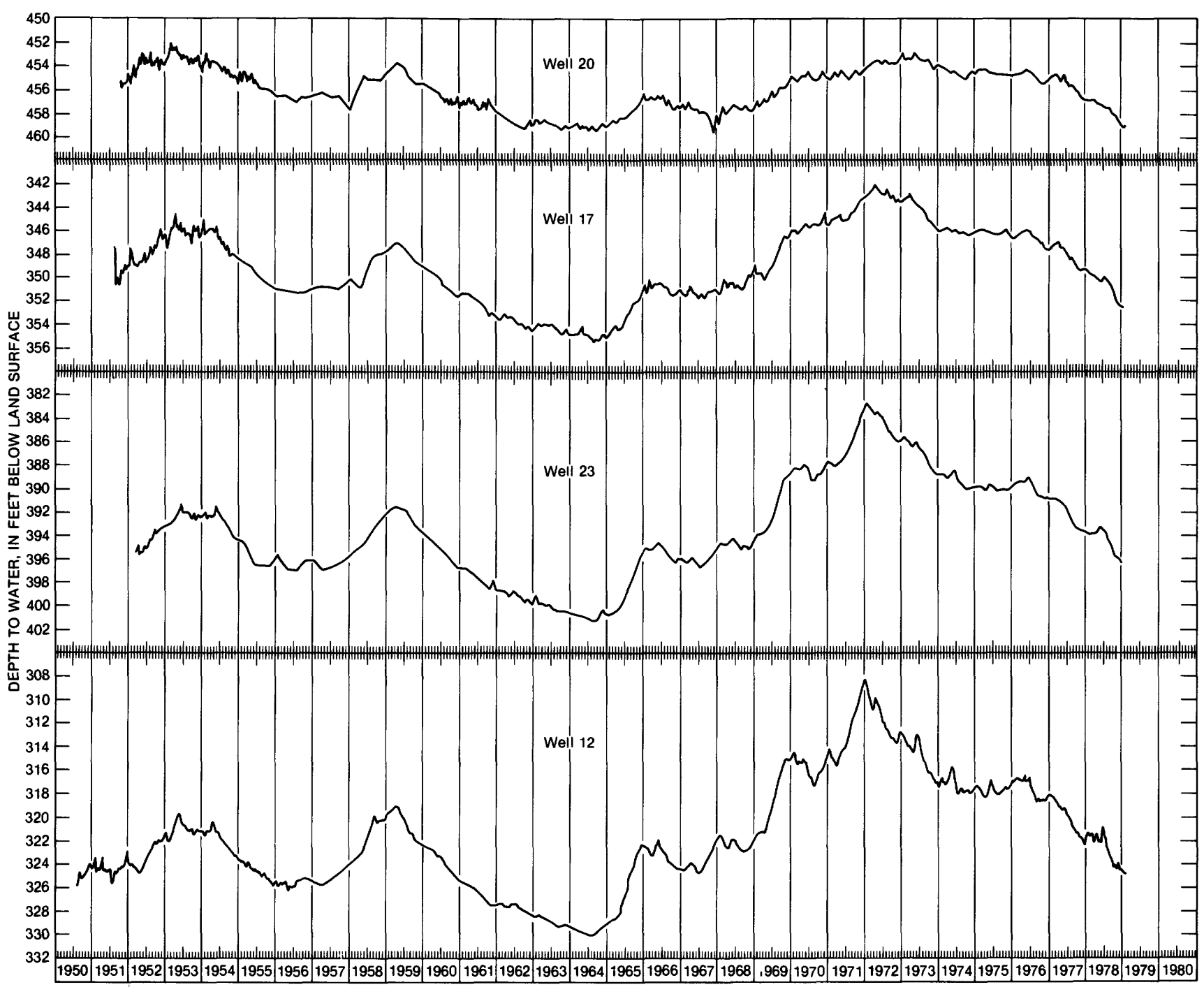

Figure 17. Hydrographs of four wells in the western part of the INEL.

water levels during more than 27 years of record in wells 17,23 , and 12 occurred in 1972.

The water level in well 12 rose 21.5 feet in 8 years from 1964 to 1972 . This is the largest fluctuation of the water level in a well, which taps the Snake River Plain aquifer, that has been measured at the INEL. The water level in well 23 rose 18 feet during this same period, which is the second largest regional rise that has been measured. The water levels have declined from these record highs because recharge from flow in the Big Lost River over the past few years has been negligible.

The water level in well 20 rose only about 6 feet from 1964 to 1972 . Nearby pumping at the ICPP, CFA, and TRA during the period of record may have influenced the water level and prevented the sharp rise that occurred in the other wells penetrating the regional aquifer.

Water levels of the regional aquifer near the southern boundary of the INEL are shown on the hydrographs of wells 1, 2, 14, and the Cerro Grande well (fig. 18). The water levels in these wells reflect regional trends and the relatively minor influences of recharge from the Big Lost River. The water levels in these four wells have fluctuated from 5 to 7 feet during the period of record; they rose from 3 to 5 feet from 1964 to 1973 , and then remained at this 


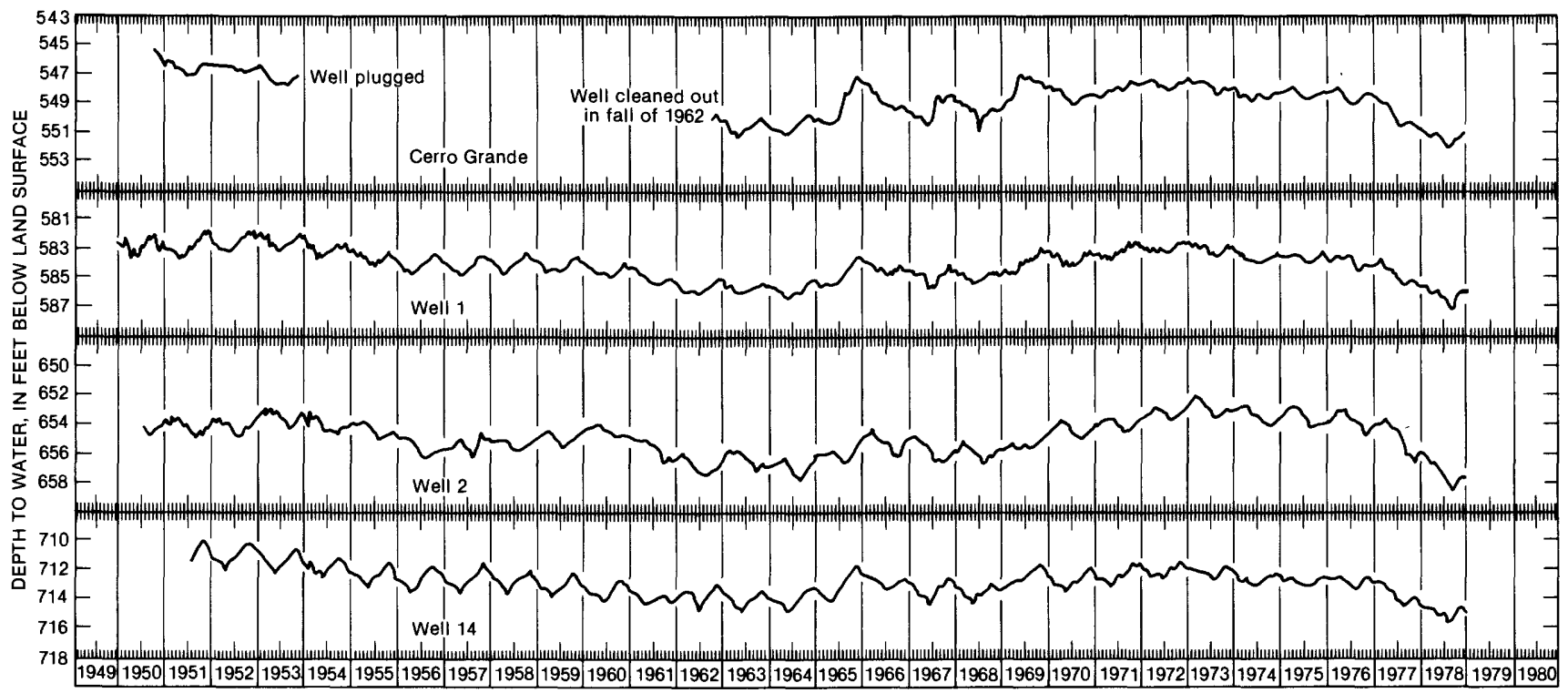

Figure 18. Hydrographs of four wells near the southern boundary of the INEL.

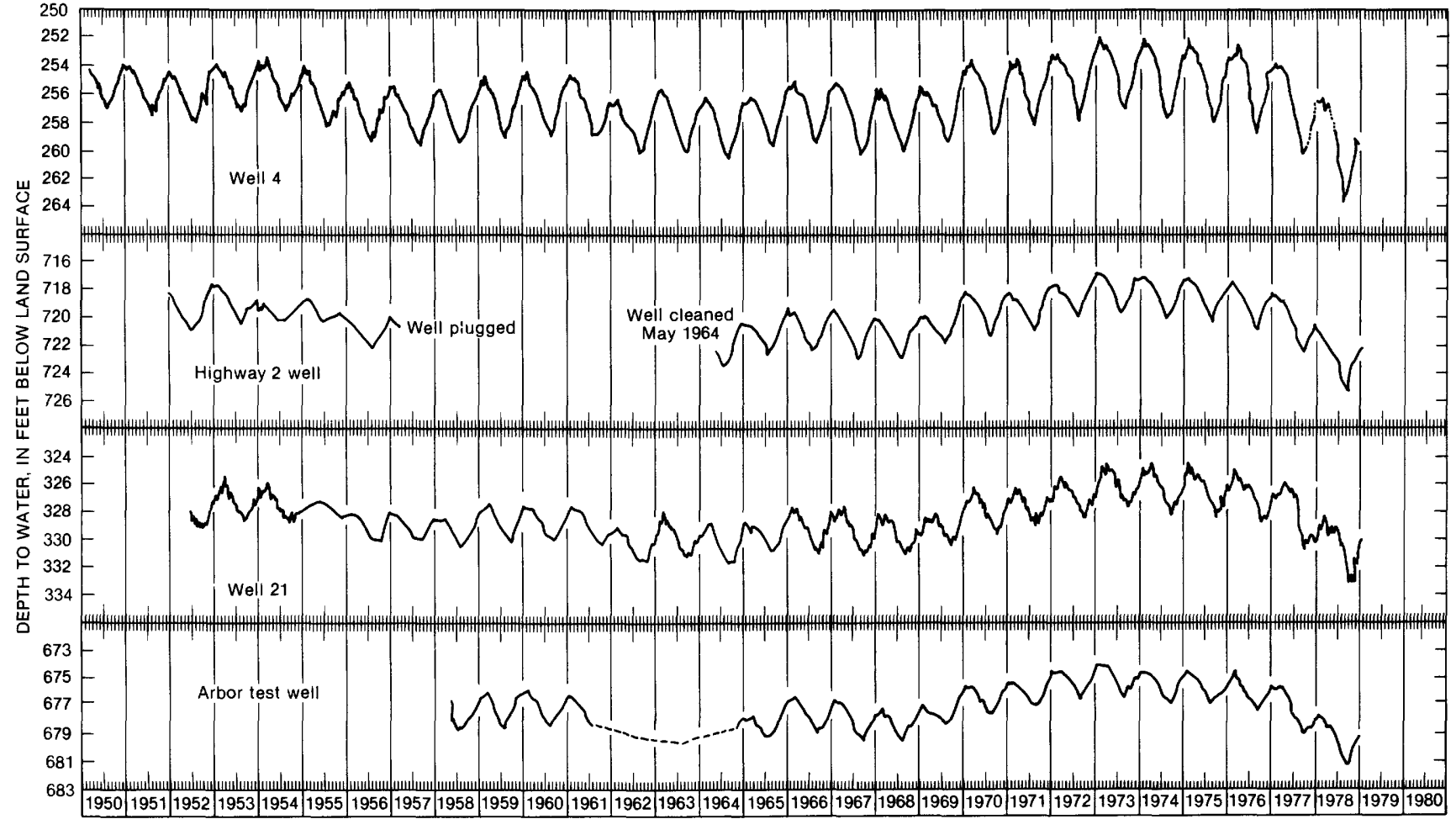

Figure 19. Hydrographs of four wells in the eastern part of the INEL.

relatively high position until a gradual decrease was recorded by the end of 1976. Water levels declined to record lows in 1978 because of little or no recharge from the Big Lost River.

Figure 19 shows hydrographs of well 4, Highway 2 well, well 21, and Arbor Test well, located near the east- ern boundary of the INEL. The highest water levels during the period of record for these four wells occurred in 1973, and the lowest water level was in 1978. The range of water-level fluctuations was from 7 to 11 feet. The water levels have a cyclic annual fluctuation of about 2.5 to 6.5 feet, with the maximums usually in January or 


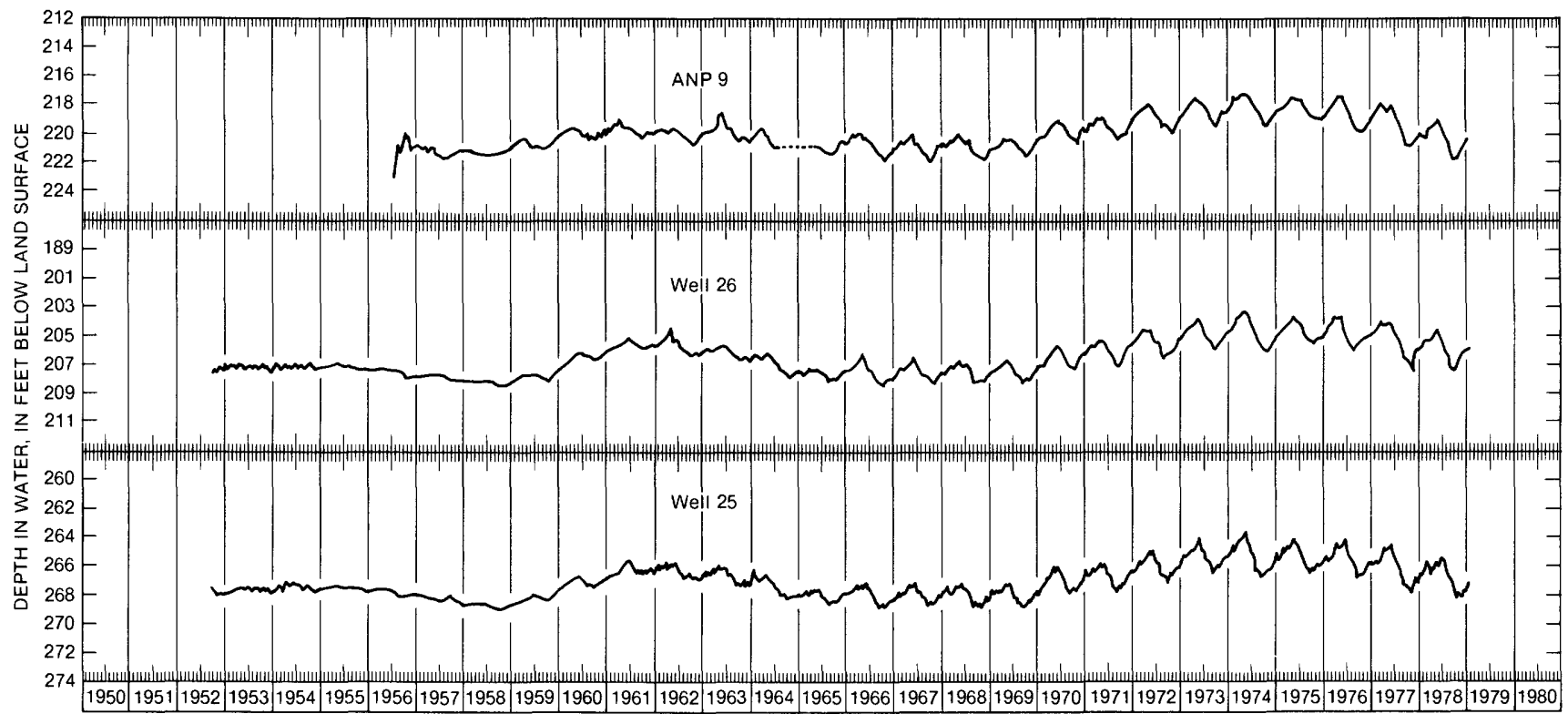

Figure 20. Hydrographs of three wells in the northern part of the INEL.

February and the minimums in July, August, or September.

The changes in water levels in these four wells apparently result in recharge changes from Mud Lake and variations in underflow from the northeastern part of the Snake River Plain. The water levels in 1974, 1975, and 1976 were very near the highest record, and again, due to diminished recharge from all available sources, rapidly declined to the low of record in 1978.

Water levels in the northern part of the INEL are shown on the hydrographs for wells 25,26 , and ANP 9 (fig. 20). Wells in this area are influenced by recharge from Birch Creek and other streams to the northeast. The total fluctuation of the water level for the period of record for these wells ranged from 4 to 5 feet. The annual fluctuation was from 1 to 2.5 feet. The highest water levels of record occurred in 1974 and the lowest water levels occurred in 1966 or 1967, with near record lows being recorded in 1978. From 1969 to 1974 the average water levels rose about 3 feet. These high levels were maintained over the next two years with only a slight decline registered by early 1977 . Peak levels declined more severely in 1978 and minimum readings were near record lows later that year.

Due primarily to high flows in the Big Lost River and resultant recharge, water levels in 17 wells tapping the Snake River Plain aquifer at the INEL were the highest of record in 1972, 1973, or 1974. However, the water level changes in the wells are influenced by the combined effects from all sources of recharge, discharge, and aquifer boundary conditions.

\section{WASTE DISPOSAL}

Liquid low-level radioactive wastes and dilute chemical wastes have been discharged to the subsurface at the TRA since 1952 through a disposal well and ponds, and at the ICPP since 1953 through a deep disposal well.

\section{Test Reactor Area}

The TRA utilizes four disposal systems to dispose of nearly 470 million gallons of waste water annually (fig. 21). Low-level radioactive wastes are discharged to three seepage ponds, constructed in 1952, 1957, and 1964 respectively. These ponds receive more than 40 percent of the total liquid waste. The waste percolates to the Snake River Plain aquifer, 450 feet below the land surface. Chemical wastes are discharged to another seepage pond. Two seepage ponds are used to dispose of sanitary wastes. Cooling-tower blowdown wastes are discharged to the aquifer through a deep disposal well.

\section{Radioactive Waste Ponds}

The average annual discharge to the TRA radioactive waste ponds has been about 200 million gallons. Figure 22 shows a graph of the discharge from 1959 to 1978. Monthly discharge peaks and several yearly discharge totals are depicted on the graph. The discharge to the ponds was 246 million gallons in 1974, 220 million gallons in 1975, and 220 million gallons in 1976 (fig. 22). The discharge was above average for these years and averaged a little more that 19 million gallons per month. 


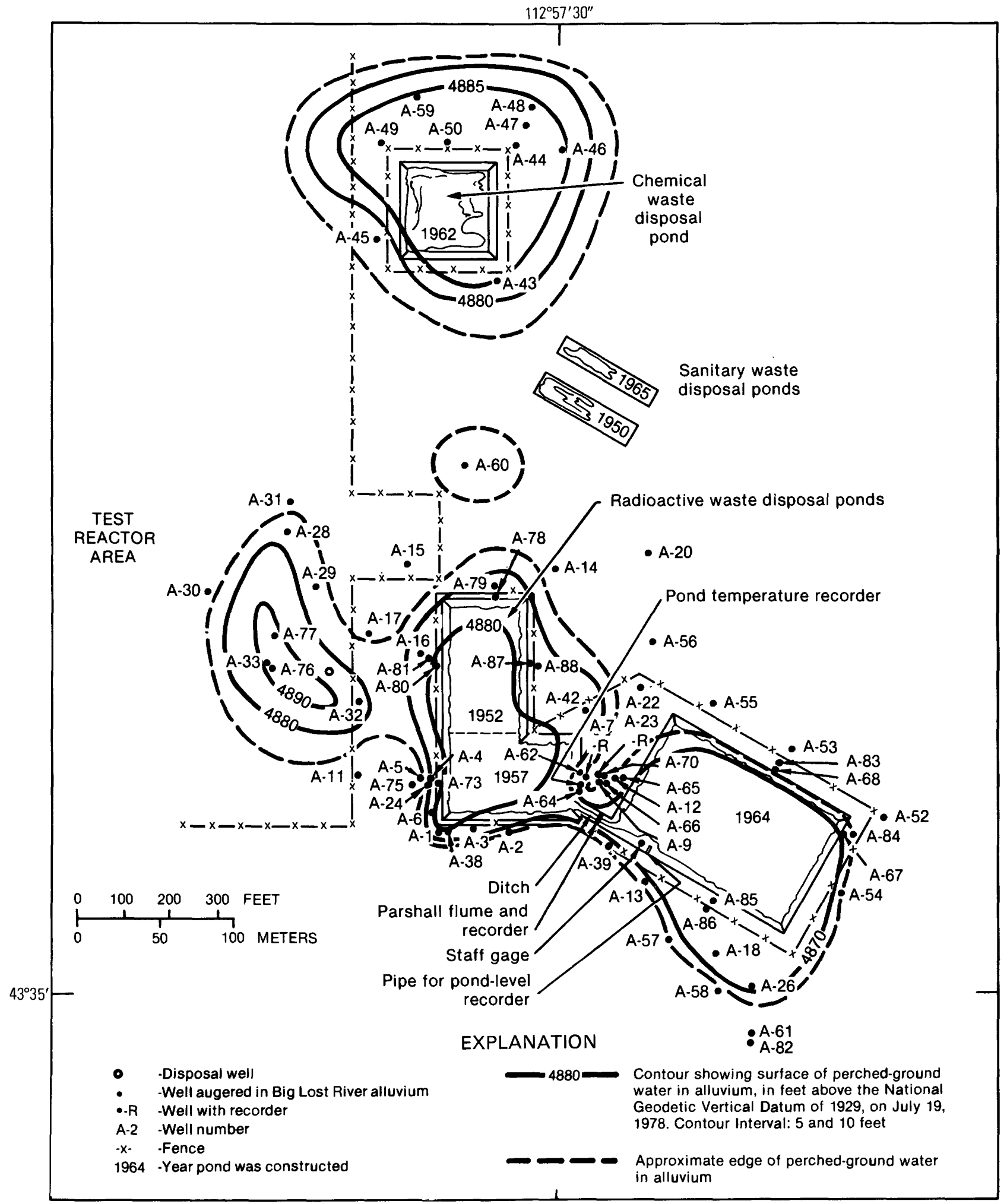

Figure 21. Location of disposal ponds and well, observation wells, and the extent of and water-level contours on the perched ground water in alluvium at the TRA, July 1978. 


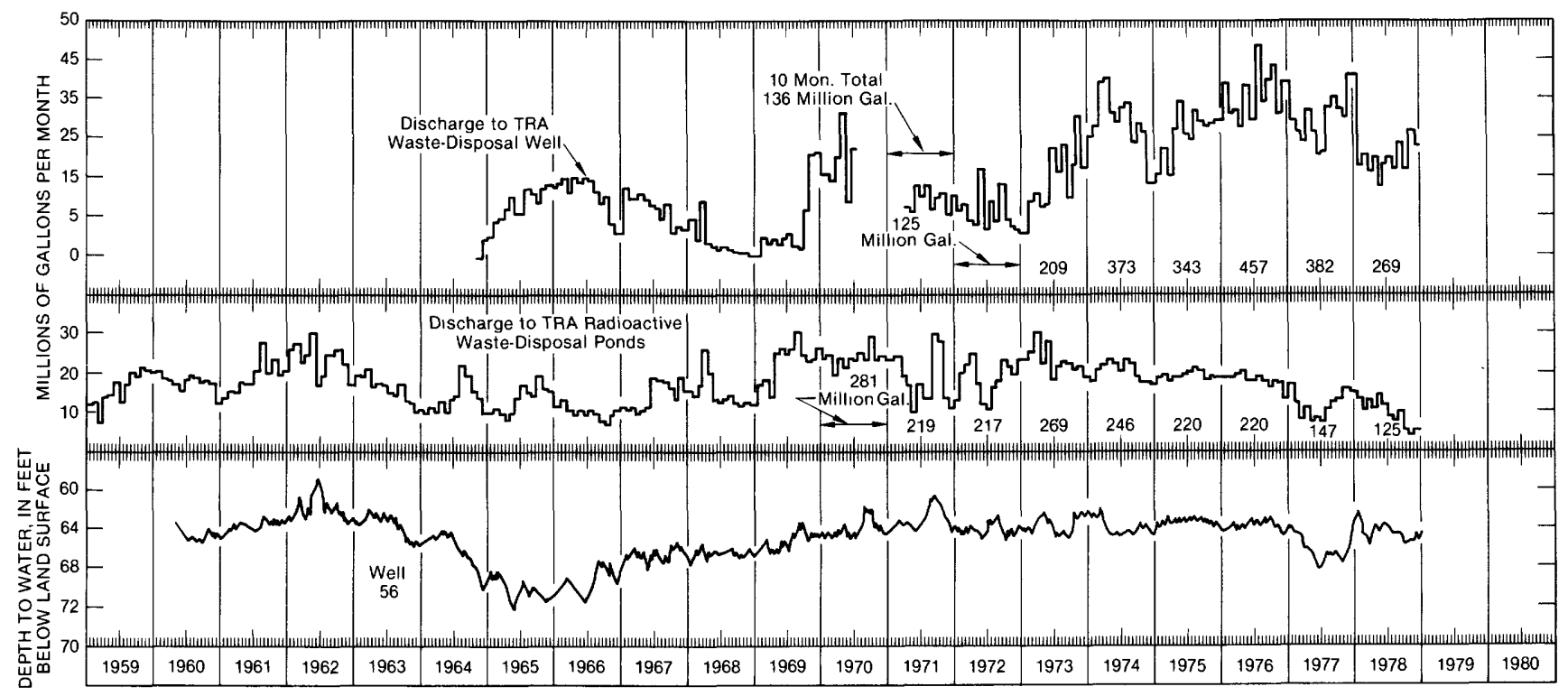

Figure 22. Waste discharged to the radioactive waste ponds and to a deep well at the TRA, and the hydrograph of well 56, which taps the perched ground water in the basalt.

During the next two years, 1977 and 1978, discharge to the ponds was much below normal with 147 million gallons and 128 million gallons being discharged respectively. The daily average for these two years was just over 11 million gallons per month.

The water discharged to the radioactive waste ponds during 1974 to 1978 contained an average of about 2,400 $\mathrm{Ci}$ (curies) per year of activation and fission products. During 1977 and 1978 this average was reduced to about $1,300 \mathrm{Ci}$ (curies) per year as the yearly volume of discharged waste water was drastically reduced. About 70 percent of these products have a short half-life (less than several weeks) and are of little consequence because of their rapid decay. The amounts of some of the nuclides with longer half-lives (more than three years) which have been discharged at the TRA are shown in table 3.

\section{Chemical Waste Ponds}

A pond has been utilized at the TRA since 1962 to dispose of chemical (non radioactive) wastes from ion-exchange system regeneration. The average disposal from 1974 to 1978 was 25.2 million gallons per year; a rate much lower than the preceding 11 year average of 45.6 million gallons per year. During this five-year period, the wastes consisted of a yearly average of $1,359,000 \mathrm{lbs}$ of sulfate and $117,600 \mathrm{lbs}$ of sodium; these yearly amounts are comparable to those listed by Barraclough and Jensen (1976, p. 41) for 1971 to 1973 . Sulphite (33 lbs) and phosphate (17 lbs) were disposed of in 1974 , and their discharge was discontinued thereafter.

\section{Deep Disposal Well}

A disposal well $(1,275$-feet deep) has been used at the TRA since 1964 to dispose of 245 million gallons per year of nonradioactive waste water. The well discharges directly into the Snake River Plain aquifer. The water level is generally about 450 feet below the land surface. Most of the injected water is from cooling-tower blowdown; it contains a yearly average of $532,000 \mathrm{lbs}$ of sulfate and $68,000 \mathrm{lbs}$ of various other chemicals. For several years hexavalent chromium, used as a corrosion inhibitor in the cooling tower, was discharged to the well. Its average concentration in the cooling-tower blowdown was about $2.2 \mathrm{mg} / \mathrm{L}$. This process was replaced by a polyphosphate treatment beginning in October 1972.

Figure 22 shows the monthly discharge to the wastedisposal well from 1964 through 1978 except for a brief period in 1970 and 1971. The discharge increased to a maximum of 457 million gallons in 1976, was 382 million gallons in 1977, and decreased to 269 million gallons in 1978. 


\section{Idaho Chemical Processing Plant}

The ICPP currently discharges low-level radioactive waste and dilute chemical waste directly to the Snake River Plain aquifer through a disposal well 600 feet deep. The natural water level is about 450 feet below the land surface. The average yearly discharge to the well was about 315 million gallons of water for the entire period of record.

Most of the radioactivity of this waste, except for tritium, was removed by distillation and ion exchange before it was discharged into the well. More tritium, in terms of radioactivity, has been discharged than any other waste isotope.

During the period of 1974 through 1978, the ICPP well was utilized to discharge $1,697 \mathrm{Ci}$ of radioactivity in 1,861 million gallons of water. The average curie discharge was $339 \mathrm{Ci}$ per year, and the average volume of water discharge was 372 million gallons per year. Concentrations of radioactivity in the discharge water were very low. A total of $458 \mathrm{Ci}$ was discharged in 1974,46 $\mathrm{Ci}$ in $1975,61 \mathrm{Ci}$ in $1976,736 \mathrm{Ci}$ in 1977 , and $396 \mathrm{Ci}$ in 1978 . About 95 percent of the total activity $(1,605 \mathrm{Ci})$ was tritium of about 0.1 percent $(2 \mathrm{Ci}$ ) was strontium- 90 . The remainder was very low quantities of various other radioisotopes.

\section{DISTRIBUTION OF WASTE}

More than 74 percent of the total waste discharged at the INEL since 1952 has been disposed at the TRA and ICPP facilities. The effects of this disposal have been intensively studied and are discussed in detail in the following sections.

\section{Perched Ground Water Beneath Test Reactor Area}

Five perched-water zones have formed in the subsurface rocks at the TRA because of seepage from disposal ponds. A large zone of perched water has formed in the alluvium beneath and to the west of the radioactive waste- disposal ponds (fig. 21). A very small perchedwater zone has formed in the alluvium north of the radioactive waste-disposal ponds. A zone of perched water has also formed in the alluvium beneath the chemical waste-disposal pond. Another much larger zone of perched water, covering an area of about $0.5 \mathrm{mi}^{2}$, has formed in the basalt beneath the perched zone in the surficial alluvium (fig. 23). This saturated zone in the basalt is perched by a sediment bed approximately 150 feet below land surface.

The water that seeps from the radioactive waste ponds percolates through the surface alluvium and is perched on fine-grained sediment at the base of the alluvial deposit and at the top of the basalt surface, about 50 feet below the land surface. The extent of the perched ground water in the alluvium on July 14, 1978 is shown in figure 21 ; it is about twice the pond area.

The shallow perched water percolates through the fine-grained sediment and into the basalt and moves downward until it reaches another layer of fine-grained sediment that is interbedded with the basalt. This deeper sediment layer, which averages about 50 feet in thickness and is about 150 feet below land surface, also perches the percolating water. As figure 23 shows, the extent of this deeper perched-water zone in the basalt beneath the TRA is much greater than that of the shallower perched zones. The deeper perched water is derived from seepage from

Table 3. Selected radionuclides discharged to the radioactive waste ponds at the TRA

\begin{tabular}{|c|c|c|c|c|c|}
\hline \multirow[b]{2}{*}{ Radionuclide } & \multicolumn{5}{|c|}{ Curies $(\mathrm{Ci})$} \\
\hline & $1974^{1}$ & $1975^{2}$ & $1976^{3}$ & $1977^{4}$ & $1978^{5}$ \\
\hline Tritium & 240 & 260 & 293 & 140 & 127 \\
\hline Strontium-90 & 2.97 & 3.80 & 2.73 & 2.09 & 3.56 \\
\hline Cesium-137 & 3.44 & 2.65 & 1.97 & 2.73 & 6.94 \\
\hline Cobalt-60 & 2.94 & 4.30 & 3.51 & 4.75 & 1.31 \\
\hline Total of all radionuclides & 1,786 & 2,184 & 3,255 & 1,291 & 1,250 \\
\hline
\end{tabular}

\footnotetext{
' S. S. White, 1975b

${ }^{2}$ S. S. White, $1976 b$

${ }^{3}$ S. S. White, 1977 b

${ }^{4}$ S. S. White, $1978 b$

${ }^{5}$ Waste Management Programs, EG\&G Idaho, Inc. 1979b
} 


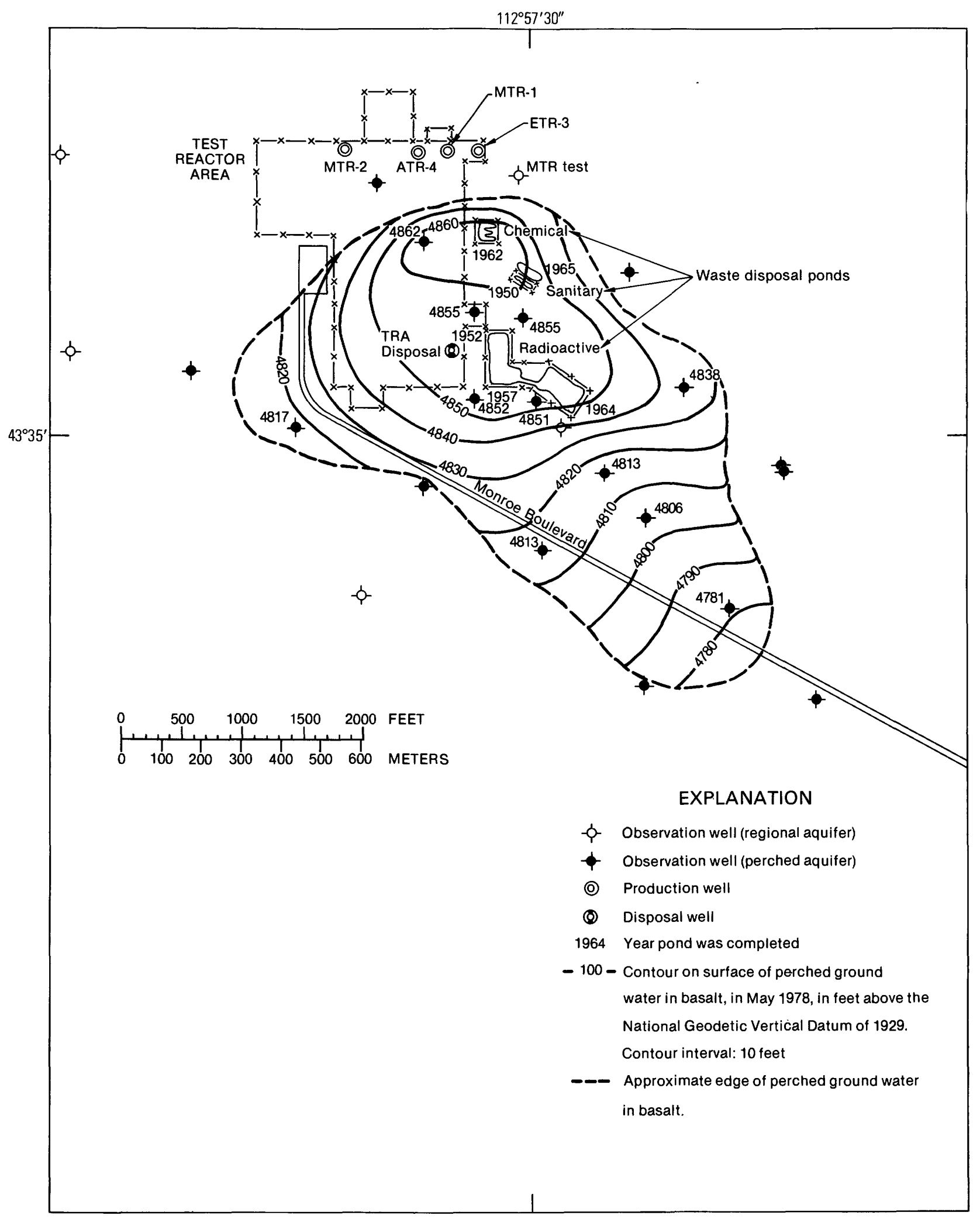

Figure 23. Water level contours on the surface of the perched ground water in the basalt at the TRA, May 1978. 
all of the TRA and from precipitation. The extent of the perched-water zone in the basalt is an area about 5,000 feet by 2,500 feet. The highest water-level contour in figure 23 is 4,860 feet above the geodetic datum, which is about 52 feet below the land surface. The extent and thickness of this large perched-water zone has not changed much in the past 18 years, indicating that the inflow is approximately balanced by the outflow. However, with the sharp reduction in the amount of water discharged to the radioactive-waste ponds from 1976 to 1978 , the lateral extent of this perched-water zone has decreased slightly.

Figure 24 illustrates two hydrographs of wells that tap the perched-water zone in the basalt at the TRA, and a hydrograph of the Materials Test Reactor (MTR) test well, which penetrates the Snake River Plain aquifer. The water level in well 60 has fluctuated a total of 37 feet during the 19 years of record. The water level in well 54 has fluctuated about 18 feet. Comparison of hydrographs for the perched and regional aquifers show that fluctuations in the elevation of the perched-water table are not directly correlated to fluctuations in the regional water table.

Fluctuations of water levels in two additional wells that also tap the perched-water body in the basalt are shown in figure 25 . These water levels reflect recharge from the nearby Big Lost River, especially from record flow in 1965 and 1969, and also reflect changes in the quantity of water discharged to the ponds. The recharge effects from the Big Lost River are shown within a few weeks by the water-level peaks in wells 62 and 71 .

Radioactive and nonradioactive waste products in the perched ground water at the TRA have been studied extensively and are discussed here in detail. Preferably, depictions of the waste products in the perched zone would be time consistent in order to make comparisons; but this is not possible because of insufficient time-correlative data, and therefore waste product concentrations are shown at varying time instances for 1974 through 1978. Other than tritium, chromium-51, cobalt-60, and strontium-90; few additional radioactive-waste nuclides have been detected in the perched-ground water. Most of them are either sorbed on the earth materials, have a very short half-life, or are not discharged in sufficient quantities to be detectable. Figure 26 shows the location of observation wells, the disposal well, production wells, waste disposal ponds, and other geographical features in the TRA vicinity, which will be referred to in the following section.

\section{Tritium}

About $9,500 \mathrm{Ci}$ of tritium has been estimated to have been discharged at TRA from 1952 through 1978, an average of $350 \mathrm{Ci}$ per year. The average discharge of tritium from 1974 to 1978 was $212 \mathrm{Ci}$ per year. Figure 27 shows that from 1962 to 1978 the highest tritium discharge was in 1969 and the lowest was in 1978. Figure 27 also shows the tritium concentrations of water from four wells that tap the perched ground water in the basalt. Concentrations in well water over the latest period of record have remained relatively constant or decreased slightly while the quantity of tritium in waste water discharged to the ponds has decreased significantly over the latter part of this time period.

Figure 28 shows a graph of the average monthly tritium concentrations of waste water in the TRA radioactive-waste ponds from 1961 through 1978. The average monthly tritium concentrations have ranged from a maximum of $1,600 \mathrm{pCi} / \mathrm{mL}$ to a minimum of less than 30 $\mathrm{pCi} / \mathrm{ml}$. The average yearly concentrations of tritium in the pond water has ranged from a high of $816 \mathrm{pCi} / \mathrm{mL}$ in 1966 to a low of $181 \mathrm{pCi} / \mathrm{mL}$ in 1973 . For comparative purposes, the maximum allowable concentration limit of tritium in public drinking water, used as the only source of drinking water for the entire year, is $20 \mathrm{pCi} / \mathrm{mL}$ (U.S. Environmental Protection Agency, 1976). This standard was determined by the Environmental Protection Agency (EPA) in assuming an ingestion rate of 2.0 liters per day of water which would result in a whole-body dose of 4.0 millirem per year of radioactivity. It should be noted that the perched ground water is not used as a drinking water source, or for any other purpose, and its use in the future is extremely remote.

The graphs of the average tritium concentrations of water from two wells that tap the perched water in the basalt at the TRA are included in figure 28 . Well 56, located between the chemical and radioactive-waste ponds (fig. 26), showed a gradual rise in tritium concentrations from 1974 to 1978 , reflecting lower discharges to the chemical-waste ponds and the resultant decrease in their dilution effects. Well 54 is next to the radioactive-waste pond constructed in 1964 (fig. 26), and the tritium concentrations in the disposed waste water are reflected very rapidly by concentrations of tritium in the well water. Figure 29 shows the average tritium concentrations of water from four other wells that penetrate the same perchedwater zone at the TRA. The average tritium concentrations reach high values in 1970 due to large amounts of 


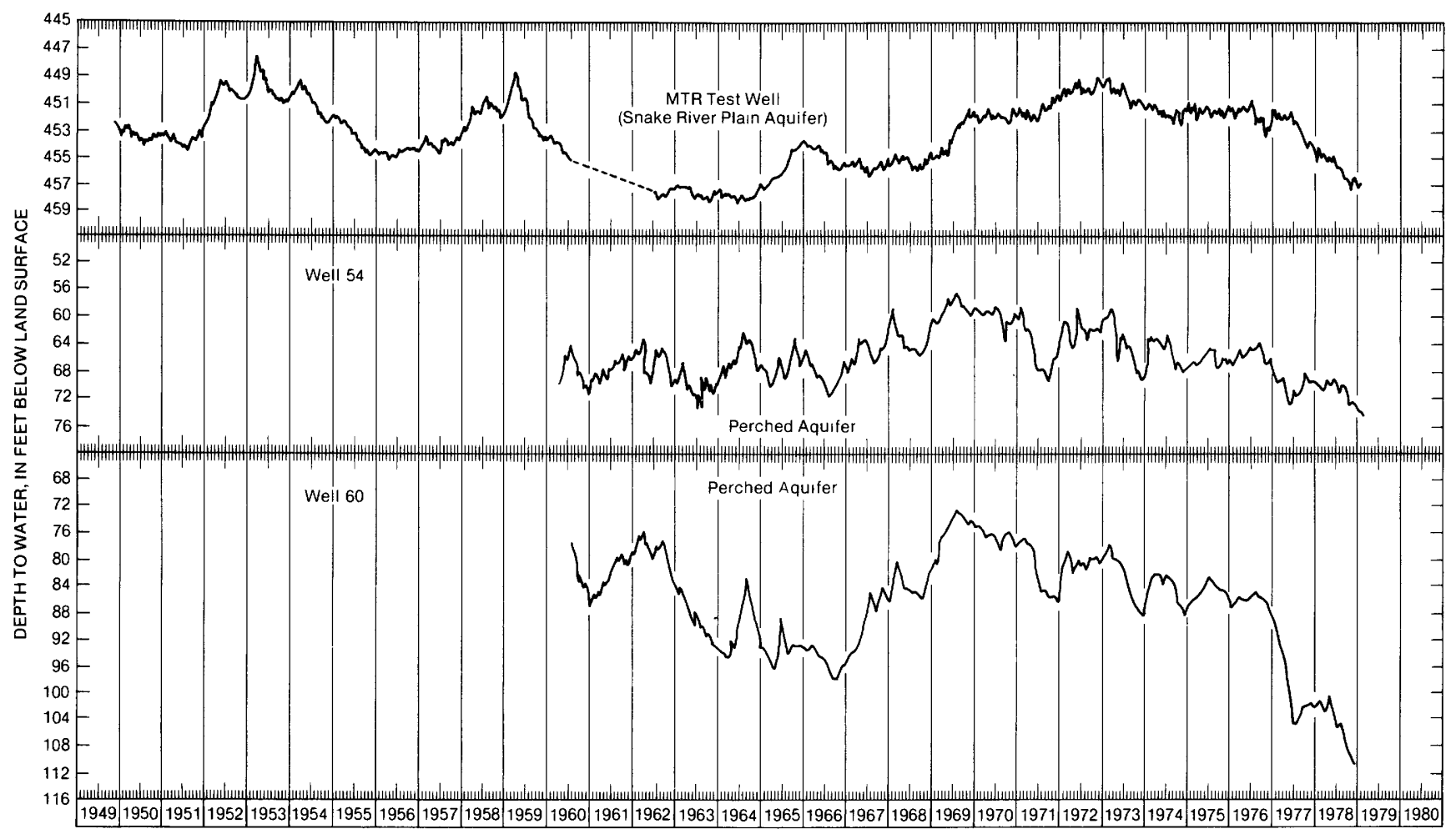

Figure 24. Hydrographs of wells MTR test, 54, and 60.

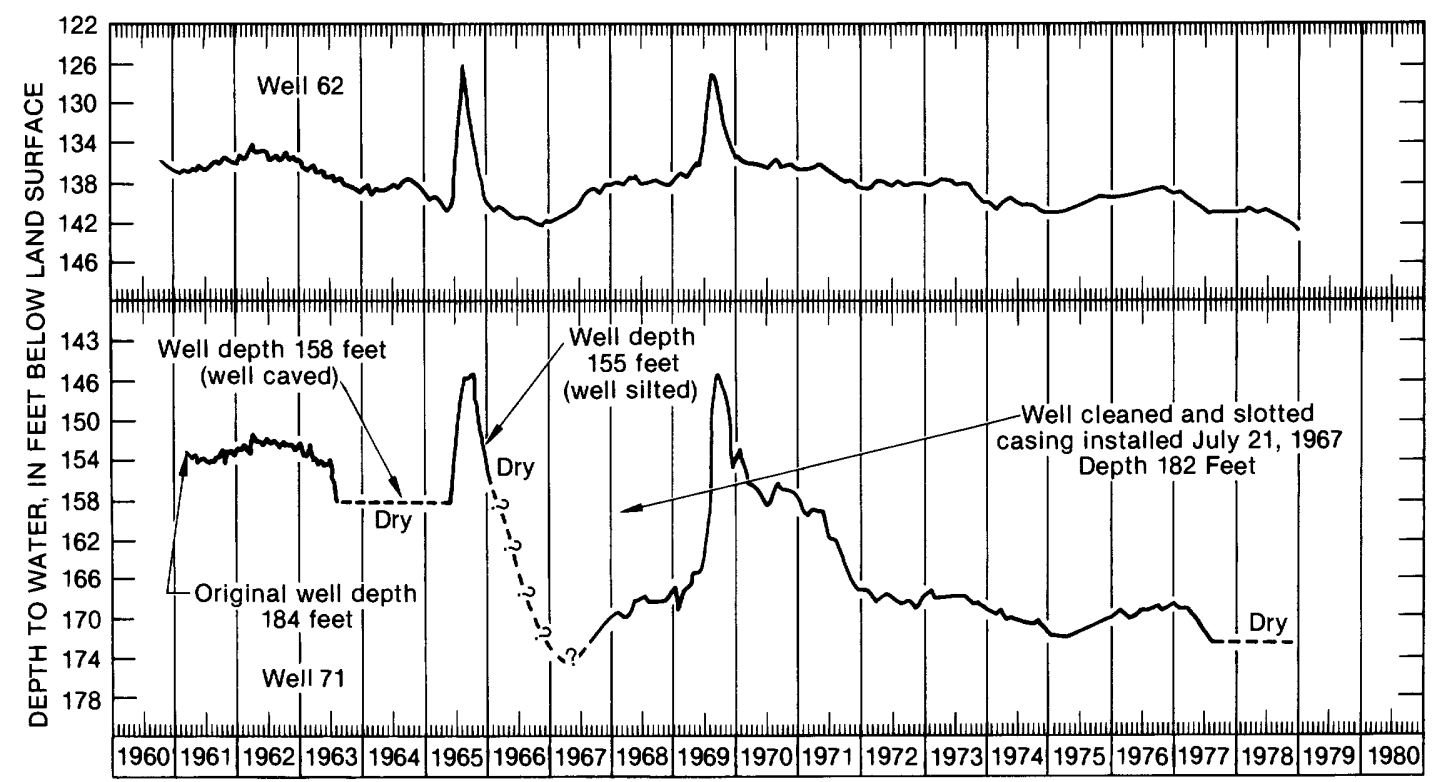

Figure 25. Hydrographs of wells 62 and 71, which tap perched ground water in the basalt at the TRA. 


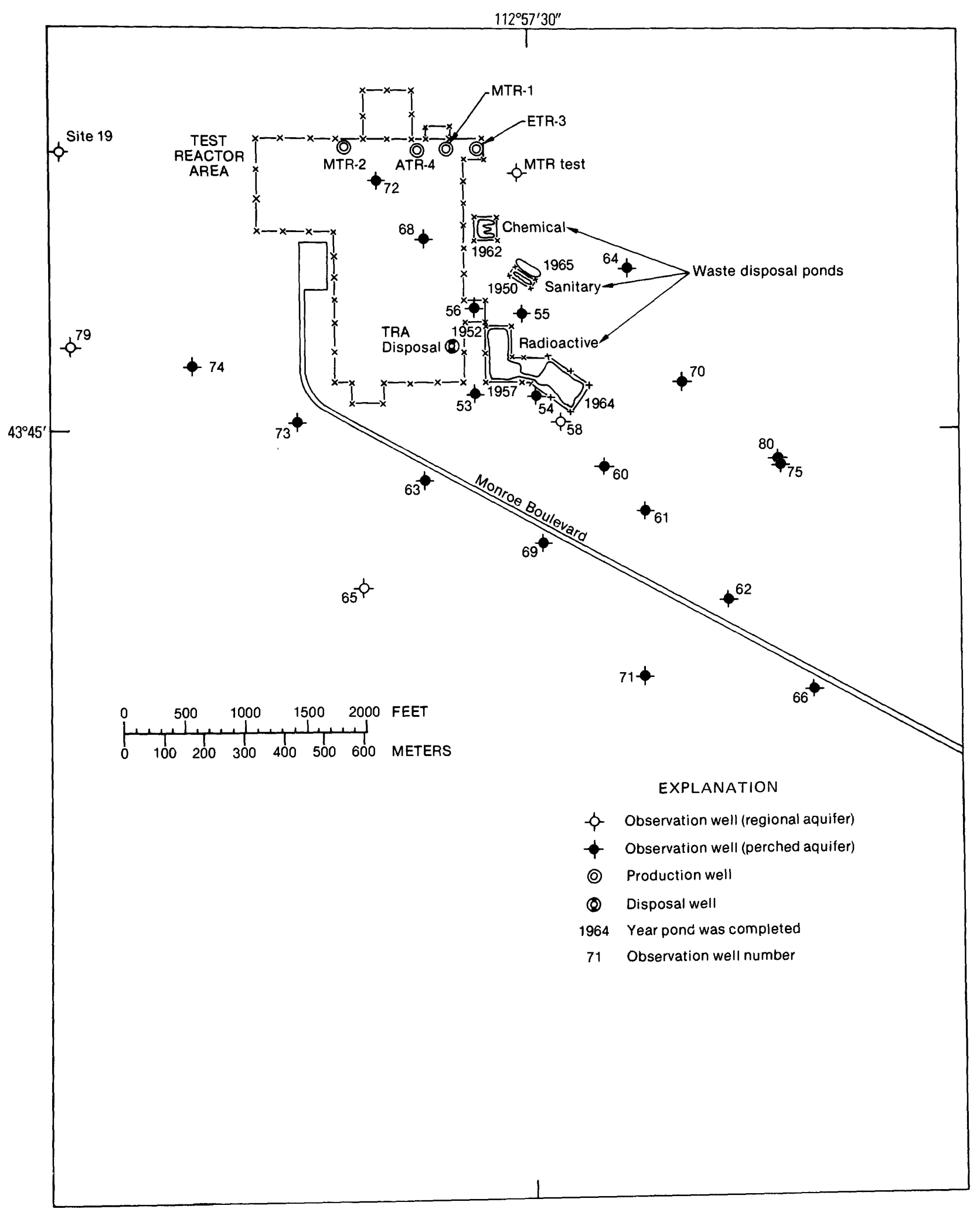

Figure 26. Location of observation wells, production wells, waste disposal ponds, and the disposal well at the TRA. 

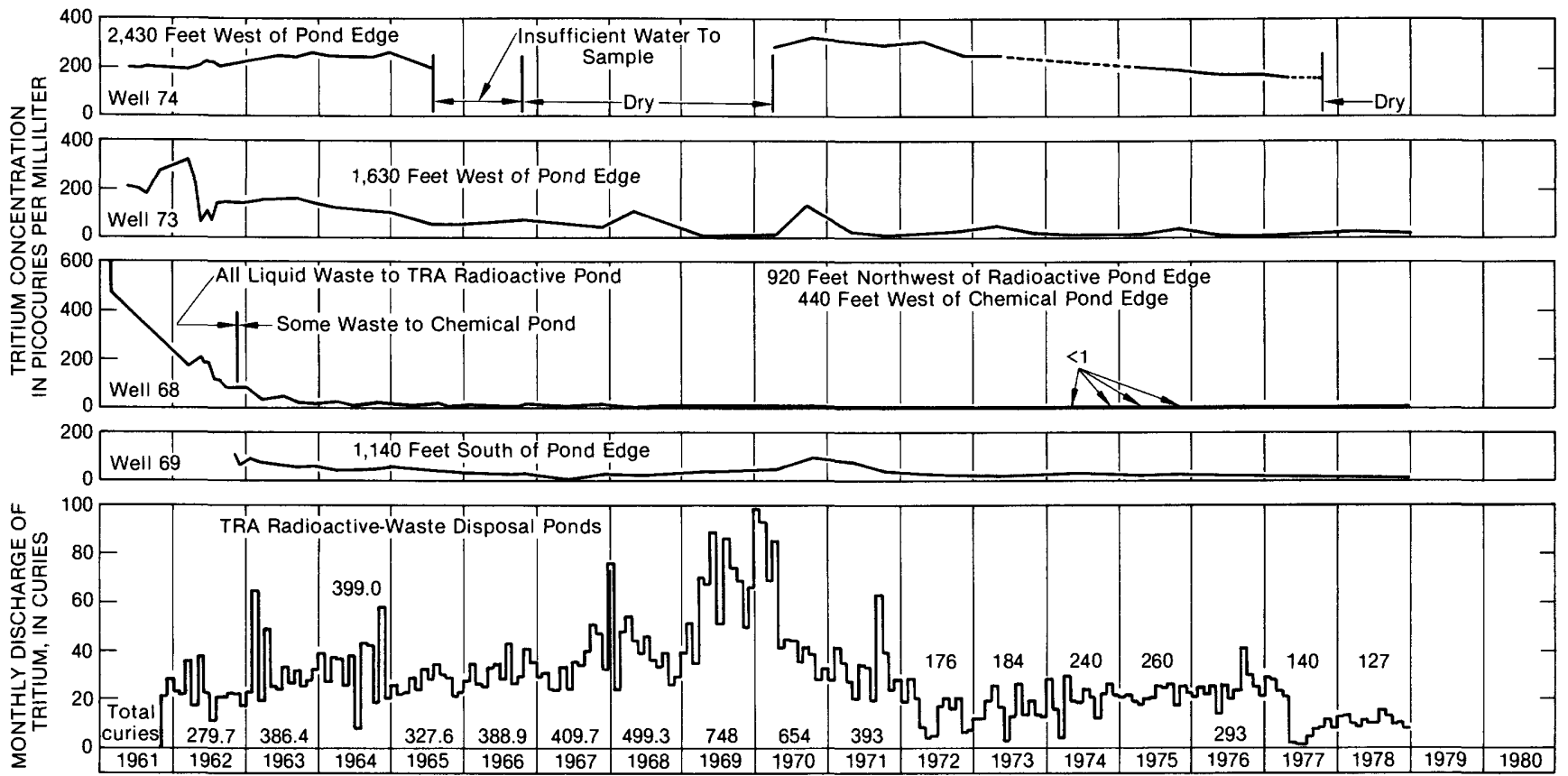

Figure 27. Quantity of tritium discharged to the TRA ponds, and tritium concentrations of water from wells $74,73,68$ and 69 , which tap perched ground water in the basalt.

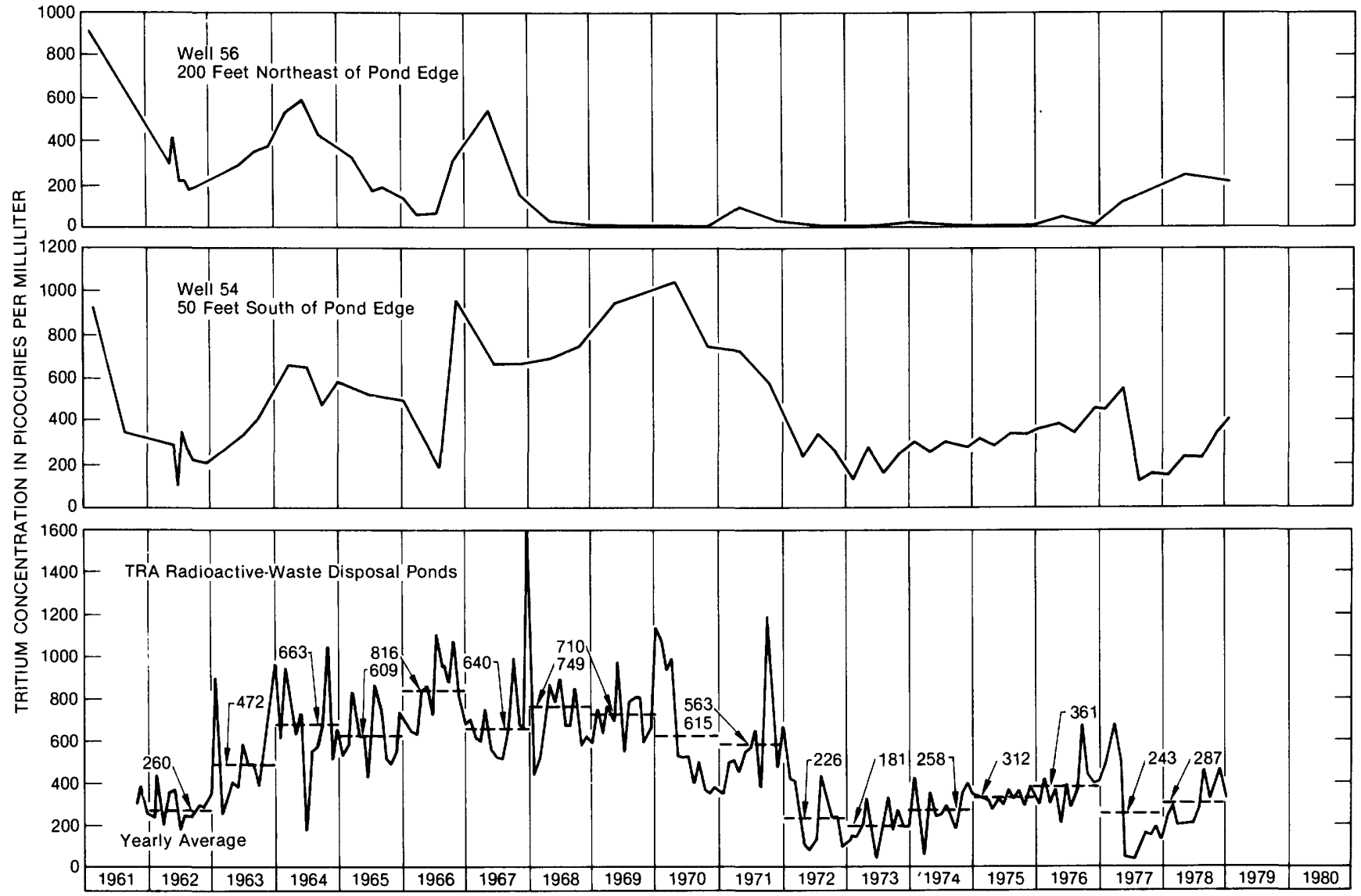

Figure 28. Tritium concentrations of water from the TRA ponds, and from wells 56 and 54 , which tap perched ground water in the basalt. 


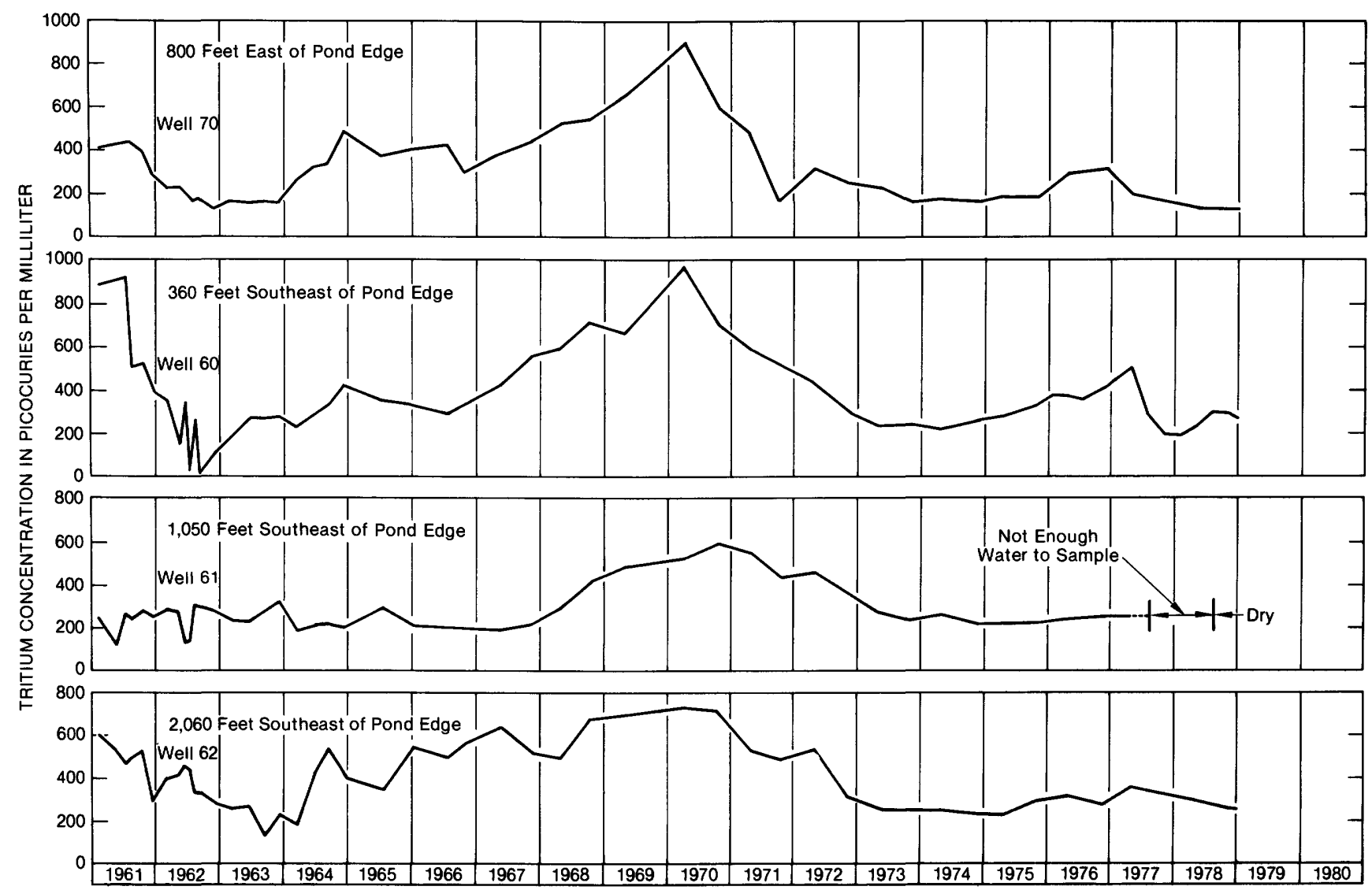

Figure 29. Tritium concentrations in water from wells $70,60,61$, and 62 , which tap perched ground water in the basalt at the TRA.

the nuclide's discharge to the waste ponds in preceeding years; and have generally decreased since then, with only minor fluctuations being registered, because tritium discharge to the waste ponds has generally decreased over the same period.

The tritium concentration in the perched ground water in the basalt for April 1978 is shown in figure 30. The concentrations are highest beneath the radioactivewaste ponds and decrease outward. Changes in concentration in wastes discharged to the ponds produce changes in concentrations in the perched water within months, especially nearer the ponds. The lateral shape of the perched water body has changed little from that depicted for April 1971 by Barraclough and Jensen (1976, p. 37). However, by April 1978 the perched zone (fig. 30) had decreased in size by about 28 percent, and the average concentration of tritium in most well water was less than half of that in April 1971. Tritium is the only radionuclide from the TRA ponds to be detected in water in the Snake River
Plain aquifer. Migration of tritium from the TRA ponds to the regional aquifer has been modeled and described by Robertson (1977); the study indicates that tritium will continue to enter the Snake River Plain aquifer as long as it is disposed of to the radioactive-waste ponds.

\section{Chromium-51}

A total of 7,731 $\mathrm{Ci}$ of chromium-51 was discharged to the radioactive-waste ponds in the period 1.974 to 1978. An average of 1,546 $\mathrm{Ci}$ per year was discharged in waste water which contained an average concentration of $2,204 \mathrm{pCi} / \mathrm{mL}$ of chromium-51. Seventy-five percent of the total radioactivity contained by the waste discharged at TRA in 1974 was chromium-51, and this figure gradually increased to 84 percent in 1978 . Chromium-51 has a half-life of 27.8 days. Figure 31 shows the chromium-51 concentration in perched ground water for April 1977. Since chromium-51 has a relatively short half-life, its 


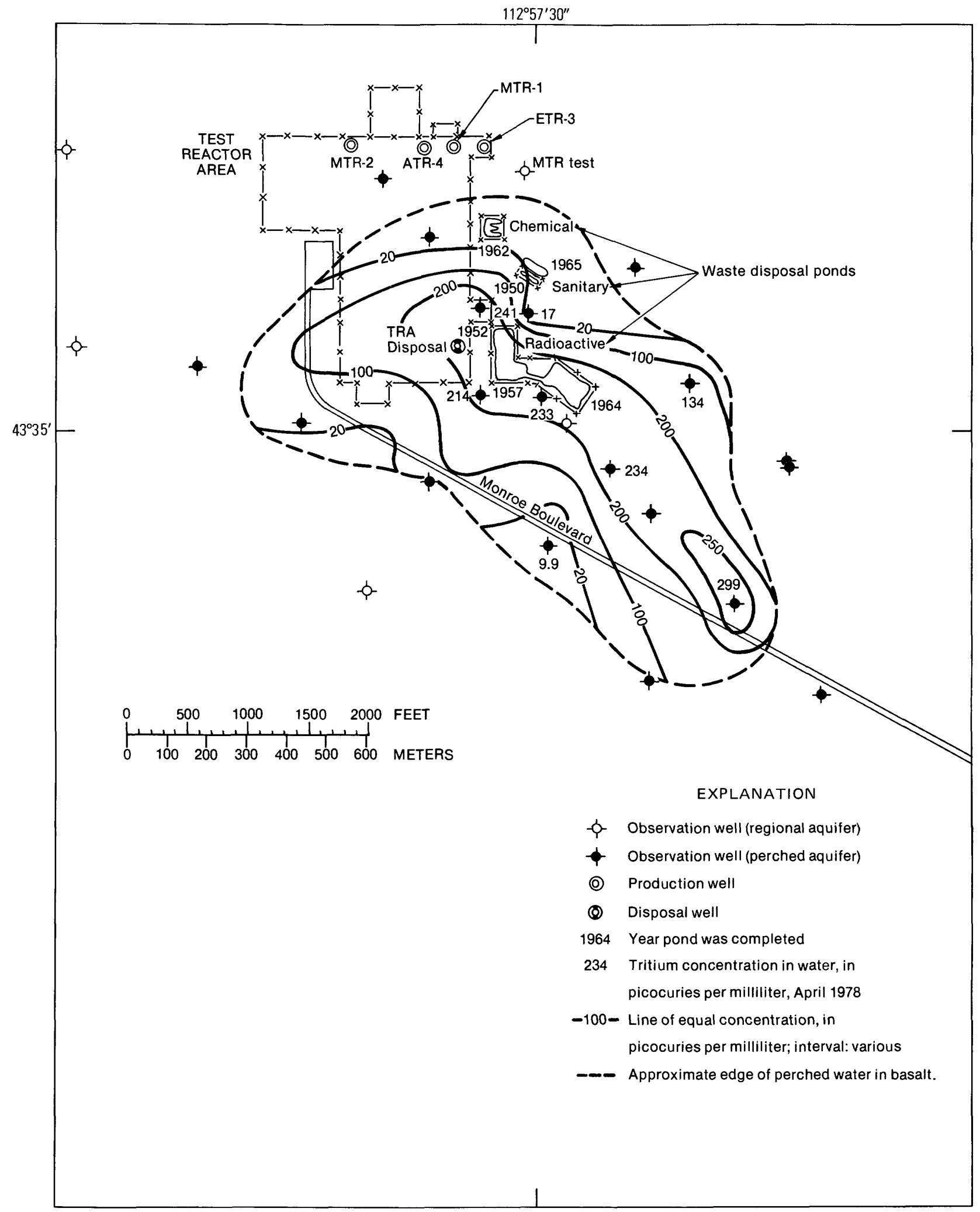

Figure 30. Concentration of tritium in the perched ground water in the basalt at the TRA, April 1978. 


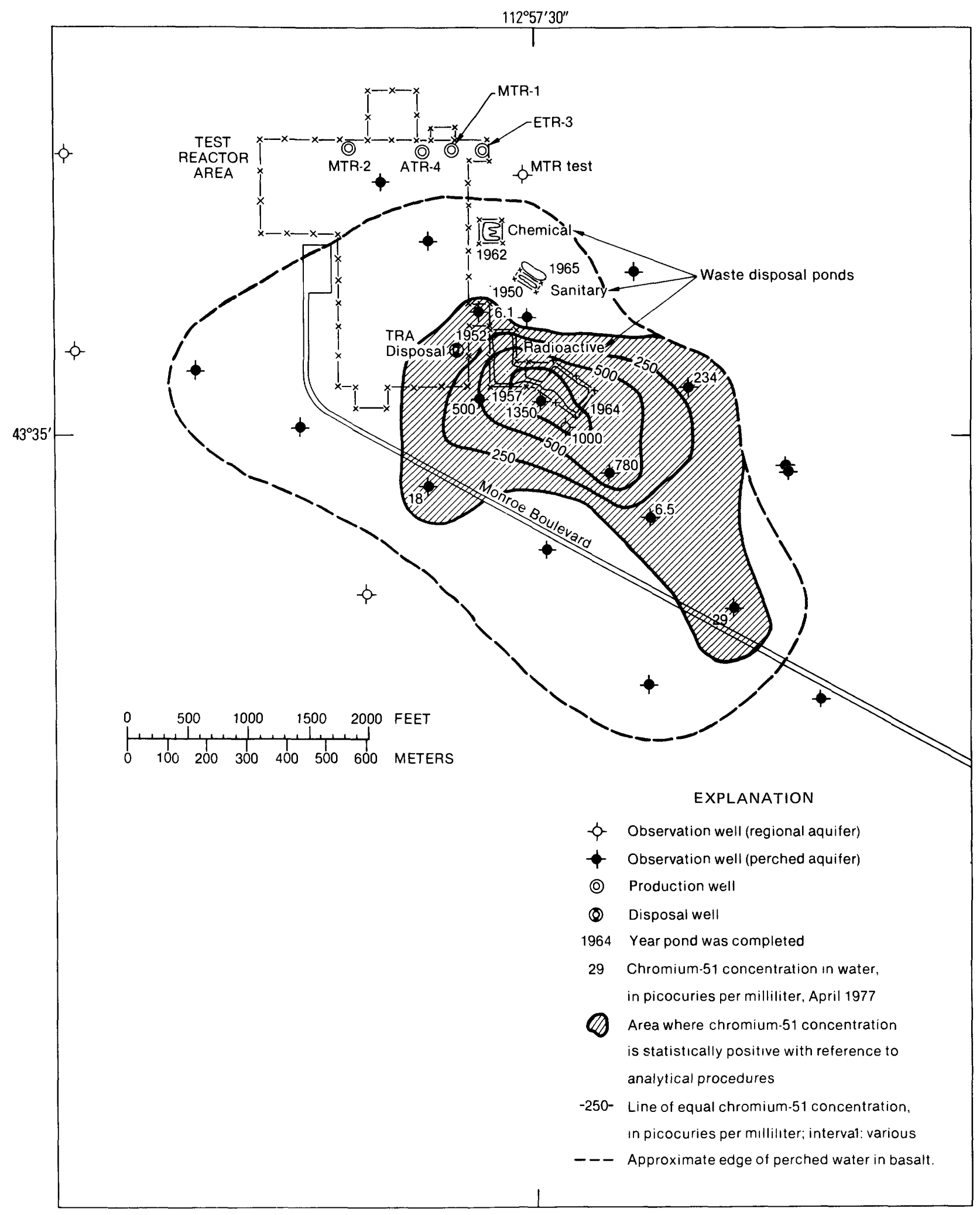

Figure 31. Concentration of chromium-51 in the perched ground water in the basalt at the TRA, April 1977. 
presence in the perched ground water in concentrations approaching the average discharge concentrations indicates rapid movement of waste water to the perched zone. Concentrations are highest in well water contiguous to the disposal ponds but decrease by several orders of magnitude within a very small lateral distance. Chromium-51 has not been detected in the Snake River Plain aquifer, nor is it likely to migrate to the aquifer because of its short half-life.

\section{Cobalt-60}

About $417 \mathrm{Ci}$ of cobalt-60 have been discharged to the TRA radioactive-waste ponds since 1952. This is an average of about $15 \mathrm{Ci}$ per year. During the period from 1974 through 1978 , however, a total of about $17 \mathrm{Ci}$ of cobalt-60 was discharged to the ponds. This is an average of only 3.4 curies per year. The average concentration of cobalt-60 in the discharged waste water was $4.9 \mathrm{pCi} / \mathrm{mL}$. Figure 32 shows the cobalt-60 concentration in the perched ground water in April 1977. The half-life of cobalt-60 is 5.3 years. The lateral extent of cobalt- 60 in the perched ground water in the basalt has increased from that shown by Barraclough and Jensen $(1976$, p. 40) for October 1972, but the concentration of cobalt-60 in the perched ground water has decreased greatly in comparison with the same figure. Evidently the relatively slow decay rate of the radionuclide has kept detectable quantities of cobalt- 60 in the basalt perched zone while the amount and concentration of cobalt- 60 discharged to the waste ponds have decreased for the period 1974 through 1978.

\section{Strontium-90}

About $80 \mathrm{Ci}$ of strontium- 90 has been discharged to the TRA radioactive-waste ponds from 1952 to 1978. This is an average of about $3 \mathrm{Ci}$ per year. The total discharge of strontium-90 from 1974 through 1978 was $15.2 \mathrm{Ci}$, for an average nearly equal to that for the total period of record. The average concentration of strontium- 90 discharged to the TRA radioactive-waste ponds from 1974 through 1978 was $4.4 \mathrm{pCi} / \mathrm{mL}$.

The distribution of strontium-90 outward from the ponds in the perched ground-water zone in the basalt in April 1975 is shown in figure 33. The figure was constructed from the data from five shallow wells. Strontium-90 was not detected in water samples from the other wells. Strontium- 90 can be detected about 1,000 feet outward from the edges of the ponds. Sorption plays an important role in removing the strontium-90 from the perched ground-water zone (Robertson, Schoen, and Barraclough, 1974, p. 108). That portion of the perched ground water in which significant amounts of strontium90 can be detected is similar to that of October 1972 (Barraclough and Jensen, 1976, p. 42), and concentrations within this limited area have remained constant or decreased slightly since that time. Strontium- 90 has a half-life of 28.6 years and concentrations may continue to be relatively constant in the years to come. Strontium- 90 has not been detected in water from the Snake River Plain aquifer near the TRA ponds. The potential for migration of strontium- 90 from the TRA ponds to the regional aquifer was modeled and described in a report by Robertson (1977), who concluded that strontium-90 may reach the Snake River Plain aquifer in the future if preferential vertical flow paths exist in the unsaturated zone beneath the perched aquifer, if the strontium- 90 distribution coefficients of the sediment layers are much lower than estimated, or if the sedimentary layers are much thinner than expected. This conclusion is also based on the premise that strontium- 90 discharge to the waste ponds remains constant at the current rate.

\section{Cesium-137}

Approximately $129 \mathrm{Ci}$ of cesium-137 was discharged to the disposal ponds at the TRA over the period of 1952 through 1978, for an average of about $5 \mathrm{Ci}$ per year. The discharge of cesium-137 totaled $17.7 \mathrm{Ci}$ from 1974 through 1978 for an average of approximately 3.5 Ci per year. Cesium-137 has a similar half life (30.2 years) to strontium-90; and because of this and other similarities such as quantities disposed, the distribution of cesium-137 in the perched ground water could be expected to be similar to the distribution of strontium- 90 . However, cesium-137 has never been detected in a water sample from the perched ground water in the basalt. Cesium-137 is strongly sorbed to the minerals of the alluvial sediments and sediments within the basalt and is removed before reaching wells in the perched-water body (Robertson, Schoen, and Barraclough, 1974, p. 108).

\section{Specific Conductance}

The chemical-waste pond water has a high specific conductance because of the large amount of dissolved chemicals discharged to it. Figure 34 shows the specific conductance of samples taken from the perched ground water in the basalt in April 1978. The specific conductance of water from the well nearest the chemical-waste pond was 3,300 micromhos per centimeter (fig. 34). At a greater distance from the pond, the perched water had a 


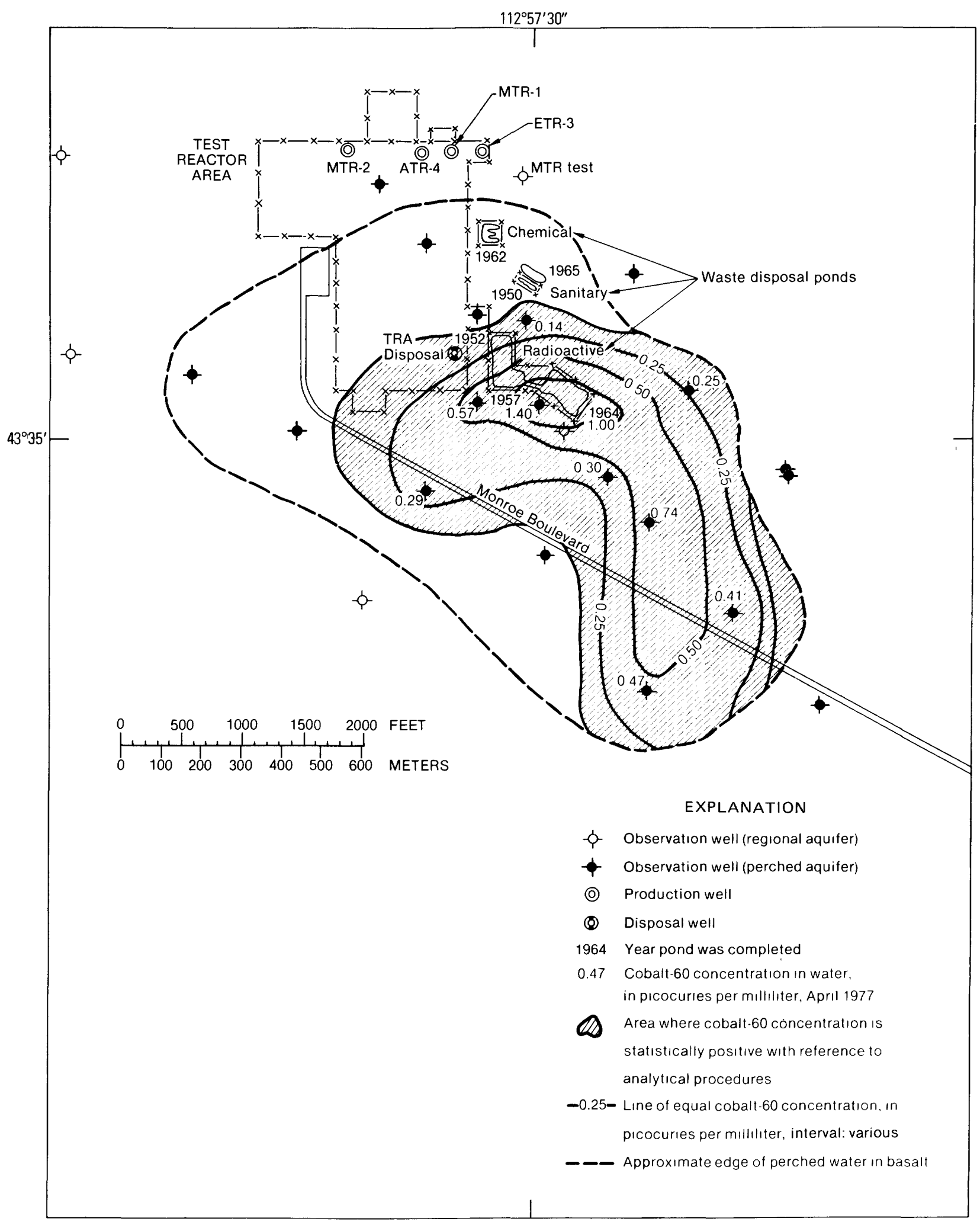

Figure 32. Concentration of cobalt-60 in the perched ground water in the basalt at the TRA, April 1977. 


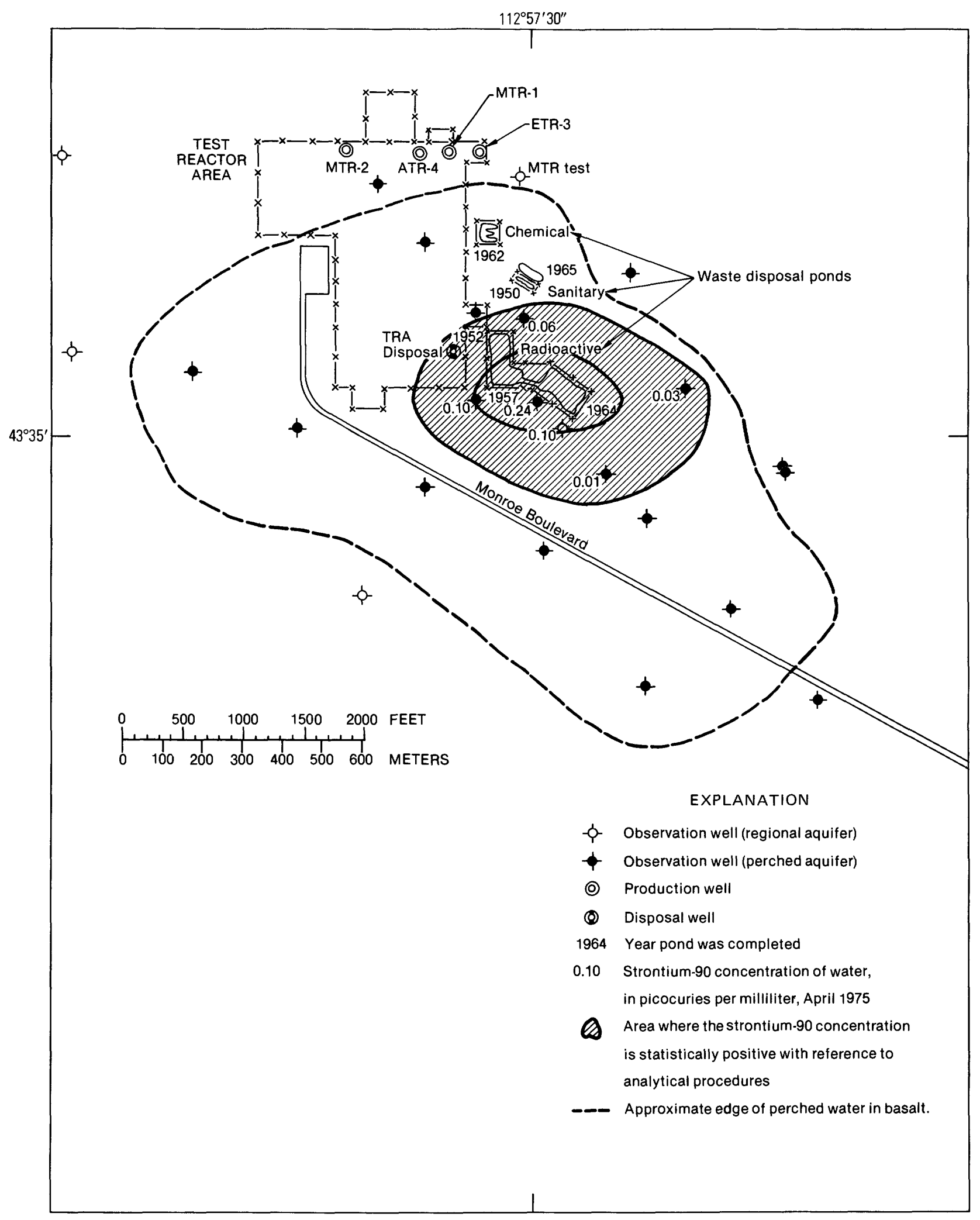

Figure 33. Concentration of strontium-90 in the perched ground water in the basalt at the TRA, April 1975. 


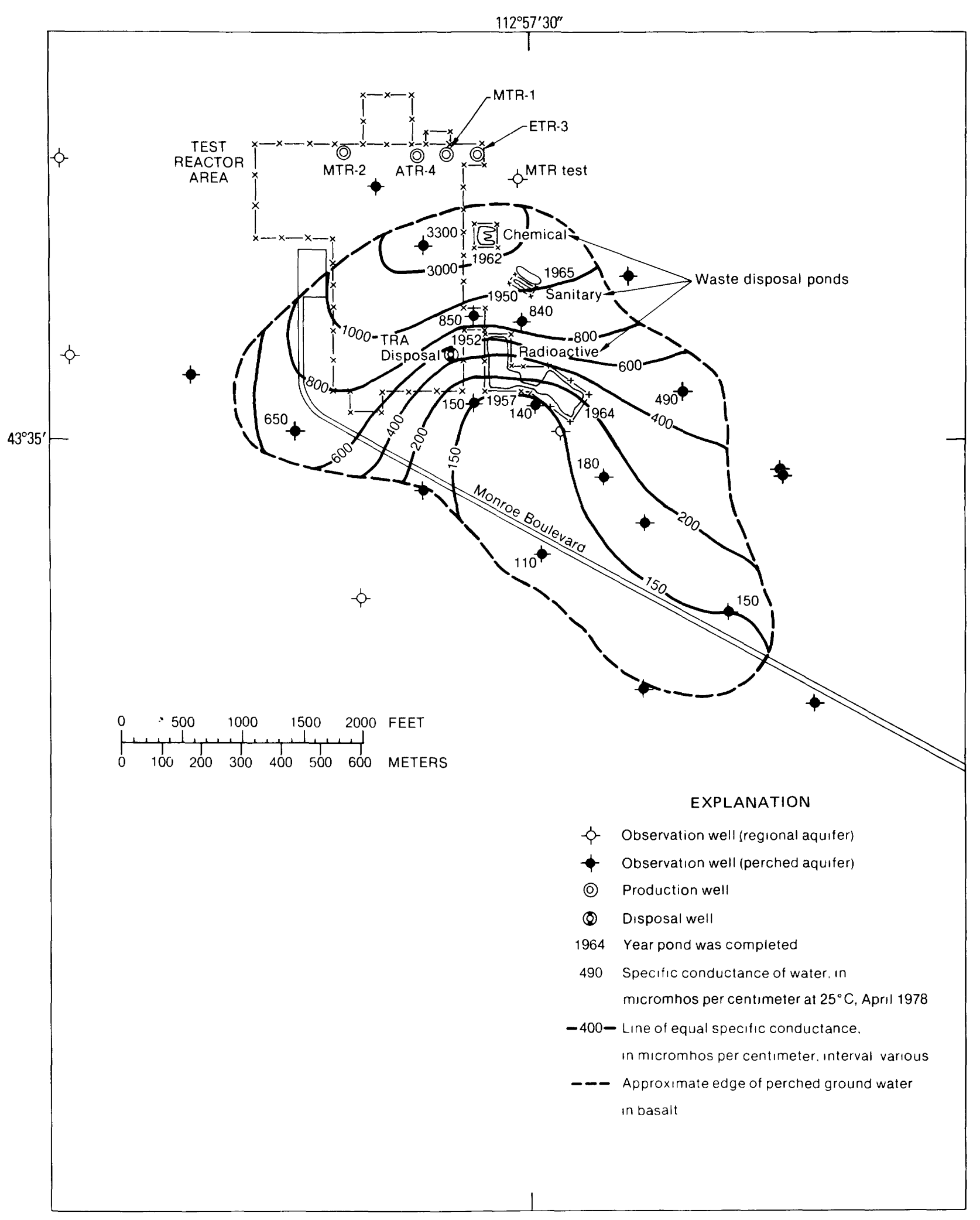

Figure 34. Specific conductance of samples from the perched ground water in the basalt at the TRA, April 1978. 
specific conductance as low as 110 micromhos per centimeter. As the waste water moves outward from the pond to the southwest, it becomes diluted by low specific conductance waste water from the large radioactive ponds.

\section{Sodium}

The sodium concentration in perched ground water in the basalt at TRA ranged from 4 to $148 \mathrm{mg} / \mathrm{L}$ in April 1978 (fig. 35). Highest values were measured in the northern part of the area where wells tap perched ground water near the chemical-waste disposal ponds. Concentrations decreased to the south and southeast because recharge received from the radioactive-waste disposal ponds dilute the perched waste water. Other chemical processes, such as ion exchange, also decrease the amount of sodium as it moves in solution through the geologic media.

\section{Total Chromium}

Chromium in the perched ground-water zone in the basalt beneath the TRA is derived principally from the radioactive-waste ponds. Figure 36 shows the distribution of the total chromium content in April 1975 at the TRA and shows that higher values occur in a southerly direction from the ponds. The anomalously high value in the southernmost portion of the perched-water area may be residual chromium in the perched aquifer from previous periods of higher chromium discharge which has not been flushed from the system. The amount of ground water moving through that particular area may have decreased over the past few years.

\section{Chloride}

Concentrations of chloride are generally higher in the northwest part of the basalt perched aquifer (fig. 37), proximal to the chemical-waste disposal pond, and decrease to the southeast because recharge from the radioactive-waste disposal ponds dilutes the underflowing perched ground water. The chloride concentrations of perched aquifer samples ranged from 3 to $113 \mathrm{mg} / \mathrm{L}$ in April 1977 (fig. 37). Concentrations of chloride in samples taken from the perched aquifer have decreased significantly from those reported for 1970 by Robertson, Schoen, and Barraclough (1974, p. 113). Waste water discharged to the chemical-waste ponds have contained negligible concentrations of chloride over the period 1974 to 1978.

\section{Sulfate}

The sulfate concentration is highest beneath the chemical-waste pond, probably because of the high concentration of sulfate in the waste water being discharged to the pond. Figure 38 shows the distribution of sulfate in the perched ground water at TRA in October 1975. The concentrations of sulfate in water from the perched aquifer ranged from 18 to $2,500 \mathrm{mg} / \mathrm{L}$ (fig. 38). Here again, the dilution effect of recharge to the perched aquifer from the radioactive waste disposal ponds is readily apparent by the decrease in sulfate concentration to the southeast.

\section{Snake River Plain Aquifer}

The distribution of the principal radioactive and nonradioactive-waste products in the Snake River Plain aquifer are discussed and illustrated in the following section; and the waste product concentrations are compared and contrasted, where applicable, to the natural quality of water in the regional aquifer. Olmsted (1962, p. 67-68) stated that the natural quality of water in the Snake River Plain aquifer in the INEL area could be divided into two general categories: a calcium, magnesium, bicarbonate, and carbonate dominated water underlying the western part of the INEL and reflecting the abundance of these constituents in the source areas, north and west of the INEL, which are underlain by limestone and dolomite; while a similar type of water underlies the eastern part of the site, it contains greater percentages of sodium and potassium, indicating that recharge to this portion of the aquifer originates in the mountains north and northeast of the INEL, an area underlain predominantly by silicic volcanic rocks. Analyses of water samples collected from the regional aquifer, in areas not affected by waste disposal, shows that these observations are correct.

The waste plumes south of ICPP have similar configurations and show corresponding decreasing concentrations downgradient from the discharge well. The waste plumes south of the TRA are not as well defined because of gaps in well coverage and because of dilution by recharge from the nearby Big Lost River. The lateral extents and dates of depiction are listed in table 4 for the detectable radiochemical and nonradiochemical waste plumes.

As in the section describing the perched water zone in the basalt underlying the TRA, depictions of waste products in the Snake River Plain aquifer would have preferably been done in a single time frame for comparative purposes; but this is not possible due to lack of a consistent time-correlative data base for each year and 


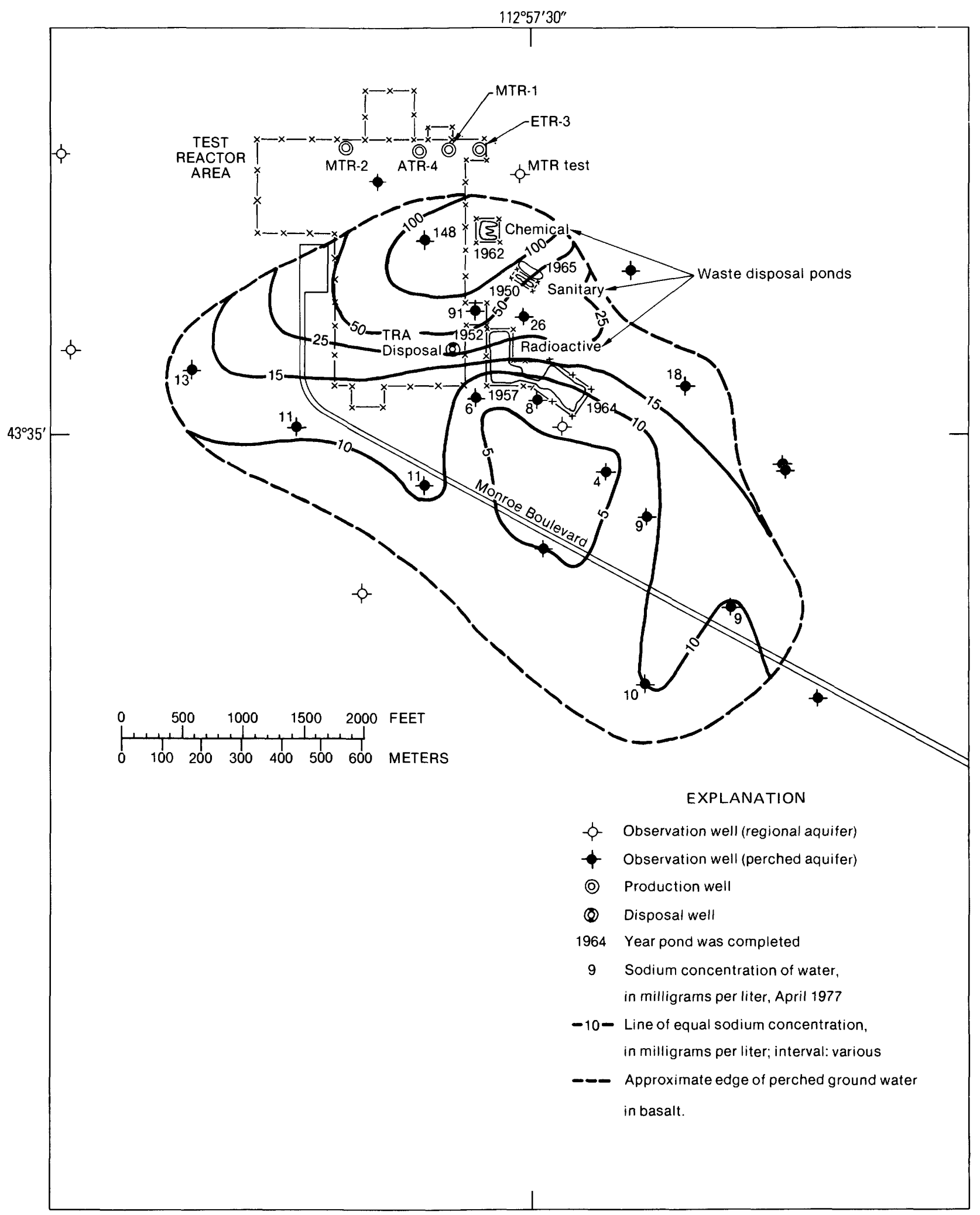

Figure 35. Concentration of sodium in the perched ground water in the basalt at the TRA, April 1977. 


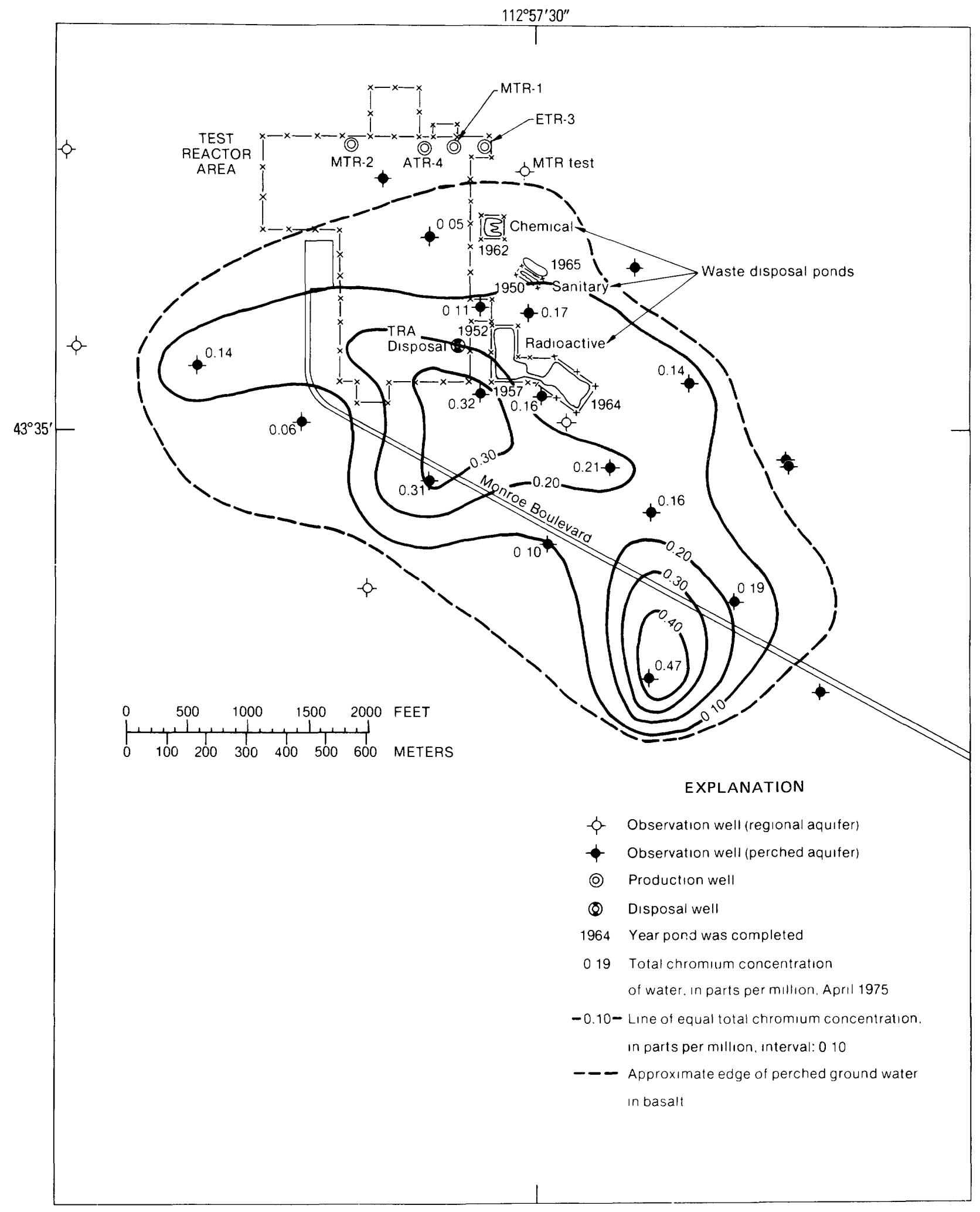

Figure 36. Total concentration of chromium in the perched ground water in the basalt at the TRA, April 1975. 


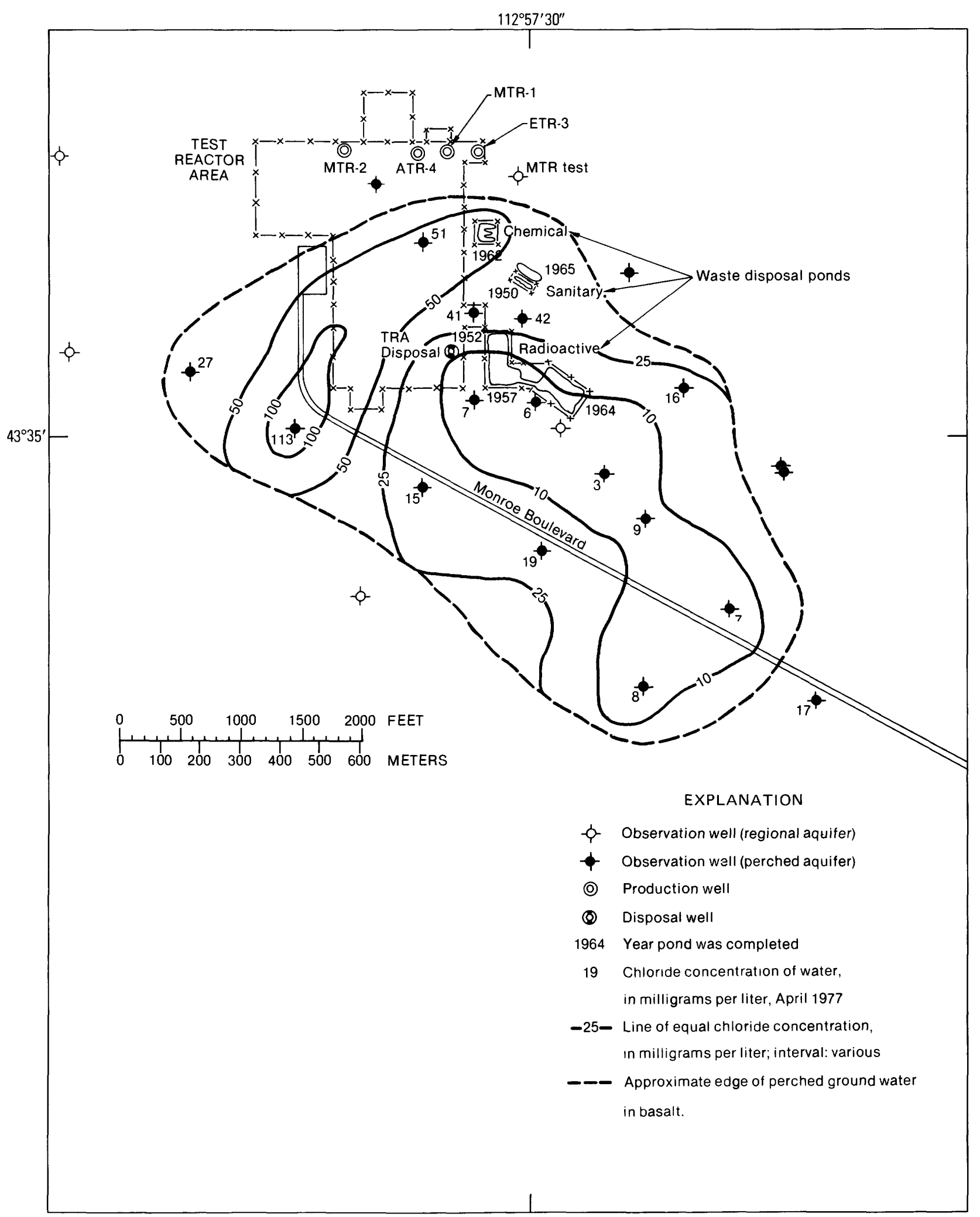

Figure 37. Concentration of chloride in the perched ground water in the basalt at the TRA, April 1977. 


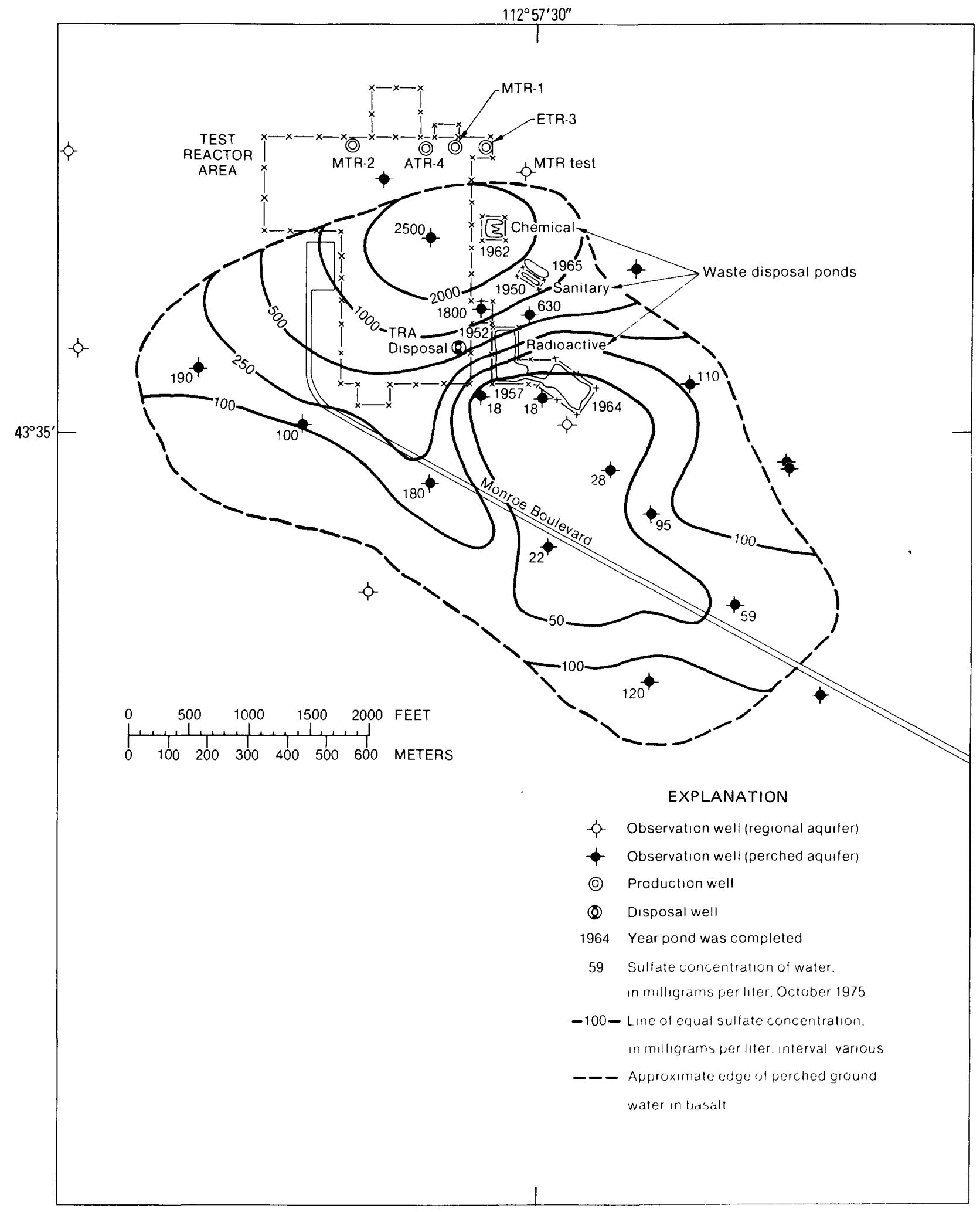

Figure 38. Concentration of sulfate in the perched ground water in the basalt at the TRA, October 1975. 
Table 4. Waste plumes in the Snake River Plain aquifer in the ICPP-TRA vicinity

\begin{tabular}{|c|c|c|c|c|}
\hline \multirow{2}{*}{$\begin{array}{l}\text { Waste } \\
\text { Plume }\end{array}$} & \multirow[b]{2}{*}{ Date } & \multicolumn{2}{|c|}{$\begin{array}{l}\text { Lateral waste migration } \\
\text { distance (in miles) from } \\
\end{array}$} & \multirow{2}{*}{$\begin{array}{l}\text { Area of waste } \\
\text { plume (in } \mathrm{mi}^{2}\end{array}$} \\
\hline & & ICPP Well & TRA Well & \\
\hline Tritium (H-3) & October 1978 & 7.5 & 7.5 & 28 \\
\hline Strontium-90 & April 1978 & 2.2 & 0 & 2.2 \\
\hline Iodine-129 & April 1977 & 2.2 & 0 & 2.8 \\
\hline Specific conductance & October 1978 & 4.3 & 5.6 & 18 \\
\hline Sodium & September 1977 & 4.2 & $?$ & 9.2 \\
\hline Chloride & September 1977 & 4.5 & 5.8 & 16.4 \\
\hline Nitrate & January 1979 & 3.5 & 1.0 & 8.7 \\
\hline
\end{tabular}

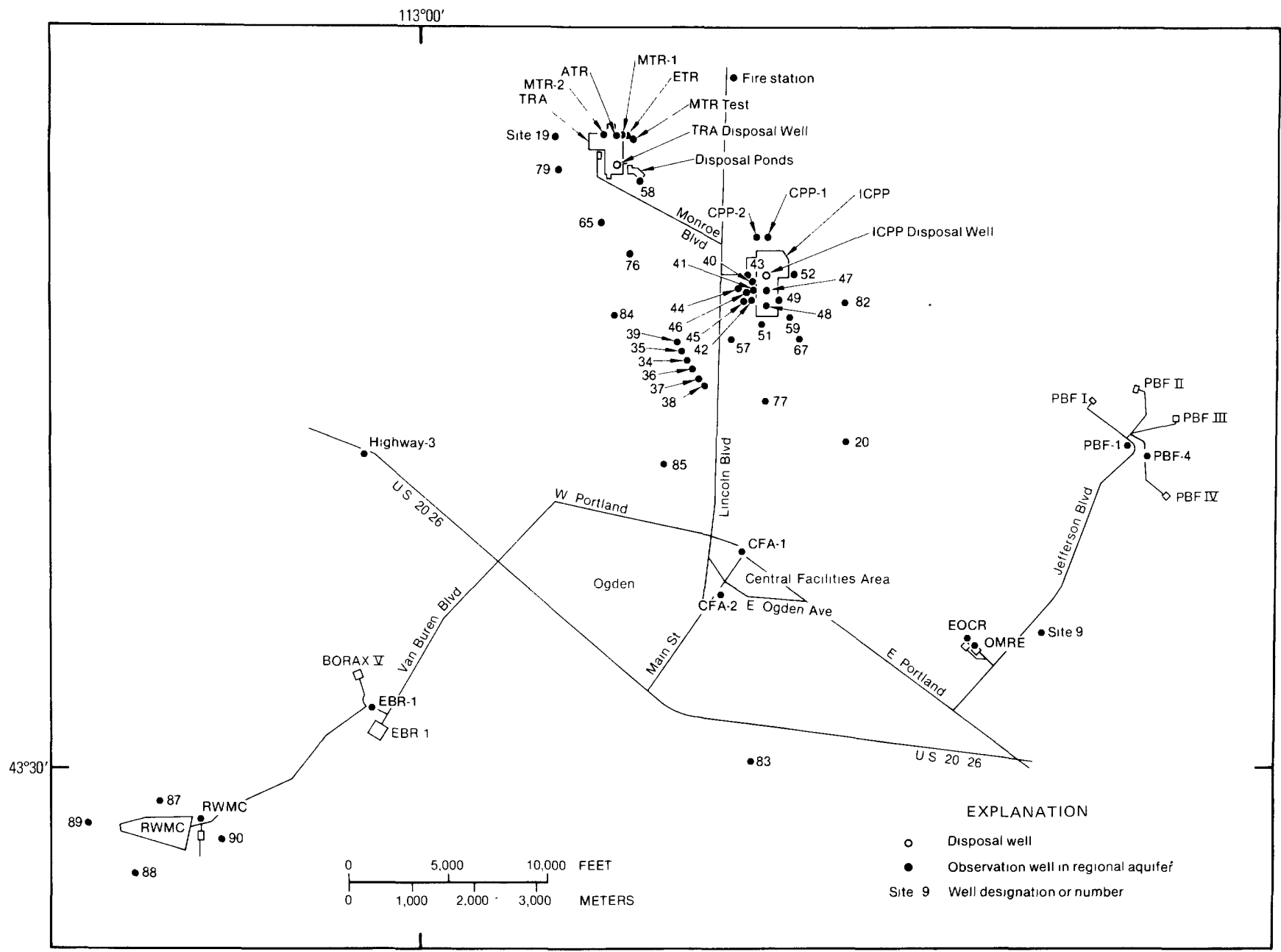

Figure 39. Location of observation wells completed in the Snake River Plain aquifer, waste disposal wells, and the radioactive waste disposal ponds in the ICPP-TRA vicinity.

waste product concentrations are therefore shown at varying times during the period 1974 through 1978. Figure 39 shows the areal location of observation wells completed in the regional aquifer, TRA disposal ponds, ICPP disposal well, various facilities, and other geographical features in the ICPP-TRA vicinity.

\section{Tritium}

The disposal of tritium at the ICPP has been monitored since December 1961. During the past seventeen years and a month, a total of about 7,680 Ci of tritium has been discharged at the ICPP and reaches the Snake River Plain aquifer directly through the deep disposal 
well or indirectly, prior to 1967 , by percolation of water discharged to a waste disposal pit. This represents an average disposal rate of nearly $427 \mathrm{Ci}$ per year. The rate of tritium disposal of $321 \mathrm{Ci}$ per year over the latest period of record, 1974 through 1978, was considerably less than the overall average. This injection into the regional aquifer of waste water, plus the simultaneous percolation of waste water from the perched ground-water zone underlying the TRA, has resulted in a large, dispersed plume of tritium in the regional ground-water system (fig. 40).

The October 1978 waste plume (fig. 40) illustrates the wide lateral dispersion and the preferred southward flow. The waste plume covers about $28 \mathrm{mi}^{2}$. The highest tritium values were found around the ICPP disposal well, south of the ICPP, and south of the disposal ponds at the TRA. Concentrations of tritium in water from the regional aquifer ranged from less than 0.2 to $204 \mathrm{pCi} / \mathrm{ml}$ in October 1978 (fig. 40). Tritium has migrated about 7.5 miles downgradient from the disposal well and ponds since disposal began. The arrival of tritium at the
Radioactive Waste Mangement Complex (RWMC) was first detected in 1975. The apparent velocity of tritium migration, based on first arrivals, from either the TRA radioactive-waste ponds or the ICPP disposal well ranges from 4 to 5 feet per day since the beginning of disposal operations in 1952 and 1953.

The decay of tritium in the Snake River Plain aquifer slightly exceeded the addition of tritium to the aquifer resulting from discharges during 1974 through 1976; thus the total quantity of tritium in the ground water declined during this period. The concentrations of tritium between ICPP and CFA increased over the next two years in response to increased tritium discharge through the ICPP disposal well during this period.

\section{Strontium-90}

A total of about $20 \mathrm{Ci}$ of strontium- 90 has been discharged to the ICPP well from 1952 through 1978. This is an average of 0.7 to $0.8 \mathrm{Ci}$ of strontium-90 per year. The current discharge of strontium-90 is somewhat less. For

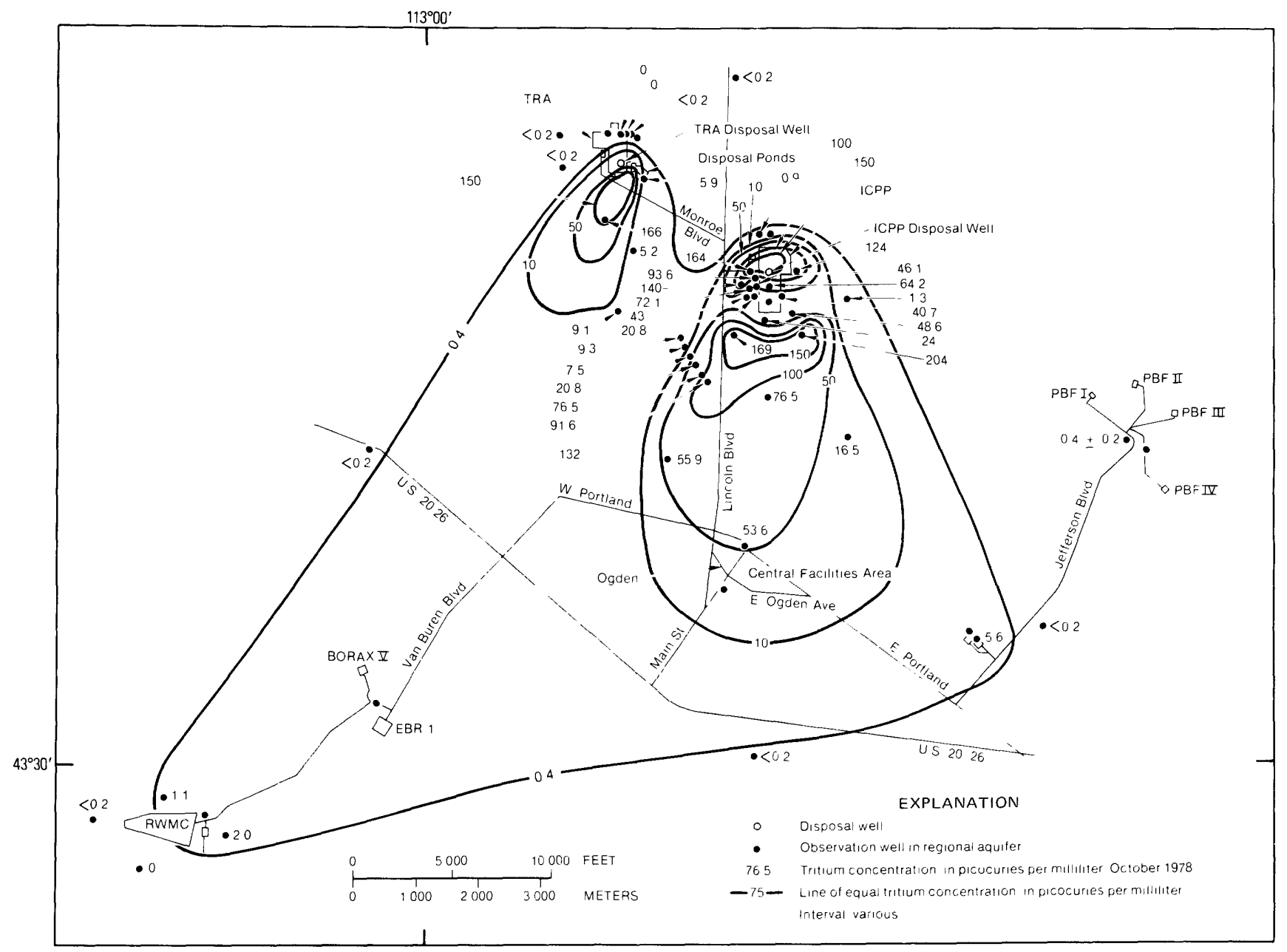

Figure 40. Distribution of tritium in the Snake River Plain aquifer, ICPP-TRA vicinity, October 1978. 
example, in 1974 a total of $0.2 \mathrm{Ci}$ was discharged to the ICPP well $(0.04$ percent of the total radioactivity discharged), whereas in 1978 a total of $0.7 \mathrm{Ci}$ of strontium90 was discharged to the ICPP well ( 0.2 percent of the total radioactivity discharged). From 1974 through 1978 a total of $2.0 \mathrm{Ci}$ of strontium-90 was discharged to the ICPP disposal well-an average of $0.4 \mathrm{Ci}$ per year.

Figure 41 shows the distribution of strontium-90 in the Snake River Plain aquifer in April 1978. The strontium- 90 plume covers about $2.2 \mathrm{mi}^{2}$ and has been detected less than 3 miles southwest of the disposal well at the ICPP. The size of the strontium-90 plume and concentrations of strontium-90 in the regional aquifer water samples have generally increased by only a slight amount since those depicted by Barraclough and Jensen (1976, p. 47).

\section{lodine-129}

An estimated 0.16 to $0.78 \mathrm{Ci}$ of iodine- 129 has been disposed of through the ICPP well from startup in 1952 through 1977 (Cordes, written commun., 1978). This is an average of about 0.01 to $0.03 \mathrm{Ci}$ of iodine-129 discharged per year. Actual monitoring of iodine-129 radioactivity in waste water was begun in May 1976. In 1977 a total of $0.02 \mathrm{Ci}$ was discharged to the ICPP well $(0.003$ percent of the total radioactivity discharged), and in $1978,0.14 \mathrm{Ci}$ of iodine-129 was discharged to the well ( 0.04 percent). These latter two years of documented discharge show that 1977 was within the estimated average discharge range, but during 1978 discharge was significantly greater than this approximated average. This discharge variance may be simply due to the differing operating procedures at the ICPP and does not indicate an actual increase in the discharge rate. For example, many of the waste producing components of the ICPP facility were not operating for much of 1977.

Concentrations of iodine-129 in sampled well water in April 1977 range from 0.9 to $27 \mathrm{pCi} / \mathrm{L}$ for statistically positive values (fig. 42) and are highest near the ICPP disposal well. Iodine-129 has migrated less than 3 miles from the ICPP disposal well since discharge began in 1953, but it will remain in this small portion of the aquifer for years to come because of its very long half-life of about 16.4 million years.

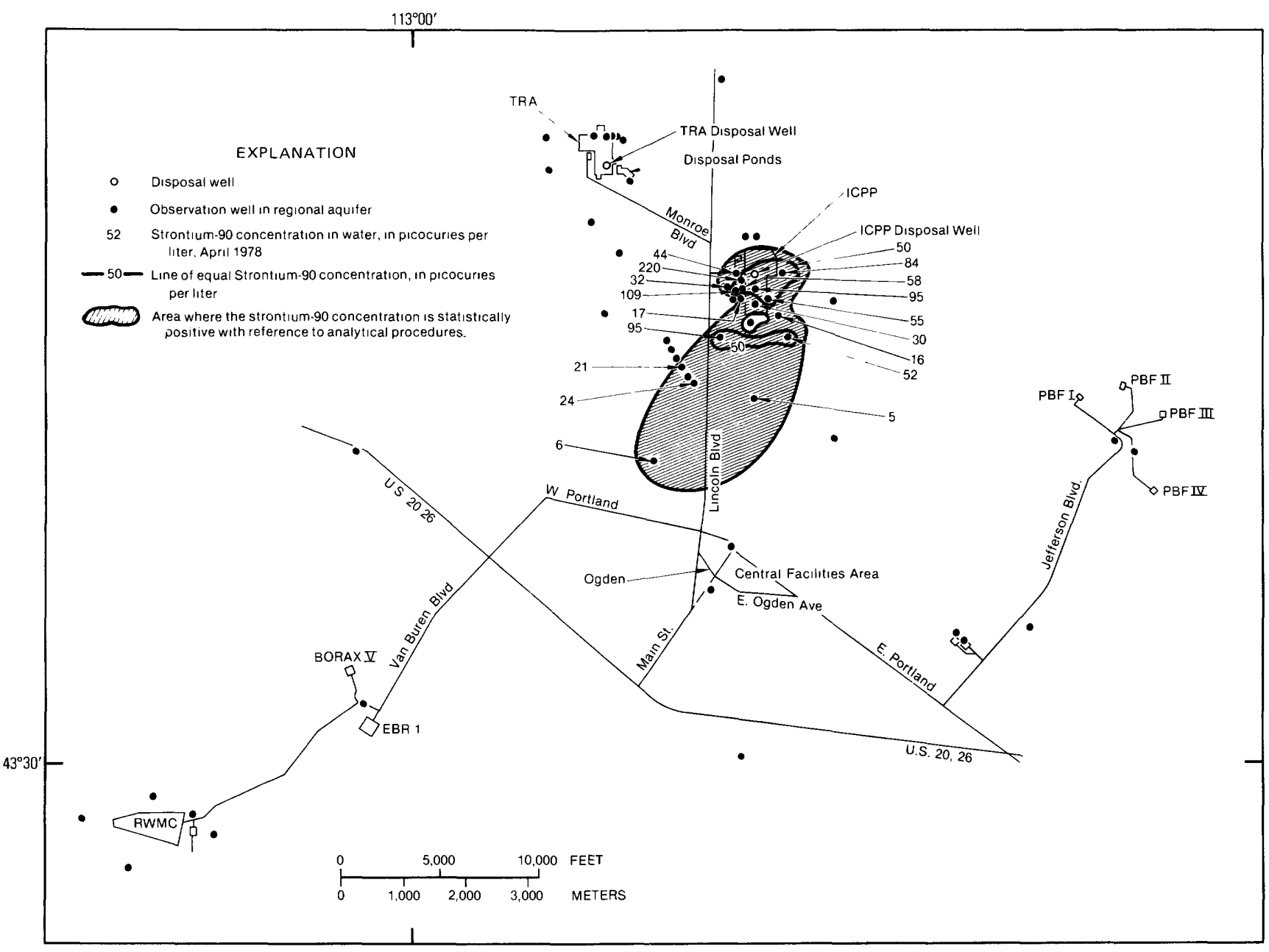

Figure 41. Distribution of strontium-90 in the Snake River Plain aquifer ICPP-TRA vicinity, April 1978. 


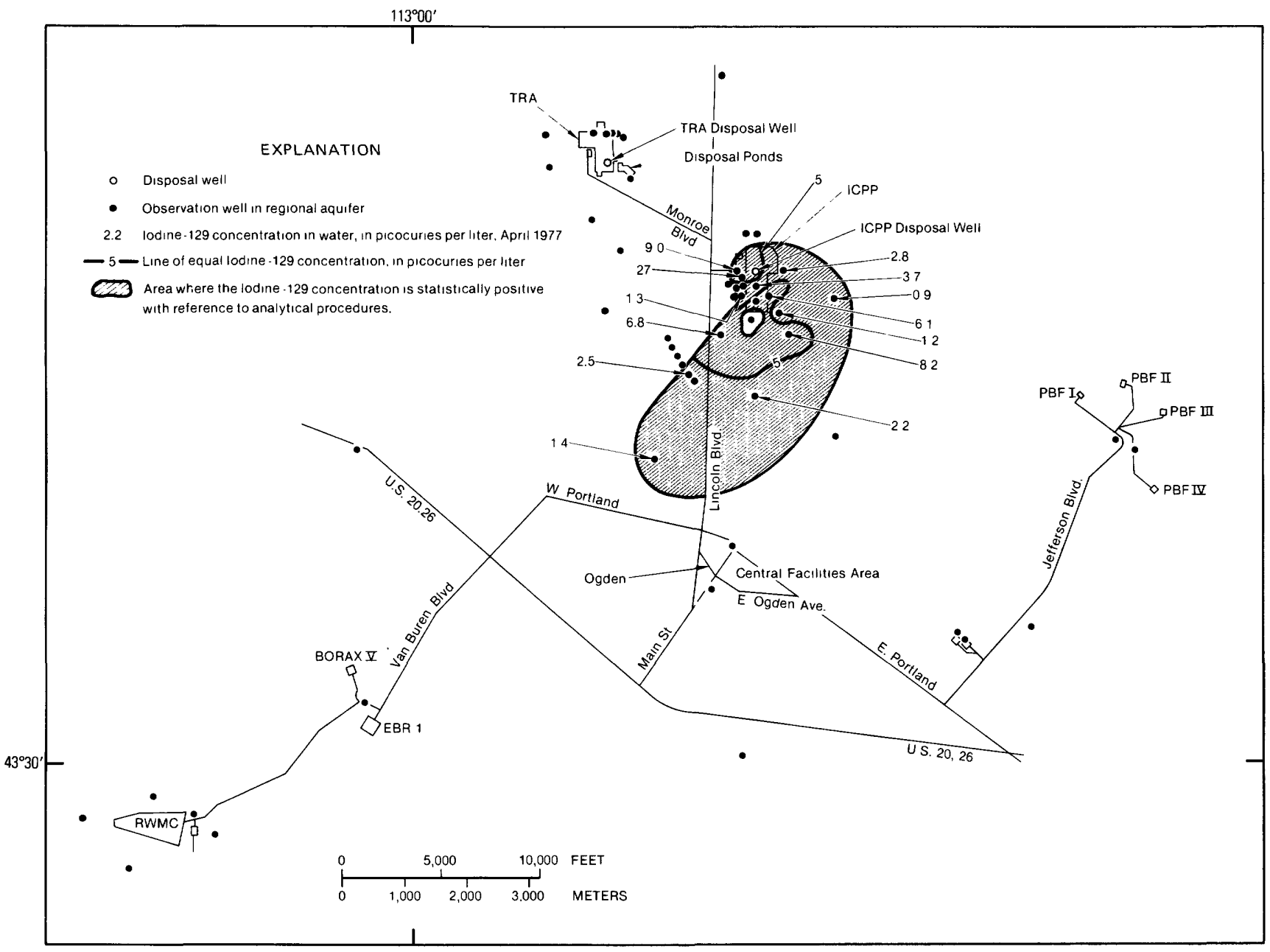

Figure 42. Distribution of iodine-129 in the Snake River Plain aquifer, ICPP-TRA vicinity, April 1977.

\section{Cesium-137}

About $20 \mathrm{Ci}$ of cesium-137 (similar to the quality of strontium-90) has been discharged to the ICPP disposal well. However, it is sorbed more readily than strontium-90 and has never been detected in any water samples from the regional aquifer near the ICPP and TRA. After 27 years of disposal, detectable quantities of cesium-137 have not reached the nearest observation well 700 feet from the ICPP disposal well.

\section{Plutonium Isotopes}

Monitoring of the plutonium-238 and of plutonium$239,-240$ (undivided) radionuclides being disposed of through the ICPP disposal well began in 1974. Prior to this time they were not separable in the undifferentiated alpha activity which was measured. From 1974 through 1978 a total of about $0.1 \mathrm{Ci}$ of plutonium-238 and $0.046 \mathrm{Ci}$ of plutonium-239-240 was discharged through the well. This represents a respective average discharge of $0.02 \mathrm{Ci}$ per year (0.006 percent of the total radioactivity discharged) and $0.009 \mathrm{Ci}$ per year ( 0.003 percent). Plutonium was disposed of in waste water which contained an average concentration of $0.016 \mathrm{pCi} / \mathrm{mL}$ of plutonium-238 and $0.007 \mathrm{pCi} / \mathrm{mL}$ of plutonium-239-240. The decay rates of plutonium-238, plutonium-239, and plutonium-240 are 89 years, 24,360 years and 6,600 years, respectively. This indicates that very small but detectable amounts of plutonium-239,-240 may remain in a limited portion of the regional aquifer for years to come regardless of future disposal practices.

Three consecutive monthly samples were taken from ground water in well 47 (fig. 39), located 740 feet south of the ICPP disposal well, from October through December of 1975 to evaluate the effects on the Snake River Plain aquifer by the disposal of wastes containing isotopes of plutonium. Several other wells were sampled but well 47 was the only one which contained statistically positive concentrations of the plutonium isotopes. Analysis of these samples determined that the concentration of the plutonium isotopes in the regional ground water is very 
low. The mean concentration of plutonium- 238 in the three samples from well 47 was $6.5 \times 10^{-6} \mathrm{pCi} / \mathrm{ml}$ (i.e. $0.0000065 \mathrm{pCi} / \mathrm{ml}$ ), and the mean value for plutonium$239,-240$ was $2.4 \times 10^{-6} \mathrm{pCi} / \mathrm{ml}$. These concentrations are approximately one to two million times lower than the Federal and State of Idaho concentration guides for unrestricted discharge (Polzer, Percival, and Barraclough, 1976). The concentrations of plutonium- 238 and plutonium-239-240 in the observation well samples are also several orders of magnitude lower than those for the same nuclides in the waste water being discharged through the disposal well. This concentration reduction over a relatively short distance is an indication of dilution, dispersion, and more importantly, removal of the soluble radioisotopes by sorption. Samples from well 47 were also analyzed for americium-241 but it was not detected. This is not an unexpected result because americium- 241 has not been detected in water discharged through the ICPP disposal well.

\section{Specific Conductance}

Chemical wastes are also discharged to the ICPP disposal well. From 1974 through 1978, these wastes contained, on an annual average, about $310,000 \mathrm{lbs}$ of sodium, 548,000 lbs of chloride, and $131,000 \mathrm{lbs}$ of nitrate. An average of 103,000 lbs of sulfate was disposed of per year except for 1976, when no sulfate disposal was reported. These chemical wastes increase the mineral content and, therefore, the specific conductance of the regional ground water. The specific conductance of ground water in the Snake River Plain aquifer containing no waste water usually ranges from 300 to $325 \mu \mathrm{mhos} / \mathrm{cm}$ in the ICPPTRA area (Robertson, Schoen, and Barraclough, 1974, p. 159). Waste water disposed through the ICPP disposal well and seepage from the TRA chemical waste disposal ponds have increased the specific conductance of the regional ground water significantly (fig. 43). The specific conductance plume extends south of CFA but has not

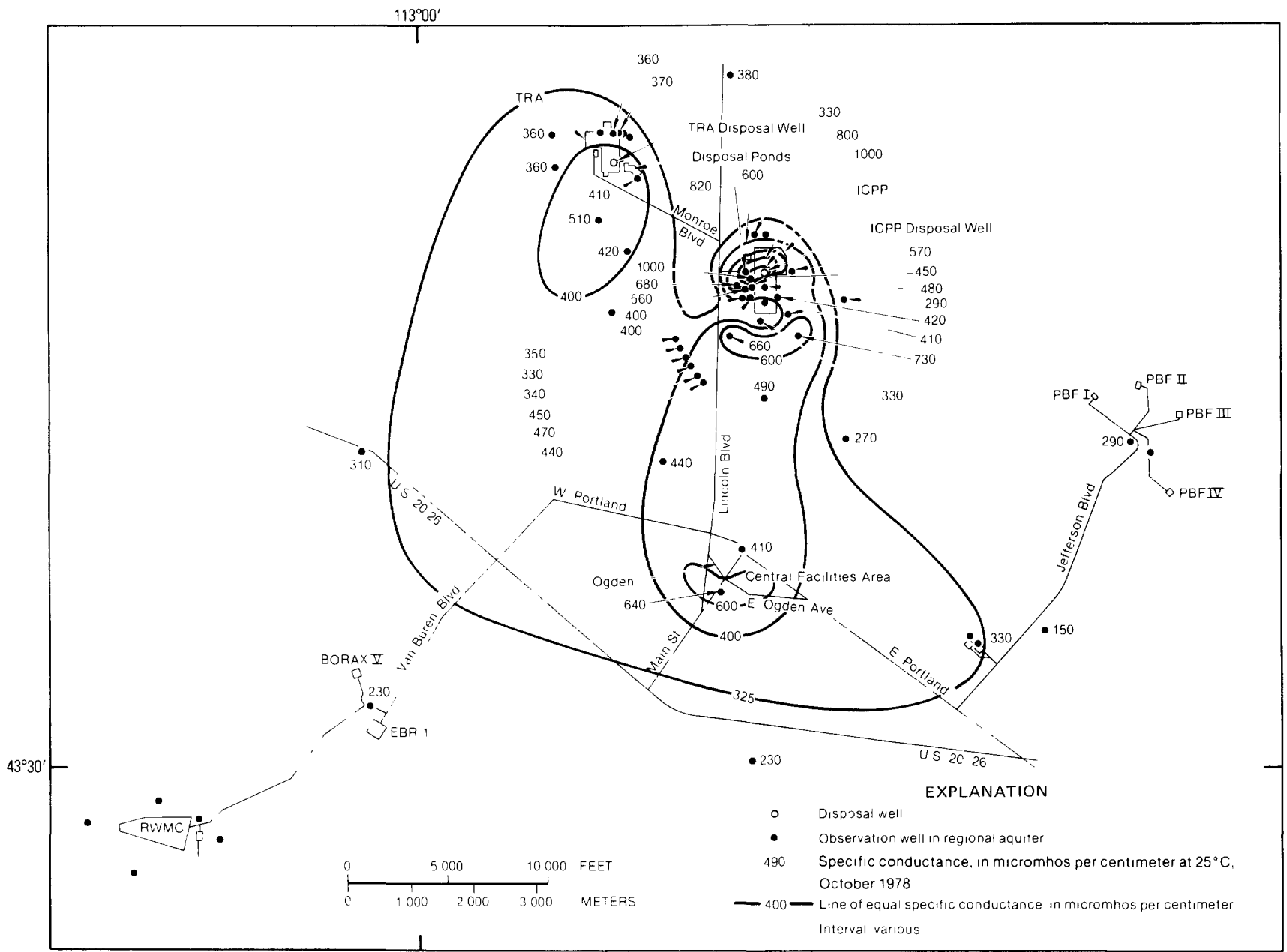

Figure 43. Specific conductance of samples from the Snake River Plain aquifer, ICPP-TRA vicinity, October 1978. 
changed a great deal since October 1972, as shown by Barraclough and Jensen (1976, p. 48). Values within the plume boundaries have generally increased only slightly over the past few years.

\section{Sodium}

The rate of discharge of sodium to the ICPP disposal well has been rather uniform over the years. The average concentration of sodium in the waste water is about 102 $\mathrm{mg} / \mathrm{L}$. The background or normal concentration of sodium in water from the Snake River Plain aquifer is 8 to $10 \mathrm{mg} /$ L. Figure 44 shows the concentration of sodium in well water and the area covered by the waste plume in September 1977. Average concentrations are nearly the same as those published for October 1972 (Barraclough and Jensen, 1976, p. 49), but the size of the waste plume has decreased slightly since that time. This may in part be due to the fact that the average concentration of sodium in effluent waste water of $88 \mathrm{mg} / \mathrm{L}$ from 1974 through 1976 , is 14 percent lower than the average concentration (102 $\mathrm{mg} / \mathrm{L}$ ) over the entire period of record. The effect of sorption, ion exchange, or other chemical reactions on the migration of sodium is shown in figure 44; as water migrates downward from the TRA ponds, most of the sodium is apparently removed by these chemical reactions.

\section{Total Chromium}

As stated previously, chromium was being discharged directly to the Snake River Plain aquifer via the TRA deep disposal well from 1964 to 1972 . Since 1972, a different corrosion inhibiting process has been employed which utilizes no chromium compound. Chromium has also been discharged to the TRA radioactive-waste ponds in the past, and is present in the underlying perched ground water in the basalt (fig. 36). The total chromium

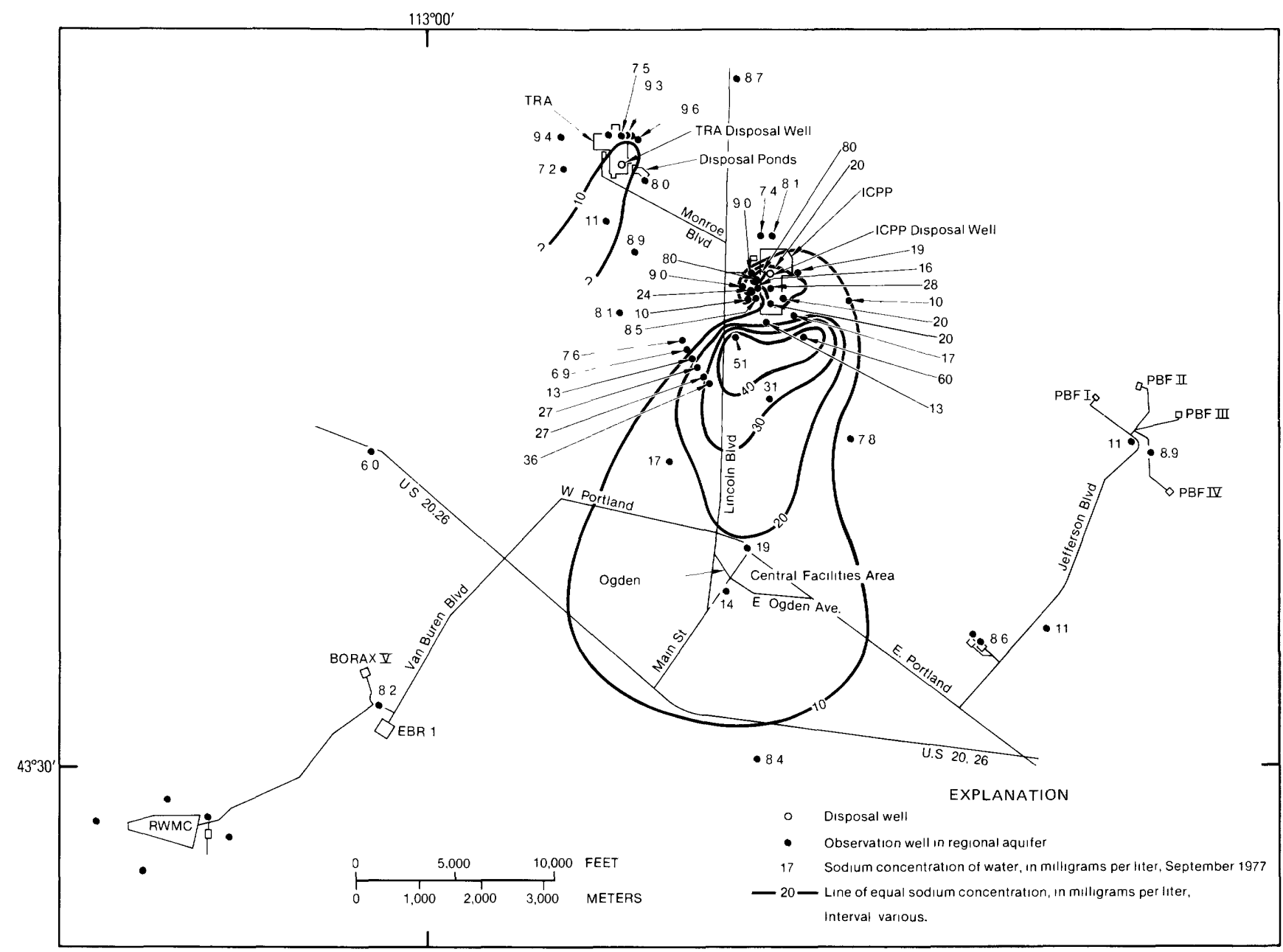

Figure 44. Distribution of waste sodium in the Snake River Plain aquifer, ICPP-TRA vicinity, September 1977. 
content of the regional ground water was augmented by the direct disposal of waste water, prior to 1972, and by percolation from the overlying perched zone. Well number 65 , located approximately 1,500 feet south of the TRA facility (fig. 39), is the only well which taps the regional aquifer that contained water with statistically positive total chromium concentrations for the period 1974 through 1978. Quarterly samples of water from well 65 over the latest period of record contained an average total chromium concentration of about $0.33 \mathrm{mg} / \mathrm{L}$, and the values show very little variance.

\section{Chloride}

The average concentration of waste chloride disposed of through the ICPP well, from 1974 through 1978, was $179 \mathrm{mg} / \mathrm{L}$. The background or normal concentration of chloride in the Snake River Plain aquifer in the TRA-ICPP vicinity is usually 8 and $15 \mathrm{mg} / \mathrm{L}$. As a matter of interest, the Idaho Drinking Water Standards (1977) set the secondary quality standard for chloride concentration of drink- ing water at $250 \mathrm{mg} / \mathrm{L}$. This concentration limit is based primarily on taste.

Figure 45 shows the distribution of waste chloride in the Snake River Plain aquifer in September 1977. The highest chloride values are found around the ICPP disposal well and south of the ICPP. In a few cases, the concentration of waste chloride in the regional groundwater samples has increased by as much as 40 percent during the period from 1974 to 1978 . This increase is probably caused by a significant increase in the amount of chloride being disposed of through the ICPP well. For example, from 1971 through 1973 an average of 386,000 lbs of chloride per year was discharged; whereas during the period 1974 through 1978 , the average yearly discharge was $548,000 \mathrm{lbs}$.

\section{Sulfate}

The average concentration of sulfate in the waste water disposed of through the ICPP well, from 1974 through 1978, was about $32 \mathrm{mg} / \mathrm{L}$ with the exception of

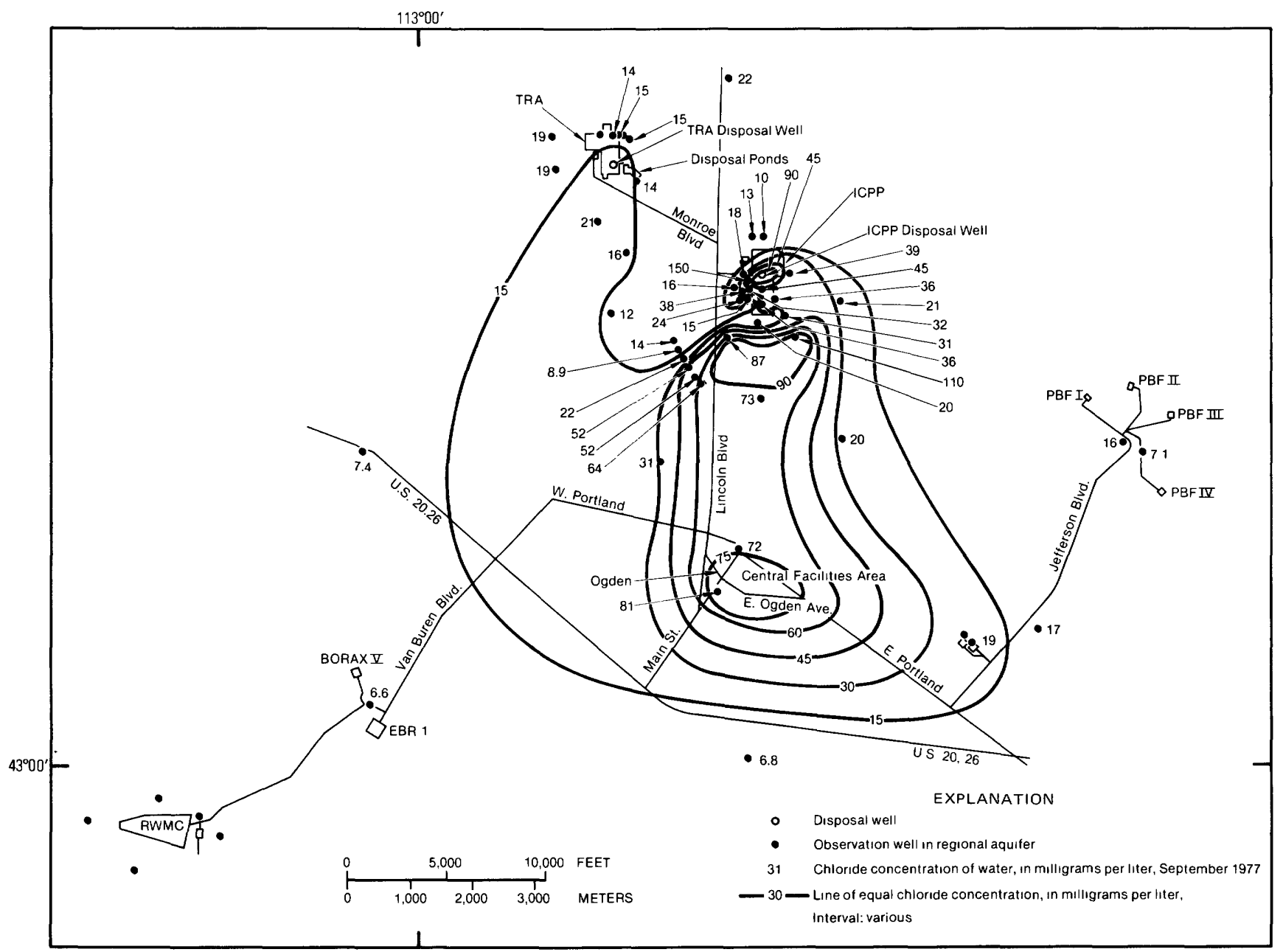

Figure 45. Distribution of waste chloride in the Snake River Plain aquifer, ICPP-TRA vicinity, September 1977. 
1976 when no sulfate disposal was reported. At the TRA deep disposal well, the yearly average concentration of sulfate was $196 \mathrm{mg} / \mathrm{L}$ for the entire five-year period. The background concentration of sulfate in the Snake River Plain aquifer is usually less than about 20 to $25 \mathrm{mg} / \mathrm{L}$. A sulfate waste plume was not mapped because the only water samples above the normal level are adjacent to and immediately south of the ICPP disposal well and south of the TRA deep disposal well (fig. 39). The area south of the TRA is the largest area affected, with a measured value slightly above normal being recorded 1.3 miles from the facility. This small plume is a result of waste sulfate disposed through the deep well and of recharge from the overlying perched aquifer in the basalt.

\section{Nitrate}

Waste water containing nitrate has been disposed of through the ICPP well since 1952, but 1973 was the first year in which the concentration in waste water was reported. During that year, the average waste nitrate concen- tration entering the Snake River Plain aquifer was $39 \mathrm{mg} / \mathrm{L}$ (calculated as $\mathrm{NO}_{3}^{-}$). Over the next five years this average increased slightly to $40 \mathrm{mg} / \mathrm{L}$, but it increased to $47 \mathrm{mg} / \mathrm{L}$ in 1977 and to $80 \mathrm{mg} / \mathrm{L}$ during 1978 . The normal or background level of nitrate in the regional ground water is usually less than $5 \mathrm{mg} / \mathrm{L}$.

The first recent comprehensive sampling of the observation wells in the regional aquifer for nitrate analyses, was completed in January 1979. Figure 46 shows the effects of the increased disposal of nitrate during 1977 and 1978 on the regional aquifer. A large waste plume, containing values greater than $5 \mathrm{mg} / \mathrm{L}$, covers an area of about $8.7 \mathrm{mi}^{2}$ and is elongated to the south of the ICPP disposal well.

\section{SUMMARY}

This report describes the effect of the disposal of liquid radioactive and chemical wastes on the quality of the water in the Snake River Plain aquifer at the Idaho Na-

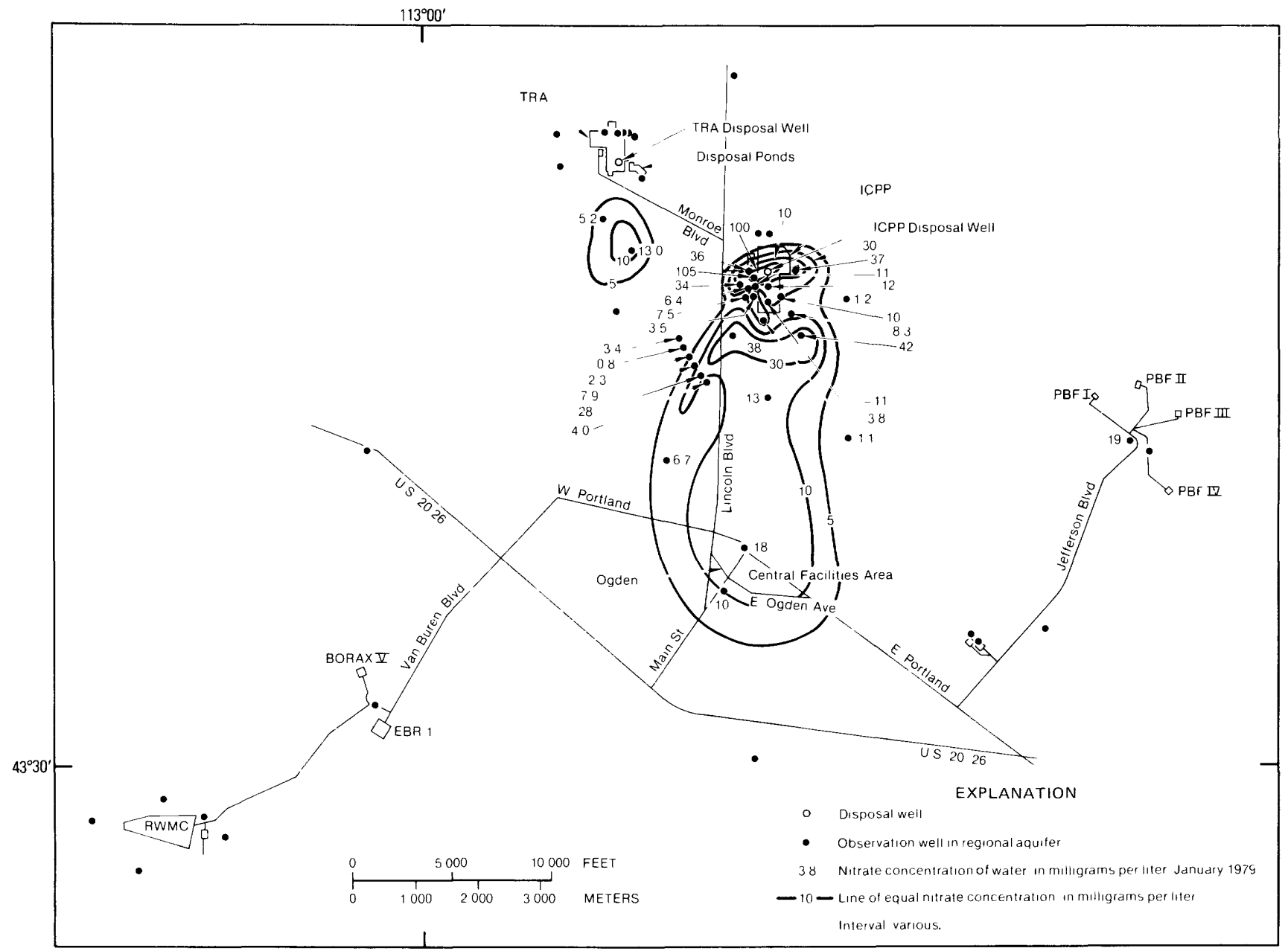

Figure 46. Distribution of waste nitrate in the Snake River Plain aquifer, ICPP-TRA vicinity, January 1979. 
tional Engineering Laboratory (INEL). The report covers the period following that summarized in a report by Robertson, Schoen, and Barraclough (1974), which discussed the influence of waste disposal at the INEL from 1952 to 1970 , and in a report by Barraclough and Jensen (1976), which summarizes the influence of waste disposal from 1971 to 1973 on the water quality of the Snake River Plain aquifer.

Ground-water samples were collected to determine the concentration and the migration of radioactive wastes in the subsurface. An average of 223 water samples was collected annually from 1974 to 1978 , and an average of 1,506 chemical and radiometric determinations was made annually. An annual average of 768 water-level measurements was made in wells to determine the relationship of waste movement to water-level fluctuations. Water-level fluctuations within both the regional and perched water systems were monitored and mapped.

The altitude of the regional water table at the INEL ranges from 4,584 feet above the vertical geodetic datum in the north to 4,426 feet in the southwest. The average water-table gradient is about 4 feet per mile to the southsouthwest. Within the INEL boundaries the depth to the regional water table ranges from about 200 feet below land surface in the northeast to more than 1,000 feet in the southeast. The net decline of the water table from July 1972 to July 1978 has ranged from as little as 0.2 foot near the north boundary to the INEL to more than 10 feet in its central and southern parts.

Twenty-five INEL production wells pumped 2.5 billion gallons of water per year from 1974 to 1978 , for an average of 6.9 million gallons per day. About 60 percent of this pumpage was returned to the aquifer.

The Big Lost River brings considerable surface water onto the INEL during wet years. Recharge to the Snake River Plain aquifer from this flow has been significant. The average flow of the Big Lost River below Mackay Reservoir, from 1965 to 1976 , has been the highest for the entire period of record. The six years with the highest annual discharge of record were 1965, 1969, 1967, 1974, 1975, and 1971, in order of decreasing discharge. Little or no flow was recorded at two gaging stations on the INEL in 1977 and 1978.

Recharge from the Big Lost River and other streams, to the north of the INEL, caused the water table in the aquifer to rise to record highs in 1972, 1973, or 1974 over much of the INEL. The water level in one well rose 21.5 feet from 1964 to 1972. This is the largest fluctuation in water level in the Snake River Plain aquifer that has been observed at the INEL. Water levels have declined, in many of the observation wells which penetrate the regional aquifer, from the record high levels of 1972, to near-record and record lows by the end of 1978 .

The Test Reactor Area (TRA) utilizes ponds and a deep well to dispose of about 470 million gallons of dilute waste water per year for 1974 through 1978. More than 40 percent of the liquid waste is discharged to radioactivewaste ponds. Infiltration from the ponds has formed a large perched-water zone in the underlying basalt. The perched ground-water zone contains tritium, chromium51 , cobalt- 60 , strontium- 90 , and several nonradioactive chemicals. The extent and concentration of the radionuclides in the perched ground water has remained relatively constant or has decreased slightly during 1974 to 1978 with few exceptions. Concentrations of cobalt- 60 and the affected area have increased, probably because the slow decay rate of this nuclide causes it to remain in the system over a longer period of time. Concentrations of strontium-90 have also increased over the last five years but the size of the affected area has not increased because sorptive reactions with aquifer matrix material removes the radioisotope from solution near the leading edge of the contaminated area.

The Idaho Chemical Processing Plant (ICPP) discharges low-level radioactive waste and chemical waste directly to the Snake River Plain aquifer through a disposal well 600 feet deep. Most of the radioactivity is removed by distillation and ion exchange prior to discharge of the waste into the well. During 1974 to 1978 the well was used to dispose of $1,697 \mathrm{Ci}$ of radioactivity, of which $1,605 \mathrm{Ci}$ was as tritium ( 95 percent). The average yearly discharge was about 372 million gallons of waste water.

Radionuclides are subject to radioactive decay, sorption, and dilution by dispersion in the regional aquifer. Chemical wastes are subject to sorption and dilution by dispersion. Waste plumes south of the ICPP containing tritium, sodium, chloride, and nitrate have been mapped and all have similar configurations. The plumes follow generally southerly flow lines and are laterally dispersed in that portion of the aquifer underlying the INEL.

Tritium is distributed in the Snake River Plain aquifer over about 28 square miles. Since disposal began in 1952, tritium has migrated about 7.5 miles downgradient from discharge points.

The waste plumes of strontium- 90 and iodine- 129 cover much smaller areas of the regional aquifer, about 2.2 and 2.8 square miles respectively. Based on the relatively small size of the plume, it would appear that the strontium-90 is sorbed from solution as it moves through the Snake River Plain aquifer. The iodine-129 plume also covers a relatively small area but is in response to very low discharge quantities. Cesium-137 has been discharged in quantities similar to those of strontium- 90 but has not been detected in the perched-water zone or in water from the Snake River Plain aquifer. Cesium-137 is strongly sorbed to the minerals in the alluvial sediments, basalt, and clay-to-silt interbeds.

Detectable plutonium radioisotopes and total 
chromium concentrations have been found in only two wells which penetrate the Snake River Plain aquifer. Plutonium-238 and plutonium-239,-240 were detectable in well 47 south of the ICPP but in very minute quantities. Total chromium concentrations were measurable in well 65 south of the TRA in concentrations very consistent on a yearly basis.

\section{SELECTED REFERENCES}

Barraclough, J. T., and Jensen, R. G., 1976, Hydroligic data for the Idaho National Engineering Laboratory site, Idaho, 1971 to 1973: U.S. Geological Survey Open-File Repot 75-318 (IDO-22055), $52 \mathrm{p}$.

Barraclough, J. T., Robertson, J. B., and Janzer, V. J., 1976, Hydrology of the solid waste burial ground, as related to the potential migration of radionuclides, Idaho National Engineering Laboratory, with a section on Drilling and sample Drilling and sample analyses, by L. G. Saindon: U.S. Geological Survey Open-File Report 76-471 (IDO-22056), $183 \mathrm{p}$.

Barraclough, J. T., Teasdale, W. E., and Jensen, R. G., 1967, Hydrology of the National Reactor Testing Station, Idaho, 1965: U.S. Geological Survey Open-File Report IDO22047, $107 \mathrm{p}$.

Barraclough, J. T., Teasdale, W. E., Robertson, J. B., and Jensen, R. G., 1967, Hydrology of the National Teactor Testing Station, Idaho, 1966: U.S. Geological Survey Open-File Report IDO-22048, 95 p.

Cordes, O. L., 1978, I-129 in liquid and airborne effluents: Allied Chemical Corporation, Idaho Chemical Programs-Operations Office, Idaho Falls, Idaho, unpublished letter Cord53-58, 5 p.

Druffel, Leroy, Stiltner, G. J., and Keefer, T. N., 1979, Probable hydrologci effects of a hypothetical failure of Mackay Dam on the Big Lost River valley from Mackay, Idaho, to the Idaho National engineering Laboratory: U.S. Geological Survey Water-Resources Investigations 79-99 (IDO22058), 47 p.

Humphrey, T. G., and Tingey, F. H., 1978, The subsurface migration of radionuclides at the Radioactive Waste Management Complex, 1976-1977: U.S. Department of Energy, Idaho Operations Office Publication, TREE-1171, 98 p.

1975c, Idaho National Engineering Laboratory industrial waste management information for 1974 and record-to-date: U.S. Atomic Energy Commission, Office of Waste Management, Idaho Operations Office Publication, IDO-10057 (74), $69 \mathrm{p}$.

1976a, Idaho National Engineering Laboratory radioactive waste management information, 1975 summary and record-to-date: U.S. Energy Research and Development Administration, Office of Waste Management, Idaho Operations Office Publication, IDO-10054 (75), $50 \mathrm{p}$.

1976b, Idaho National Engineering Laboratory radioactive waste management information for 1975: U.S. Energy Research and Development Administration, Office of Waste
Management, Idaho Operations Office Publication, IDO1055 (75), $250 \mathrm{p}$.

Morris D. A., Barraclough, J. T., Hogenson, G. M., Shuter, Eugene, Teasdale, W. E., Ralston, D. A., and Jensen, R. G., 1964, Hydrology of subsurface waste disposal, National Reactor Testing Station, Idaho, annual progress report, 1963: U.S. Atomic Energy Commission, Idaho Operations Office Publication, IDO-22046-USGS, 97 p.

Morris, D. A., Hogenson, G. M., Shuter, Eugene, and Teasdale, W. E., 1963, Hydrology of waste disposal, National Reactor Testing Station, Idaho, annual progress report, 1962: U.S. Atomic Energy Commission, Idaho Operations Office Publication, IDO-22044-USGS, 99 p.

Mundorff, M. J., Crosthwaite, E. G., and Kilburn, Chabot, 1964, Ground water for irrigation in the Snake River Basin in Idaho: U.S. Geological Survey Water-Supply Paper $1654,224 \mathrm{p}$.

Olmsted, F. H., 1962, Chemical and physical character of ground water in the National Reactor Testing Station, Idaho: U.S. Atomic Energy Commission, Idaho Operations Office Publication, IDO-22043-USGS, 142 p.

Polzer, W. L., Percival, D. R., and Barraclough, J. T., 1976, Special analyses for Plutonium and Americium in water from the Snake River Plain aquifer: U.S. Department of Energy, Idaho Operations Office Publication, IDO-12081, $9 \mathrm{p}$.

Robertson, J. B., 1974, Digital modeling of radioactive and chemical waste transport in the Snake River Plain aquifer at the National Reactor Testing Station, Idaho: U.S. Geological Survey Open-File Report IDO-22054, 41 p.

1977, Numerical modeling of subsurface radioactive solute transport from waste-seepage ponds at the Idaho National Engineering Laboratory: U.S. Geological Survey Open-File Report 76-717 (IDO-22057), 68 p.

Robertson, J. B., Schoen, Robert, and Barraclough, J. T., 1974, The influence of liquid waste disposal on the geochemistry of water at the National Reactor Testing Station, Idaho, 1952-1970: U.S. Geological Survey Open-File Report IDO22053, $231 \mathrm{p}$.

U.S. Environmental Protection Agency, 1976, National interim primary drinking water regulations: U.S. Environmental Protection Agency, Office of Water Supply Publication, EPA-570/9-76-003, 159 p.

Waste Management Programs, EG\&G Idaho, Inc., 1979a, Idaho National Engineering Laboratory radioactive waste management information, 1978 summary and record-to-date: U.S. Department of Energy, Nuclear Fuel Cycle Division, Idaho Operations Office Publication, IDO-10054 (78), 57 p.

1979b, Idaho National Engineering Laboratory radioactive waste management information for 1978: U.S. Department of Energy, Nuclear Fuel Cycle Division, Idaho Operations Office Publication, IDO-10055 (78), 290 p.

-1979c, Idaho National Engineering Laboratory industrial waste management information for 1978 and record-to-date: U.S. Department of Energy, Nuclear Fule Cycle Division, Idaho Operations Office Publication, IDO-10057 (78), 74 p.

White, S. S., compiler, 1975a, Idaho National Engineering Laboratory radioactive waste management information, 1974 
summary and record-to-date: U.S. Atomic Energy Commission, Office of Waste Management, Idaho Operations Office Publication, IDO-10054 (74), 22 p.

-1975b, Idaho National Engineering Laboratory radioactive waste management information for 1974: U.S. Atomic Energy Commission, Office of Waste Management, Idaho Operations Office Publication, 1DO-10055 (74), 198 p.

1976c, Idaho National Engineering Laboratory industrial waste management information for 1975 and record-to-date: U.S. Energy Research and Development Administration, Office of Waste Mangement, Idaho Operations Office Publication, IDO-10057 (75), $75 \mathrm{p}$.

1977a, Idaho National Engineering Laboratory radioactive waste management information, 1976 summary and record-to-date: U.S. Energy Research and Development Administration, Office of Waste Management, Idaho Operations Office Publication, IDO-10054 (76), 54 p.

1977b, Idaho National Engineering Laboratory radioactive waste management information for 1976: U.S. Energy Research and Development Administration, Office of Waste Management, Idaho Operations Office Publication, IDO10055 (76), $287 \mathrm{p}$.

1977c, Idaho National Engineering Laboratory industrial waste management information for 1976 and record-to-date: U.S.' Energy Research and Development Administrtion, Office of Waste Management, Idaho Operations Office Publication, IDO-10057 (76), 79 p.

1978a, Idaho National Engineering Laboratory radioactive waste management information, 1977 summary and re- cord-to-date: U.S. Department of Energy, Nuclear Fuel Cycle Division, Idaho Operations Office Publication, 1DO10054 (77), $53 \mathrm{p}$.

1978b, Idaho National Engineering Laboratory radioactive waste management information for 1977: U.S. Department of Energy, Nuclear Fuel Cycle Division, Idaho Operations Office Publication, IDO-10055 (77), 289 p.

1978c, Idaho National Engineering Laboratory industrial waste management information for 1977 and record-to-date: U.S. Department of Energy, NuclearFuel Cycle Division, Idaho Operations Office Publication, IDO-10057 (77), 74 p.

Idaho Department of Health and Welfare, 1977, Idaho regulations for public drinking water systems: Idaho Department of Health and Welfare, Division of Environment Publication, Title 1, Chapter 8, $44 \mathrm{p}$.

Jones, P. H., 1961, Hydrology of waste disposal, National Reactor Testing Station, Idaho, and interim report: U.S. Atomic Energy Commission, Idaho Operations Office Publication, IDO-22042-USGS, $152 \mathrm{p}$.

Lamke, R. D., 1969, Stage-discharge relations on Big Lost River, within National Reactor Testing Station, Idaho: U.S. Geological Survey Open-File Report IDO-22050, 29 p.

Morris, D. A., Barraclough, J. T., Chase, G. H., Teasdale, W. E., and Jensen, R. G., 1965, Hydrology of subsurface waste disposal, National Reactor Testing Station, Idaho, annual progress report, 1964: U.S. Atomic Energy Commission, Idaho Operations Office Publication, IDO-22047USGS, $186 \mathrm{p}$. 